\title{
Movilización intracelular de colesterol mediada por apolipoproteína A-I y dHDL: dominios proteicos involucrados
}

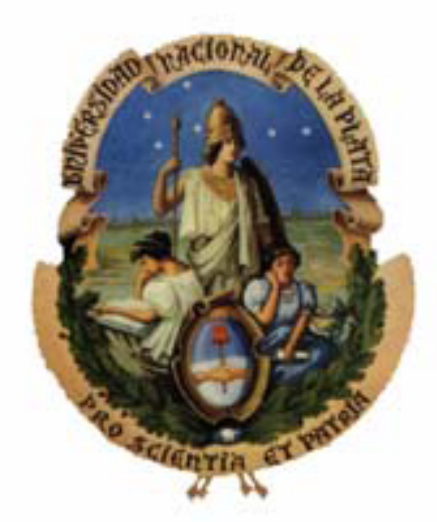

Tesis Doctoral

Universidad Nacional de La Plata Facultad de Ciencias Exactas Departamento de Ciencias Biológicas -2013-

Tesista: Lic. Laura V. Cabaleiro Director: Dr. Horacio Garda Co-Director: Dra. Marina Gonzalez Asesora Científica: Dra. María del R. Gonzalez-Baró 


\section{Agradecimientos}

Al Instituto de Investigaciones Bioquímicas de La Plata (INIBIOLP), al Consejo Nacional de Investigaciones Científicas (CONICET) y a la Universidad Nacional de La Plata (UNLP), que hicieron posible la realización de este trabajo de tesis doctoral.

A mi hermana, mi mamá y mi tía por apoyarme siempre en todos mis proyectos, sin importar los resultados son y serán un ejemplo para mi vida. A pesar de los momentos difíciles, siempre permanecemos unidas.

A mis amigos Mari y Tomy, gracias por aguantarme en todo y ser incondicionales, a Lean porque siempre hay una salida para todo y si la vida te da la espalda tócale el hombro, gracias por tanto cariño y apoyo!!!.

A Solimanosky por tantos años compartidos de mate, café, estudio, charlas, locura, diversión, cansancio y esfuerzo entre otras emociones. Muchos años de Lic. y otros más de Doc., la verdad que todo se hizo más fácil con tu compañía gracias por despertar mi creatividad.

A Anita porque nos enseñamos mutuamente a seguir adelante y no bajar los brazos bajo ninguna circunstancia, a José por ser un guerrero de la vida, a Jorge porque siempre estas y estuviste. A vero porque nos motivamos juntas a terminar con el doctorado.

A mis amigos del lab., Angelita por ser tan expeditiva y darme los mejores consejos en momentos difíciles, a Yani y Viky por tantos lindos momentos compañeras de pelota-paleta, paddle, salidas after-lab., a Aldi por tantas charlas y tardes en Madryn. A Tati por los buenos consejos, a Anita porque no sólo me enseñaste sobre investigación sino de la vida, a Laurita por tantos buenos momentos de té y apoA-I, gracias a todos por el apoyo y contención.

Al $4^{\text {to }}$ piso gracias por hospedarme como mi segundo lugar, a Mony por compartir tantos momentos de alegría, dispersión y trabajo, a Roxana y 
Margarita por tantas charlas y aguantarme a lo largo de todos estos años. A Boris, Nela y Sandra, gracias por los mates y los buenos momentos compartidos.

A los "Betinos" y "Anis" gracias por la buena onda: Marina, Flor, Jorge, Lu, Valeria, Eduardo, Juan Pablo y Lucía.

A Sole, Gaby, Nahuel, Ale y Omar, por ayudarme con muchas técnicas de biología molecular y por los diferentes préstamos: mate, café, azúcar...IPTG etc.

A Eli por estar siempre para cualquier consulta. A Marina y a Juan por enseñarme las diferentes técnicas en cultivo celular y rHDL a lo largo de estos años.

A Horacio Garda por compartir un poco de su capacidad intelectual y calidad de persona con nosotros.

$Y$ a todos aquellos que hicieron muy llevadero y ameno los días de lab. y cátedra: Piky, Eva, Cris, Gra, Nathali, Marisa, Sabri, Ani, Mabel, las chicas de radioisótopos (Laura, Vane, Sabi y Romi) y los Goya (Ignacio, Paula y Silvia).

Si hoy estoy terminando esta etapa, es gracias a ustedes que estuvieron en esos momentos claves, donde uno tiene ganas de dejar todo atrás. Gracias a todos!!!. 
ÍNDICE Y ABREVIATURAS 


\section{ÍNDICE Y ABREVIATURAS}

\section{CAPITULO 1. INTRODUCCIÓN GENERAL}

1.1 COLESTEROL

1.1.1 Vías de absorción del colesterol exógeno …............................................................. 1

1.1.1.1 Vía no selectiva: receptor LDL …..................................................................... 1

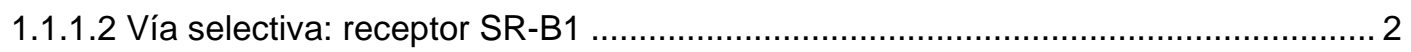

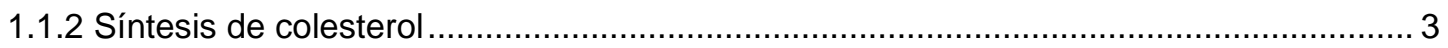

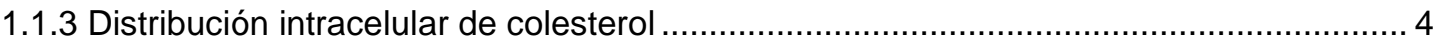

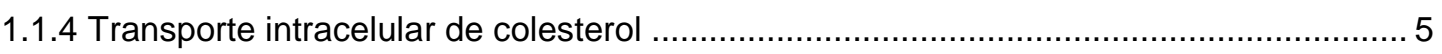

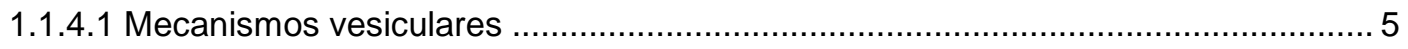

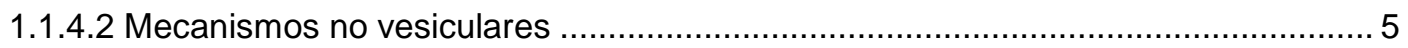

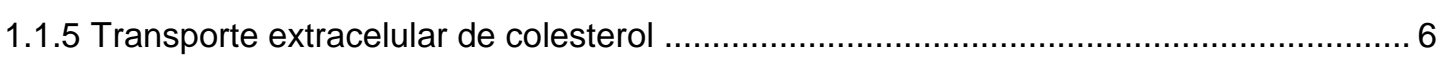

1.1.5.1 Lipoproteínas plasmáticas ........................................................................ 6

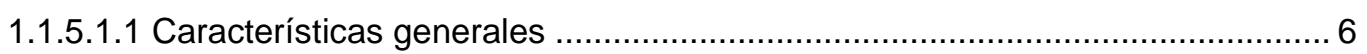

1.1.5.1.2 Metabolismo de lipoproteínas ................................................................ 7

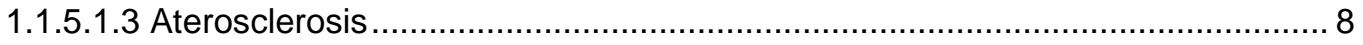

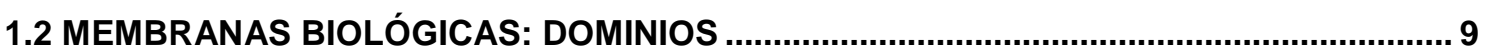

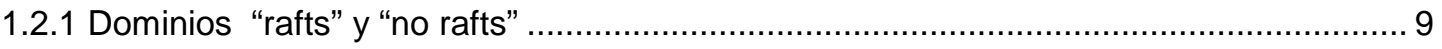

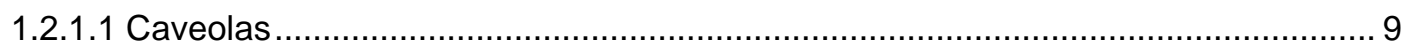

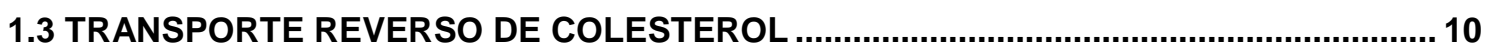

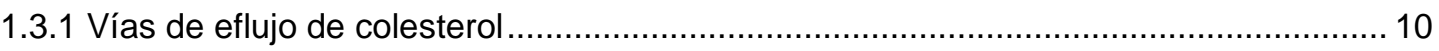

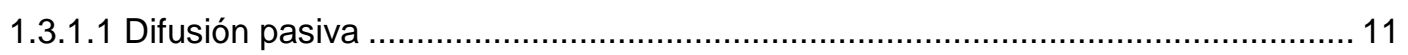

1.3.1.2 Difusión facilitada: vía receptor SR-BI........................................................ 11

1.3.2.3 Transporte activo: transportadores ABCA1 y ABCG1 .......................................... 12

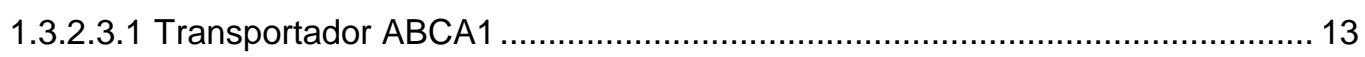

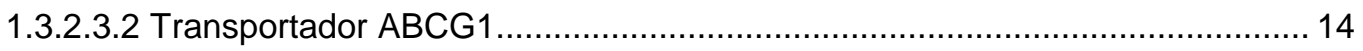

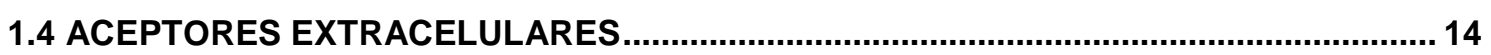

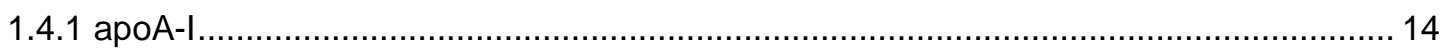

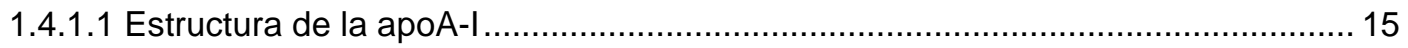

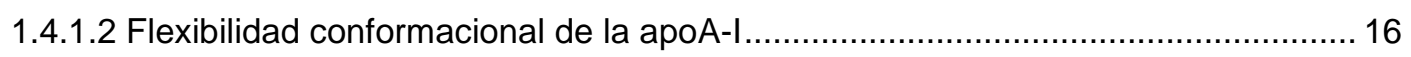

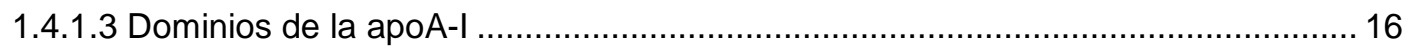

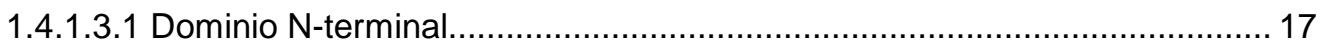

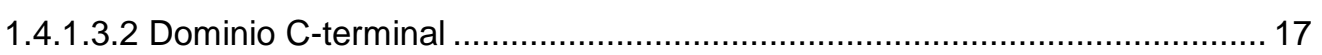

1.4.1.3.3 Dominio Central ............................................................................... 17

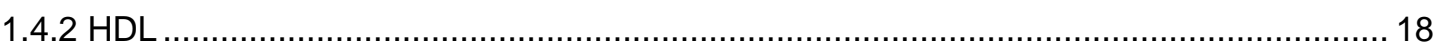

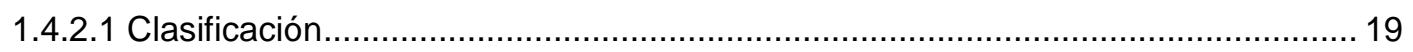

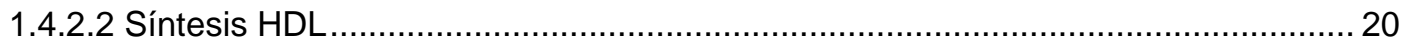

CAPÍTULO 2. HIPÓTESIS Y OBJETIVOS …….......................................................... 22 


\section{CAPÍTULO 3. MATERIALES Y MÉTODOS}

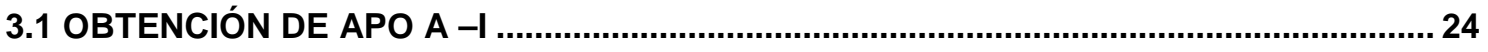

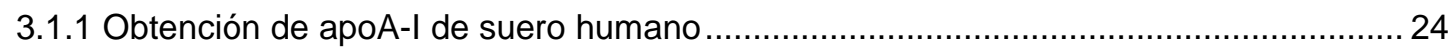

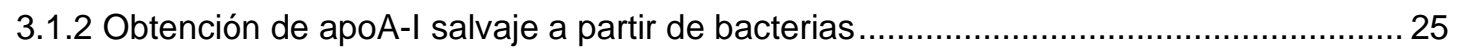

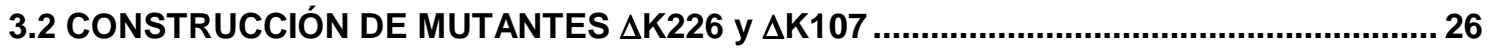

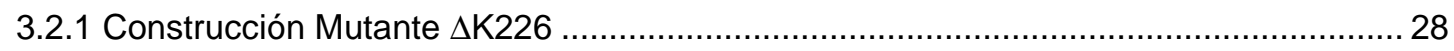

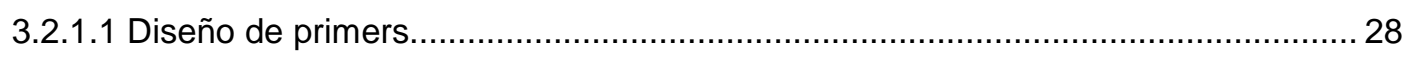

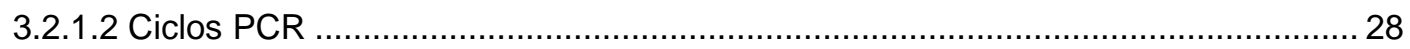

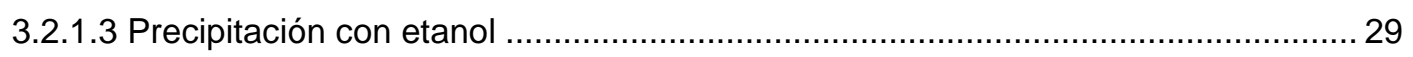

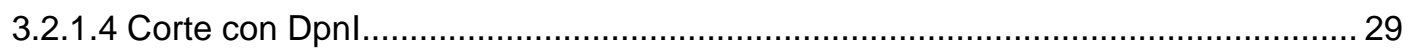

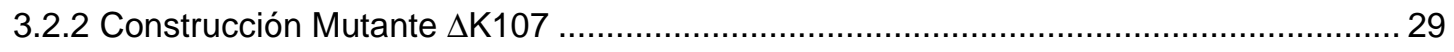

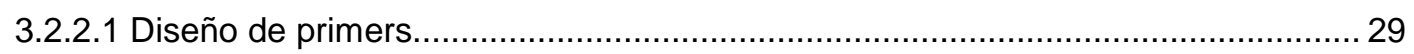

3.3 PROTOCOLOS GENERALES DE TRABAJO CON BACTERIAS..................................... 30

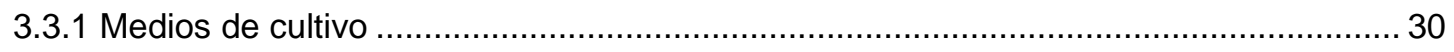

3.3.2 Preparación de bacterias competentes (método de Hanahan) ..................................... 30

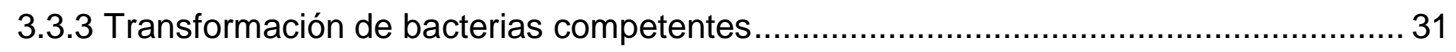

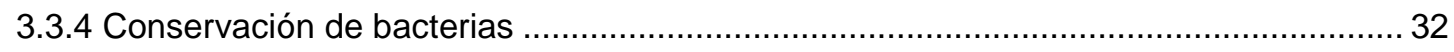

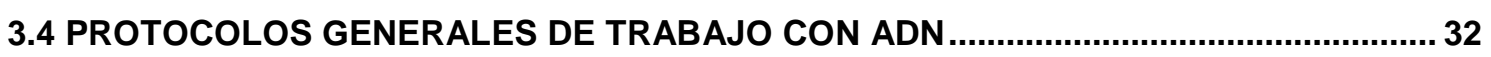

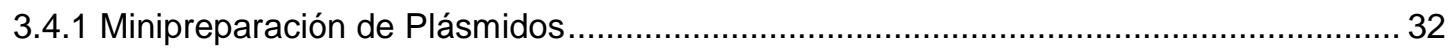

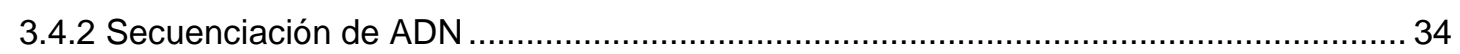

3.4.3 Expresión de proteínas recombinantes ................................................................ 34

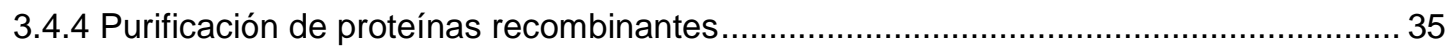

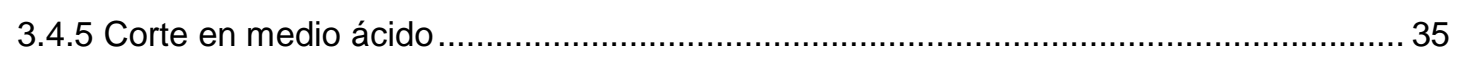

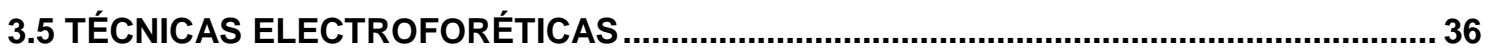

3.5.1 Electroforesis en gel de Poliacrilamida (PAGE) ….................................................... 36

3.5.1.1 Electroforesis PAGE en condiciones nativas ..................................................... 36

3.5.1.2 Electroforesis PAGE en condiciones desnaturalizantes con SDS ......................... 37

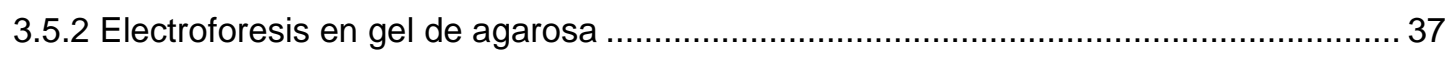

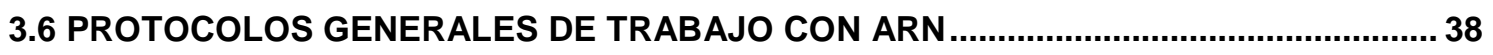

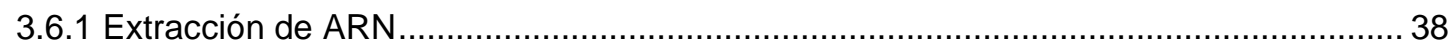

3.6.1.1 Homogenización y precipitación del ARN ....................................................... 38

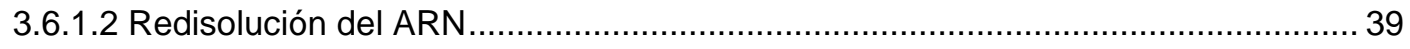

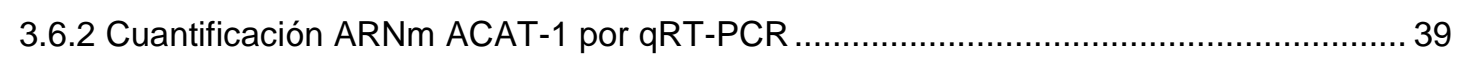

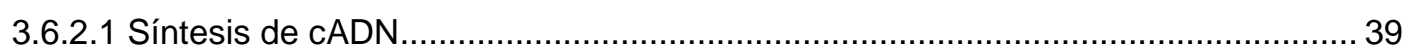

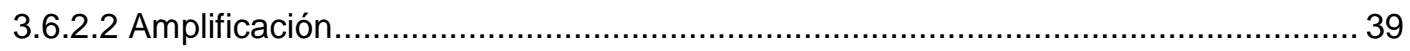

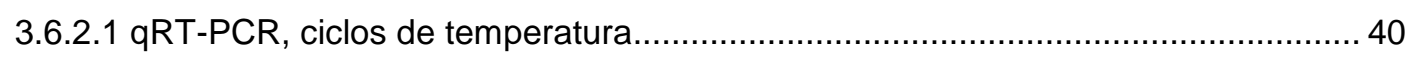

3.7 PROTOCOLOS GENERALES DE TRABAJO CON PROTEÍNAS..................................... 40

3.7.1 Determinación de la concentración proteica................................................................ 40

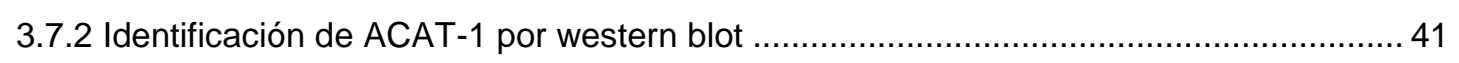

3.7.2.1 Separación y Transferencia de proteínas ........................................................ 41 


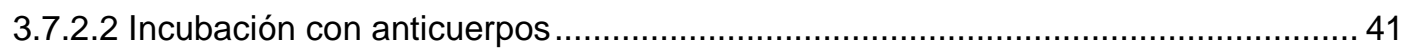

3.8 PROTOCOLOS GENERALES DE TRABAJO CON CÉLULAS.......................................41

3.8.1 Mantenimiento de células en cultivo …................................................................. 42

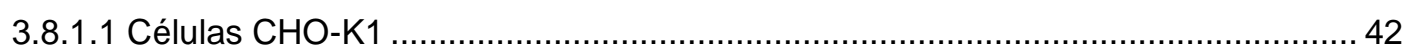

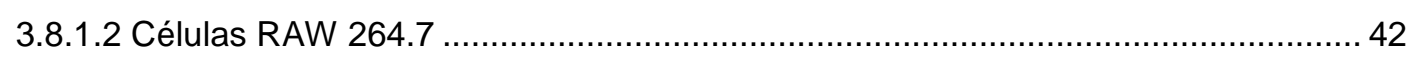

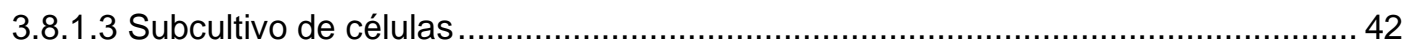

3.8.1.4 Criopreservación de células en nitrógeno líquido ............................................... 43

3.8.1.5 Detección de contaminantes: Micoplasmas ..................................................... 43

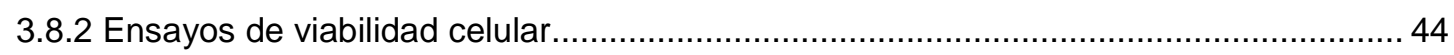

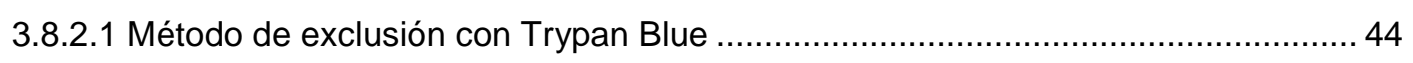

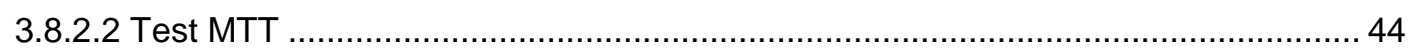

3.8.2.2.1 Efecto citotóxico del colesterol ................................................................... 44

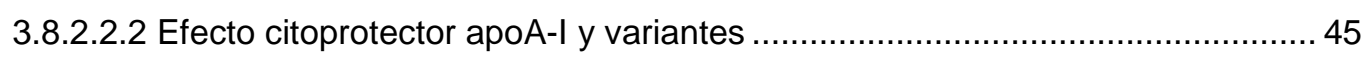

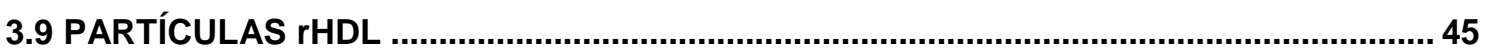

3.9.1 Reconstitución de partículas discoidales: rHDL ........................................................ 45

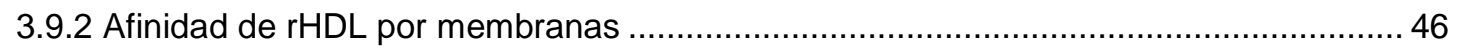

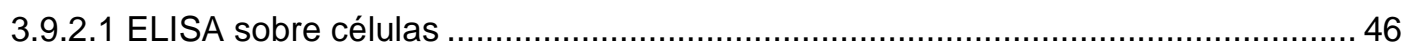

3.10 ENSAYOS DE REMOCIÓN DE LÍPIDOS ................................................................... 47

3.10.1 Ensayo de Remoción de Colesterol ................................................................. 47

3.10.2 Ensayo de Remoción de Fosfolípidos ................................................................. 48

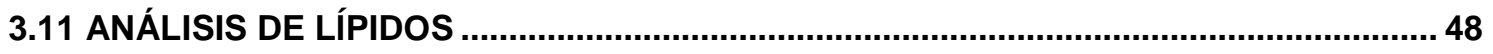

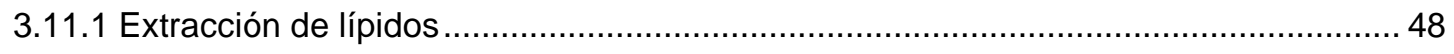

3.11.2 Cromatografía en capa fina (TLC) ………................................................... 49

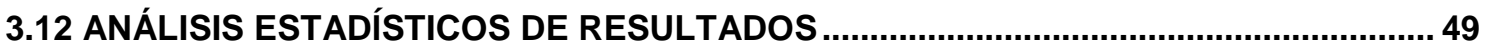

CAPÍTULO 4. COMPORTAMIENTO DE LAS dHDL DE DIFERENTE TAMAÑO Y COMPOSICIÓN EN EL EFLUJO LIPÍDICO CELULAR

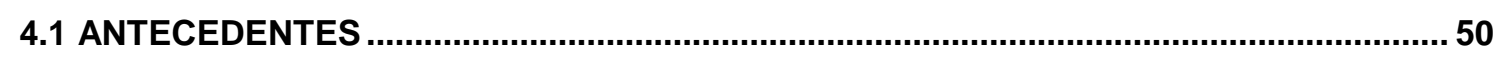

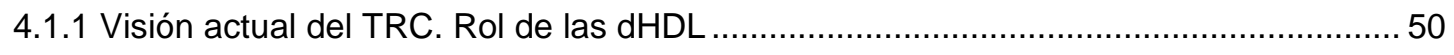

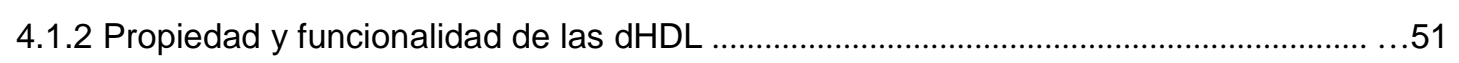

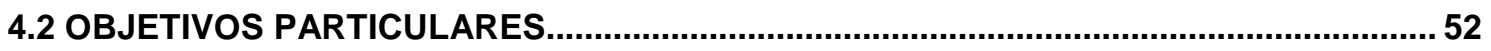

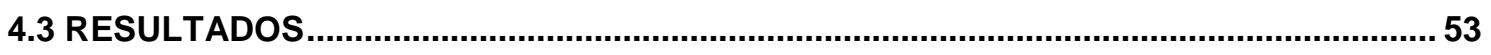

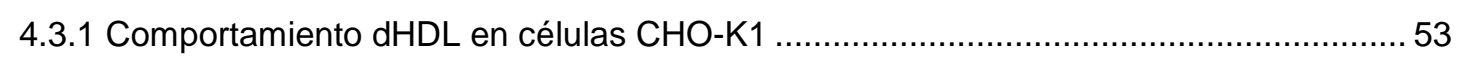

4.3.1.1 Capacidad de unión a la membrana celular ........................................................ 53

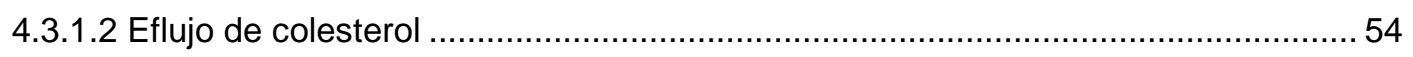

4.3.1.3 Distribución de radioactividad entre colesterol libre y esterificado......................... 56

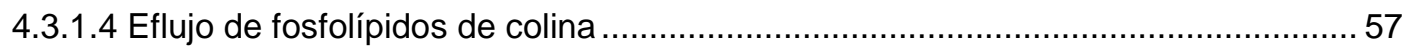

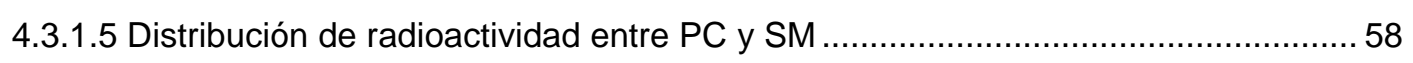

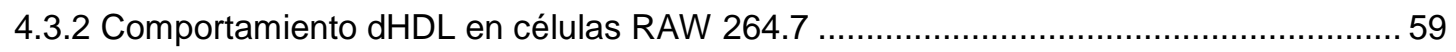




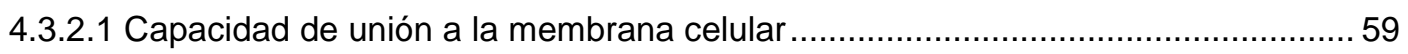

4.3.2.1.1 Determinaciones a $37^{\circ} \mathrm{C}$ con $\mathrm{H}-\mathrm{Col}$ y AR .................................................... 59

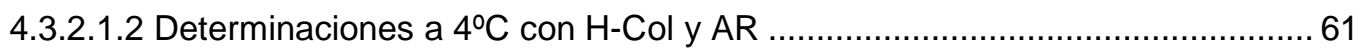

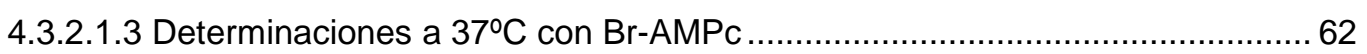

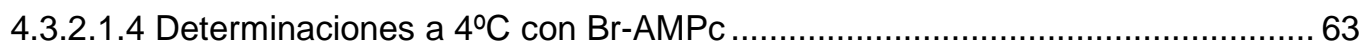

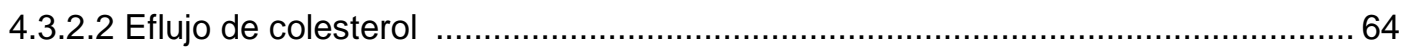

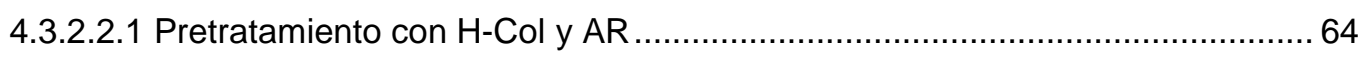

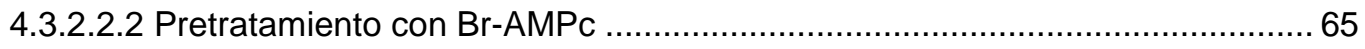

4.3.2.3 Distribución de radioactividad entre colesterol libre y esterificado...........................66

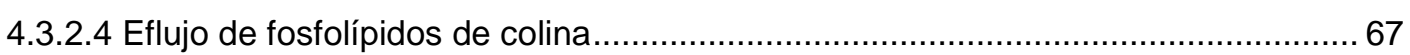

4.3.2.5 Distribución de radioactividad entre PC y SM ...................................................... 68

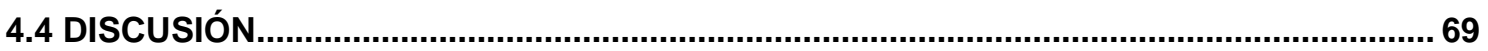

\section{CAPÍTULO 5. VARIANTES APO A-I: $\triangle K 107$ Y $\triangle$ K226 IMPLICANCIAS EN LA REMOCIÓN DE LÍPIDOS}

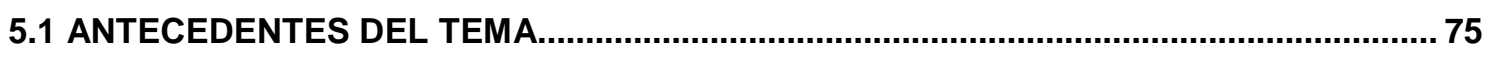

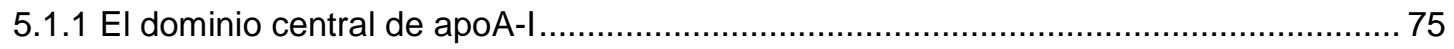

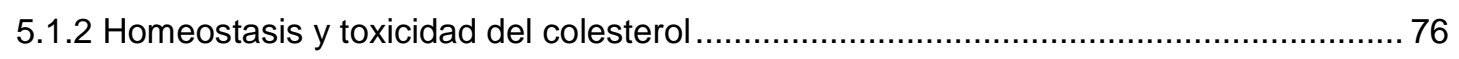

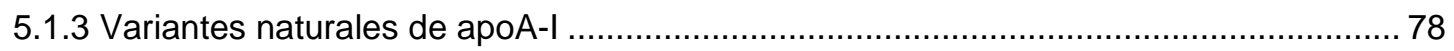

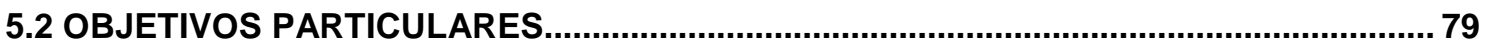

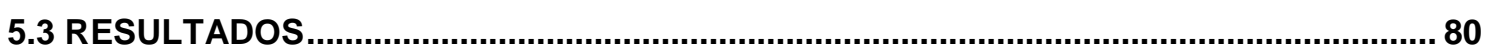

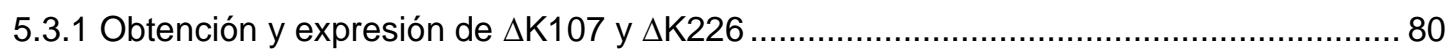

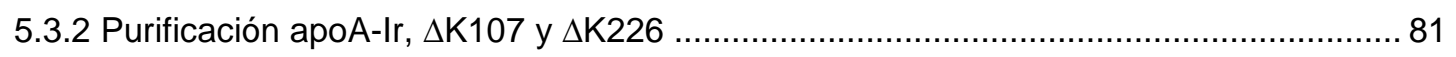

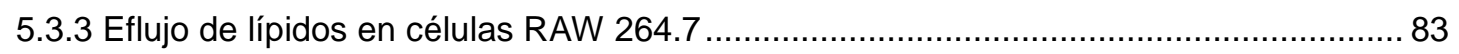

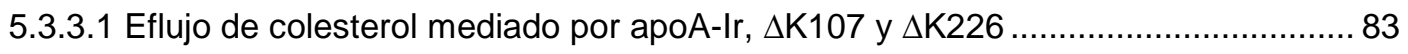

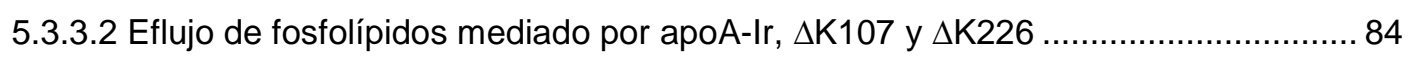

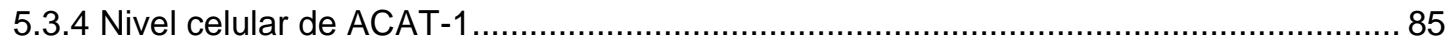

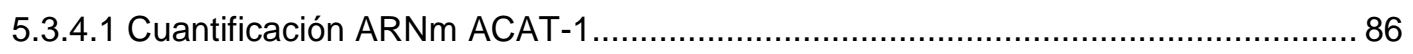

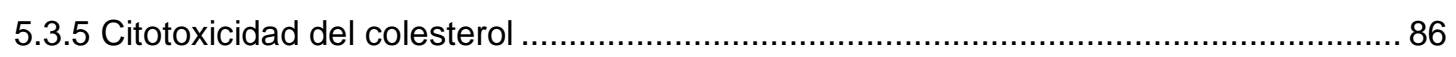

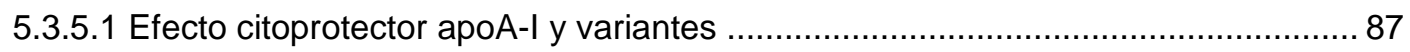

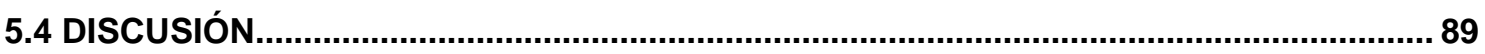

\section{CAPÍTULO 6. CONCLUSIONES}

6.1 Comportamiento de las dHDL de diferente tamaño y composición ..................................93

6.2 Variantes de apoA-I: $\Delta \mathrm{K} 107$ y $\Delta \mathrm{K} 226$. Implicancias en la remoción ............................. 94 


\section{ABREVIATURAS}

ABC: ATP binding cassette

ABCA1: transportador ATP biding cassette A1

ABCG1: transportador ATP bindig cassette G1

ACAT: acil- CoA: colesterol aciltransferasa

AR: 9-cis- ácido retinoico

apoA-I: apolipoproteínaA-I

apoA-Ir: apolipoproteínaA-I recombinante

apoA-Is: apolipoproteínaA-Isérica

Br-AMPc: 8-bromoadenosina-3,5-monofosfato cíclico

BME: $\beta$-mercapto etanol

BSA: albúmina de suero bovina

CE: ésteres de colesterol

$\mathrm{CEH}$ : colesterol éster hidrolasa

CRE: centro de reciclado endosomal

col.: colesterol

CVD: enfermedad cardiovascular

DEPC: dietilpirocarbonato

dHDL: partículas HDL discoidales

DMEM: medio esencial mínimo modificado

DMSO: dimetil sulfóxido

EDTA: ácido etilendiaminotetracético

EL: lipasa endotelial

FC: colesterol libre

FE: fosfatidiletanolamina

FPLC: cromatografía líquida de baja presión

FS: fosfatidilserina

H-Col: 22-R-Hidroxicolesterol

HDL: lipoproteína de alta densidad

HL: lipasa hepática 
HMG-CoA reductasa: $\beta$-hydroxi- $\beta$-metilglutaril CoA reductasa

HSL: lipasa sensible a hormona

IDL: lipoproteína de densidad intermedia

IPTG: isopropil- $\beta$-D-1-tiogalactopiranósido

kDa: kilodaltons

LB: medio Luria Bertani

LD: lipid droplets

LDL: lipoproteína de baja densidad

LCAT: lecitina-colesterol acil transferasa

LPL: lipoprotein lipasa

LXL: receptor $\mathrm{X}$ del hígado

NPC1: Niemann Pick C1

NPC2: Niemann Pick C2

PAGE: electroforesis en gel de poliacrilamida

PC: fosfatidilcolina

PKA: proteína quinasa $\mathrm{A}$

PKC: proteína quinasa C

PL: fosfolípidos

POPC: 1-palmitoil-2-oleoilfosfatidilcolina

rHDL: partículas HDL reconstituídas

RE: retículo endoplásmico

RXR: receptor del ácido retinóico

SDS: dodecilsulfato de sodio

SFB: suero fetal bovino

SM: esfingomielina

SR-BI: receptor scavenger clase B tipo I

TG: triglicéridos

TLC: cromatografía en capa fina

TRC: transporte reverso del colesterol

VLDL: lipoproteína de muy baja densidad 


\section{CAPÍTULO 1. INTRODUCCIÓN GENERAL}




\section{CAPÍTULO 1. INTRODUCCIÓN GENERAL}

\subsection{COLESTEROL}

En mamíferos el colesterol es un componente importante de las membranas celulares. Constituye conjuntamente con todos los elementos de la membrana, la barrera semipermeable de la célula. Esta constituido por un anillo esteroideo rígido y planar, con una cola hidrofóbica, en uno de sus extremos y un grupo funcional 3- B-hidroxilo en el otro. En cuanto a sus funciones regula la fluidez de la membrana, tal que torna más fluida la fase gel y más rígida la fase fluida. Modula el comportamiento de las proteínas de membrana e interviene en procesos de señalización celular. Además es el precursor biosintético de hormonas esteroideas, vitamina $D$ y ácidos biliares. Se encuentran dos fuentes del colesterol celular, el exógeno proveniente de las lipoproteínas y el endógeno sintetizado de novo a nivel del retículo endoplasmático (RE), que está finamente regulado a través de un sistema sensor de esteroles INSIG/SCAP/SREBP.

\subsubsection{Vías de absorción del colesterol exógeno}

Se encuentran dos vías mediante las cuales las células pueden absorber el colesterol, una vía no selectiva, por medio del receptor LDL (LDLR) y otra selectiva a través del receptor SR-BI (Rone, Fan y Papadopoulos, 2009).

\subsubsection{Vía no selectiva: receptor LDL}

Esta vía se inicia primariamente cuando las lipoproteínas de baja densidad (LDL) contactan con su receptor en la superficie celular, son endocitadas en vesículas revestidas de clatrina y se dirigen a la vía endosomal/isosomal (Ungewickell y col., 2007). A nivel de endosomas y lisosomas encontramos proteínas transferidoras de colesterol como la Niemann Pick C1 (NPC1), Niemann Pick C2 (NPC2) y MLN64, que permiten la salida del colesterol. Por otro lado la disminución del $\mathrm{pH}$, desde la membrana plasmática hacia los 
endosomas, posibilita la fusión de endosomas con lisosomas y la disolución de las lipoproteínas (Mukherjee y Maxfield, 2004).

\subsubsection{Vía selectiva: receptor SR-B1}

El receptor SR-BI, se encarga de la captación selectiva de colesterol y ésteres de colesterol (CE) de partículas HDL principalmente. El flujo de colesterol vía receptor SR-BI, puede ser bidireccional dependiendo del gradiente de concentración. La expresión de este receptor difiere en los distintos tipos celulares y depende del estado metabólico de la célula. Se expresa en altas concentraciones en hepatocitos y células esteroidogénicas (glándula adrenal y gónadas), que requieren de colesterol y ésteres de colesterol para la síntesis de ácidos biliares y esteroides respectivamente. Pero también se encuentra en menor concentración, en células epiteliales, macrófagos y enterocitos (Connelly y Williams, 2003).

A diferencia del receptor LDL, el SR-BI utiliza un mecanismo distinto a la endocitosis para la absorción de lípidos (Connelly y Williams, 2003). Se han postulado varios modelos de absorción, según Gu y col. (1998), el receptor SRBI provoca la hemifusión de la monocapa externa de la membrana plasmática, con la monocapa de fosfolípidos de las HDL. Por el contrario Rodrigueza y col. (1999), postulan que el SR-BI forma un canal no acuoso entre las HDL y la membrana plasmática, mediante el cual los lípidos no polares (colesterol, ésteres de colesterol y triglicéridos), pueden difundir a favor del gradiente de concentración. Este modelo es el más aceptado, debido a que las HDL, transfieren diferentes lípidos, en base a su polaridad, vía el receptor SR-BI. Los lípidos de mayor velocidad de transferencia, son moléculas no polares, como colesterol, ésteres de colesterol y triglicéridos. Los de menor velocidad de transferencia son moléculas polares como fosfolípidos (Thuahnai y col., 2001; Connelly y Williams, 2003). El colesterol absorbido vía SR-BI puede ser almacenado en pooles activos de la membrana plasmática y los ésteres de colesterol deben ser hidrolizados para su posterior utilización. En células esteroidogénicas, los ésteres de colesterol son hidrolizados rápidamente cerca de la membrana plasmática, por una colesterol éster hidrolasa (CEH), la lipasa sensible a hormona (HSL) (Kraemer y col., 2002), luego el colesterol es 
rápidamente dirigido hacia la membrana externa mitocondrial, para la síntesis de esteroides.

\subsubsection{Síntesis de colesterol}

La síntesis de colesterol en mamíferos, puede ser llevada a cabo en diferentes tipos celulares. Es un proceso biosintético complejo, que comienza con acetil CoA y requiere de al menos 27 enzimas, para formar cuatro intermediarios claves, mevalonato, farnesil fosfato, escualeno, lanosterol y finalmente colesterol (Urbani y Simoni, 1990). La enzima 3-hidroxi-3-metilglutarilCoenzima A reductasa (HMG-CoA) (fig.1-1), cataliza la reacción limitante de la biosíntesis de colesterol. El colesterol LDL (Brown y Goldstein, 1980) y ciertas drogas, como las estatinas (Clunn y col., 2010), disminuyen la actividad de la HMG-CoA reductasa, inhibiendo la síntesis de colesterol.

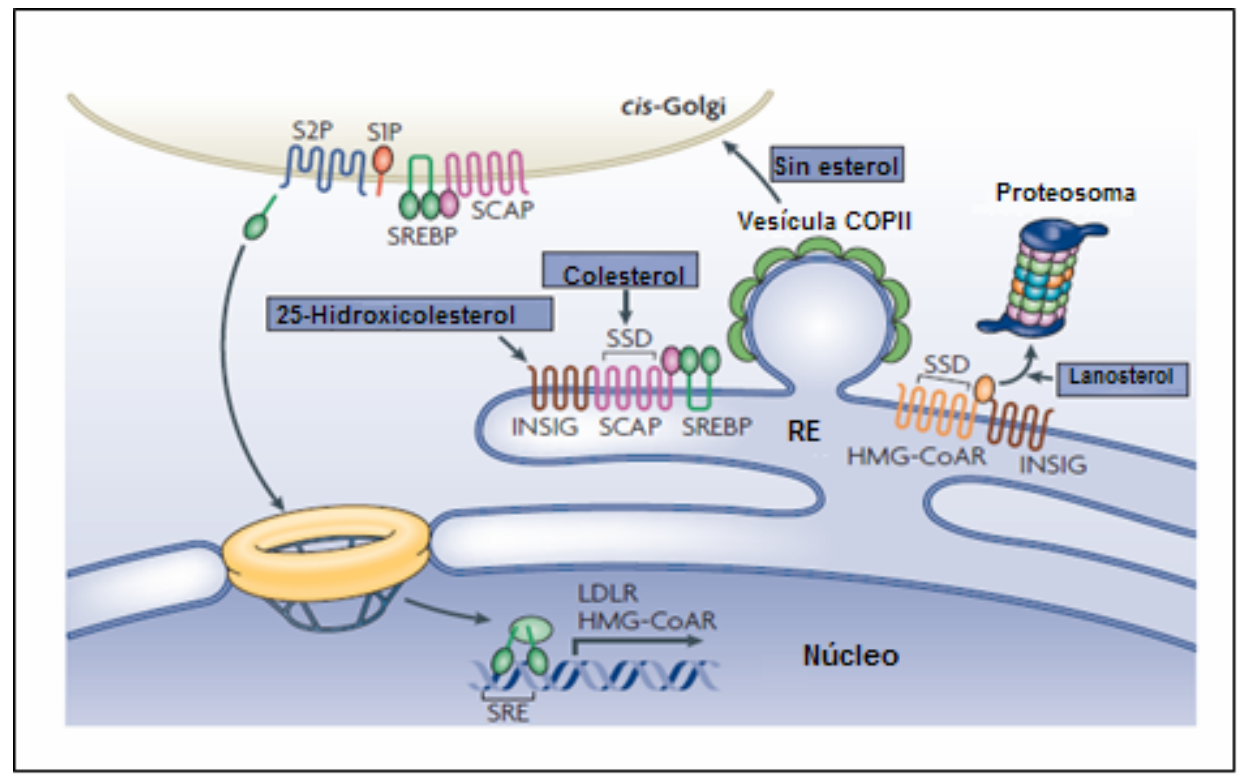

Figura 1-1. Regulación coordinada de la síntesis y captación de colesterol (Ikoen, 2008 con modificaciones). A nivel del RE se encuentra el sistema sensor de esteroles INSIG/SCAP/SREBP que en su estado inactivo, esta anclado al RE, el SREBP (sterol regulatory element binding protein) permanece asociado a SCAP (SREBP cleavage-activating protein). Cuando los niveles intracelulares de colesterol principalmente aumentan, este y otros esteroles se unen a SCAP e INSIG impidiendo que el complejo se disocie. Cuando disminuye el nivel de colesterol intracelular, el complejo se disocia del RE y SCAP/SREBP migran al Golgi. Allí el SREBP es clivado y el extremo amino terminal se dirige al núcleo, donde funciona principalmente como factor de transcripción del gen de la HMG-CoA reductasa como también del receptor de LDL (Hua y col. 1993). 


\subsubsection{Distribución intracelular de colesterol}

El mayor reservorio de colesterol celular, se encuentra en la membrana plasmática. Inicialmente se localiza en las caveolas (Liscum y Munn, 1999) y luego se distribuye a diferentes dominios de membrana o bien a aceptores extracelulares (Fielding y Fielding, 1996; Uittenbogaard y Smart, 1998). Altas concentraciones se observan a nivel del trans- Golgi y compartimiento de reciclado endosomal (CRE) (Liscum y Munn, 1999; Mukherjee y col., 1998; Hao y col., 2002). El CRE forma parte del sistema endocítico de membrana, conjuntamente con endosomas tempranos (o de reparto) y tardíos (o cuerpos multilamelares). Consiste en una extensa red de túbulos, que distribuye moléculas a distintos compartimentos, pero su función principal es reciclar componentes de membrana y distribuirlos nuevamente a la superficie celular (Saraste y Goud, 2007). El colesterol del CRE proviene tanto de vías endógenas como exógenas (Mukherjee y col., 1998).

Ha sido propuesto que a nivel del Golgi, se forman los rafts ricos en colesterol, que son transportados desde el trans-Golgi hacia la periferia (Simons y Ikonen, 1997; Ikonen, 2001).

A pesar de que, la síntesis de novo de colesterol se produce en el RE, la concentración de colesterol es baja en este compartimento subcelular, entre el 0,5 al $1 \%$ del colesterol celular total (Lange y col., 1999). Esto puede ser debido, a la fina regulación de la síntesis de colesterol y al sensor de esteroles, INSIGHT/SCAP/SREBP, a nivel de la membrana del RE.

Con respecto a las mitocondrias, la concentración de colesterol es baja. En células esteroidogénicas, las mitocondrias se encargan de sintetizar esteroides, en el momento de síntesis, el colesterol es traslocado hacia la mitocondria (Rone, Fan y Papadopoulos, 2009).

El colesterol intracelular en exceso es tóxico (Tabas, 1997; Warner y col., 1995), pero es esterificado por la enzima acil- CoA: colesterol aciltransferasa (ACAT) del RE y almacenado en forma no tóxica en lipids droplets (LD) (Chang y col., 1997). 
Dado que diversos mecanismos operan al mismo tiempo en la absorción, síntesis y distribución de colesterol, la combinación de estos mecanismos hace muy difícil el estudio y comprensión del metabolismo intracelular de colesterol. Actualmente se han realizado muchos avances a nivel de estos mecanismos, sin embargo todavía no se conocen con exactitud.

\subsubsection{Transporte intracelular de colesterol}

El colesterol se puede transportar intracelularmente por mecanismos vesiculares o nó vesicular (Maxfield y col., 2005; Hao y col., 2002).

\subsubsection{Mecanismos vesiculares}

Los mecanismos vesiculares se refieren al transporte de componentes de membrana entre compartimentos subcelulares a lo largo del citoesqueleto, con gasto de ATP (Mobius y col., 2003; Ikonen, 2008).

\subsubsection{Mecanismos no vesiculares}

El mecanismo de tráfico no vesicular, presumiblemente es llevado a cabo por proteínas transferidoras de lípidos o por contacto directo entre membranas. Este mecanismo juega un rol importante en el transporte de colesterol (Prinz, 2007). Encontramos varias familias de proteínas trasferidoras de lípidos: Niemann Pick C (NPC), caveolinas, proteína de unión a oxisterol (OSBP), proteínas relacionadas a OSBP (ORP), proteína transferidora de esteroles (SCP-2), proteínas de la regulación aguda esteroidogénica (START).

El colesterol sintetizado de novo deja rápidamente el $\mathrm{RE}$, mediante mecanismos no vesiculares (Ikoen, 2008), en complejos con chaperonas y caveolina (Uittenbogaard y Smart, 1998) y es llevado directamente a la membrana plasmática donde, estará disponible a aceptores extracelulares (Lusa, 2003); o bien mediante mecanismos vesiculares, atraviesa el Golgi donde se distribuye en los rafts (Maxfield y Wustner, 2002). Estos dos mecanismos podrían ocurrir en paralelo en la célula. El transporte de colesterol 
intracelular, tanto vesicular como no vesicular, es un área de activa investigación, ya que sus mecanismos no se conocen completamente.

\subsubsection{Transporte extracelular de colesterol}

A nivel extracelular el colesterol puede ser transportado en lipoproteínas plasmáticas, desde hepatocitos y enterocitos, a partir de la síntesis endógena de lipoproteínas, o bien desde células periféricas hacia el hígado, para su catabolismo o síntesis de ácidos biliares.

\subsubsection{Lipoproteínas plasmáticas}

Las lipoproteínas son complejos supramoleculares, constituidos por lípidos y apolipoproteínas. Se pueden clasificar según su densidad en: quilomicrones (QM), lipoproteínas de muy baja densidad (VLDL), lipoproteínas de densidad intermedia (IDL), lipoproteínas de baja densidad (LDL), lipoproteína (a) Lp(a) y lipoproteínas de alta densidad (HDL).

\subsection{Características generales}

Los QM se sintetizan en los enterocitos, con el fin de transportar los lípidos dietarios hacia el hígado. Están constituidos por un 90\% de triglicéridos (TG). Son las lipoproteínas menos densas y más grandes. Se encuentran dos tipos, QM nacientes $\left(\mathrm{QM}_{\mathrm{n}}\right)$ y $\mathrm{QM}$ remanentes $\left(\mathrm{QM}_{\mathrm{r}}\right)$. Los quilomicrones nacientes $\left(Q M_{n}\right)$ recién sintetizados tiene apoB-48, apoA-I, A-II, y A-IV. En el proceso de maduración en la circulación plasmática pierden las apoA y reciben apoC-I, C-II y $E$ de las HDL.

Las VLDL se sintetizan a nivel del hepatocito y cumplen la función de transportar los TG de síntesis endógena, además de redistribuir ácidos grasos y colesterol a todos los tejidos. Al igual que los $\mathrm{QM}_{\mathrm{n}}$ son lipoproteínas grandes y poco densas. Las apolipoproteínas principales son apo B-100, C-II, C-III y E.

Las IDL son el producto del catabolismo parcial de las VLDL. Son de menor tamaño y mayor densidad que sus progenitoras. En relación a su contenido 
lipídico, presentan aproximadamente la misma cantidad de colesterol y TG. Con respecto a las apolipoproteínas, las más importantes son la apoB-100 y apoE. Debido al contenido de colesterol y su tamaño pequeño, tienen un elevado potencial aterogénico.

Las LDL se forman a partir del catabolismo parcial de las IDL. Son más densas y de menor tamaño que las IDL y la apo mayoritaria es la apoB-100. Cumplen la función principal de distribuir colesterol a todos los tejidos y debido al alto contenido de colesterol que transportan y a su tamaño, tienen también un alto potencial aterogénico.

La Lp(a) presenta una estructura similar a la LDL, sólo que esta constituida por otra apolipoproteína la apo(a), unida covalentemente a la apo B-100. Al igual que las IDL y LDL, tiene un alto potencial aterogénico, pero todavía no se conoce muy bien su función.

Las HDL se sintetizan a nivel de los hepatocitos, enterocitos o del catabolismo de otras lipoproteínas. Se pueden encontrar distintas clases de HDL. Son las lipoproteínas más densas y de menor tamaño. La apoA-I es el componente apolipoproteíco mayoritario, pero también presentan apoA-II, C y E. Una descripción más detallada sobre estructura, clasificación y metabolismo de las HDL y apoA-I, se realizará seguidamente en la sección 1.4 Aceptores extracelulares.

\subsection{Metabolismo de lipoproteínas}

Los $\mathrm{QM}_{\mathrm{n}}$ interaccionan a nivel de los tejidos, con la lipoprotein lipasa (LPL) que se encuentra en la superficie del endotelio vascular. La LPL hidroliza TG, liberando ácidos grasos y glicerol. Los ácidos grasos ingresan a los tejidos, como el muscular y adiposo, y el glicerol se dirige al hígado, donde ingresará a la vía gluconeogénica o glucolítica, dependiendo de las condiciones metabólicas de la célula. Así los $\mathrm{QM}_{\mathrm{n}}$ pierden $\mathrm{TG}$ y se convierten en $\mathrm{QM}_{\mathrm{r}}$, que serán tomados por el hígado y metabolizados. Las VLDL, sintetizadas en el 
hígado, presentan principalmente TG que son hidrolizados por LPL. A medida que disminuye la concentración de TG, la VLDL se convierte en IDL. La IDL por acción de la lipasa hepática (HL), que hidroliza TG, se convierte en LDL, la cual es tomada por las células como fuente de colesterol exógeno, principalmente vía receptor LDL.

A nivel del plasma las lipoproteínas sufren remodelaciones continuamente, debido en parte, a la acción de enzimas que transfieren lípidos entre ellas, como las proteínas transferidoras de ésteres de colesterol (CETP) y de fosfolípidos (PLTP).

El colesterol es removido de las células periféricas, por medio de otro tipo de lipoproteína, las HDL que participan activamente en el transporte reverso de colesterol (TRC), proceso mediante el cual las HDL llevan el colesterol hacia el hígado, para que sea metabolizado a ácidos biliares o excretado por las heces.

\subsubsection{Aterosclerosis}

La aterosclerosis es una enfermedad cardiovascular crónica, degenerativa y multifactorial. Es la primer causa de mortalidad en el mundo occidental (Singh y col., 2002). Se caracteriza por la acumulación de lípidos intra y extracelularmente, la infiltración de monocitos, proliferación de células musculares lisas y acumulación de elementos del tejido conectivo en la pared arterial y además por la formación de trombos (Singh y col., 2002).

En base a numerosos estudios epidemiológicos se ha establecido una relación inversa entre el colesterol-HDL (c-HDL), el desarrollo de enfermedad cardiovascular y aterogénesis (Barter y col, 2007; Gordon y col., 1977). La relación entre el c-HDL y el riesgo de enfermedad cardiovascular, se ha atribuido principalmente al rol protagónico que cumplen las HDL en el TRC. Además las HDL presentan otras propiedades relacionados con la acción antiaterogénica, como antiinflamatorias, antitrombóticas y antioxidantes (Rye y col, 2009). 


\subsection{MEMBRANAS BIOLÓGICAS: DOMINIOS}

A nivel de la membrana se encuentran zonas especializadas, que cumplen diversas funciones y tienen una composición determinada. Estas zonas se denominan dominios. Según su solubilidad en detergentes no iónicos, se puede hablar de dominios "rafts" (insolubles en detergentes) y "no rafts" (solubles en detergentes). La existencia de estos dominios ha sido controvertida, debido a la dificultad de visualizarlos in vivo ya que son muy dinámicos (Edidin, 1993).

\subsubsection{Dominios "rafts" y "no rafts"}

Los lipids rafts son ensamblajes dinámicos de colesterol y esfingolípidos, que pueden incluir o excluir proteínas, formando microambientes específicos en la superficie celular. Estos dominios son importantes en la transducción de señales (Fielding y Fielding, 2003). Forman plataformas para receptores individuales, que se activan por la interacción del ligando con el receptor (Simons y Toomre, 2000).

\subsubsection{Caveolas}

Las caveolas son lipids rafts especializados, que forman invaginaciones en la membrana plasmática. Están involucrados en la señalización y transporte celular como así también en la homeostasis del colesterol. La organización y función de las caveolas esta controlada por las caveolinas y cavinas. Estas últimas son proteínas adaptadoras, que además controlan la función de las caveolinas (Chidlow y Sessa, 2010). Las caveolas se encuentran en distintos tipos celulares en cantidad variable. Son comunes en células epiteliales, adiposas y fibroblastos. Las caveolinas-1,-2 y -3 forman el esqueleto de la caveola. Estas proteínas están altamente integradas a la función de la caveola, pero también cumplen una función independiente. Se ha postulado que intervienen en el transporte de colesterol sintetizado de novo, vía no vesicular, desde RE hacia la membrana plasmática, en un complejo citosólico formado por chaperonas, proteínas de choque térmico y colesterol (Uittenbogaard y Smart, 1998). 
En cuanto a las caveolas, su funcionamiento es controversial. Según Fielding (2003), el eflujo de colesterol ocurre a nivel de las caveolas, pero Mendez y col. (2001) consideran a los dominios "no rafts" como regiones óptimas para el eflujo de colesterol, dado que los componentes de la membrana se encuentran menos empaquetados, condición necesaria para la microsolubilización de lípidos. Un soporte a esta hipótesis, es el hecho que el transportador ABCA1 se encuentre en dominios "no rafts" (solubles a detergentes), por lo tanto el ABCA1 no estaría asociado a las caveolas ni a la caveolina. Debido a ello se encuentra en discusión el papel que cumplen las caveolas y la caveolina, en el eflujo de colesterol hacia la apoA-I y dHDL de tamaño pequeño, vía transportador ABCA1 (Favari y col., 2009).

\subsection{TRANSPORTE REVERSO DE COLESTEROL (TRC)}

EI TRC, es el mecanismo mediante el cual las HDL remueven el colesterol de células periféricas y lo transportan al hígado para ser metabolizado. El primer paso en el TRC es el eflujo de colesterol hacia aceptores extracelulares, como apoA-I y HDL. A nivel de células periféricas, el eflujo de colesterol hacia la apoA-I y HDL es el único mecanismo de remoción de colesterol, a diferencia de células esteroidogénicas, hepatocitos o enterocitos, donde el colesterol puede ser metabolizado a hormonas esteroideas, lipoproteínas nacientes y ácidos biliares.

\subsubsection{Vías de eflujo de colesterol}

El eflujo de colesterol puede ocurrir al menos por tres vías (fig.1-3) 1) difusión pasiva (Philiphs y col., 1987), 2) difusión facilitada, vía receptor SR-BI (Rothblat y col., 1999) y 3) transporte activo por medio de los transportadores ABCA1 y ABCG1 (Cavelier y col., 2006). La importancia de cada vía depende del aceptor extracelular, del tipo de célula y su estado metabólico (Rothblat y col., 1999). 


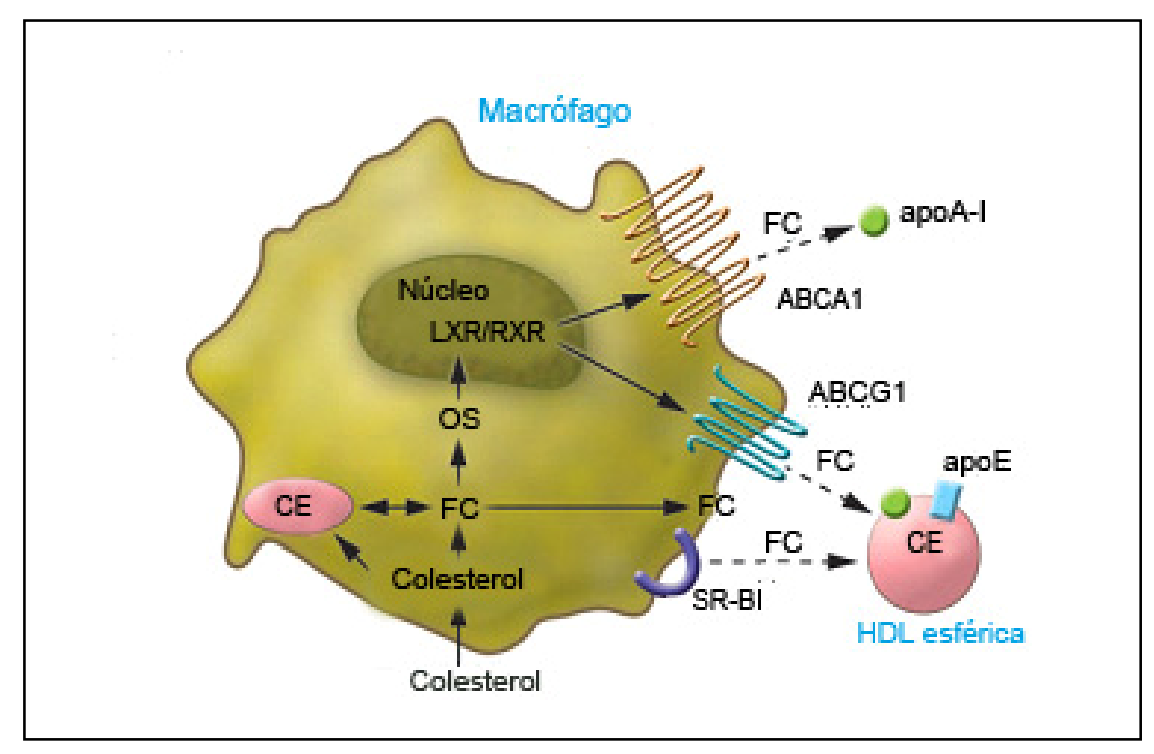

Figura 1-3. Vías de Eflujo de colesterol en macrófagos (Rader, 2006 con modificaciones). El eflujo de FC hacia la apoA-I ocurre vía transportador ABCA1 y hacia las HDL maduras vía transportador ABCG1. El eflujo de colesterol hacia las dHDL puede ocurrir vía transportador $A B C A 1$, en el caso de las dHDL $\leq 78$ Å, o vía el transportador ABCG1 (Favari y col., 2009). Ambos transportadores están regulados por el receptor nuclear $L X R / R X R$, que se activa por oxiesteroles y ácido retinoico. El receptor SR-BI también puede mediar el flujo de FC hacia las dHDL y HDL maduras.

\subsubsection{Difusión pasiva}

Este proceso involucra la desorción de colesterol de la membrana, desde la interfase lípido-agua, y su difusión a favor del gradiente de concentración, a través de la fase acuosa hasta que colisiona y es adsorbido por el aceptor. La difusión acuosa puede verse favorecida, por la reducción del empaquetamiento de la membrana, debido a altas curvaturas, insaturaciones en la cadena acilo de fosfolípidos o una baja relación de esfingomielina/fosfatidilcolina (Yancey y col., 2003). Antiguamente se suponía que el eflujo de colesterol sólo se llevaba a cabo por este mecanismo, ya que no se conocían los transportadores.

\subsubsection{Difusión facilitada: vía receptor SR-BI}

El receptor SR-BI, es un receptor multiligando perteneciente a la Familia CD36. Tiene la capacidad de interactuar con HDL y LDL, y mediar el flujo bidireccional de colesterol y ésteres de colesterol entre la célula y las lipoproteínas. La expresión del receptor SR-BI es diferente en los distintos tipos celulares, y la carga de colesterol como el hidroxicolesterol y ácido retinoico, disminuyen su expresión (Ji y col., 2011; Yu y col., 2004). En células no cargadas con 
colesterol, la mayor parte de eflujo es atribuido a la difusión acuosa y la menor parte al receptor SR-B1 (Adorni y col., 2007). Cuando la célula se carga con colesterol disminuye la expresión del ARNm del SR-BI como así también la cantidad de proteína (Yu y col., 2004) y se incrementa la expresión del ABCA1 y ABCG1 (Chawla y col, 2001).

\subsubsection{Transporte activo: transportadores ABCA1 y ABCG1}

El eflujo de colesterol se puede producir por transporte activo, con gasto de ATP, en contra del gradiente de concentración, mediante los transportadores $A B C A 1$ y $A B C G 1$. Los transportadores $A B C$ son proteínas integrales de membrana multipaso, que transfieren lípidos de la cara interna hacia la externa de la membrana plasmática (Oram y Vaughan, 2006). Están regulados por factores de transcripción heterodiméricos, entre otros, como el receptor $X$ del hígado (LXR) y receptor del ácido retinoico (RXR) (Shiabata y Glass, 2010). Los ligandos de estos receptores son los oxiesteroles y el ácido retinoico, como el 22-R-Hidroxicolesterol ( $\mathrm{H}$-Col) y el 9-cis-ácido retinoico (AR). Estos factores de transcripción inducen la sobreexpresión de los transportadores ABCA1 y ABCG1 (Chawla y col, 2001) y disminuyen la expresión del SR-BI (Lorenzi y col., 2008).

Como se mencionó anteriormente estudios realizados in vitro en células cargadas con colesterol, demostraron que el eflujo de colesterol hacia la apoA-I y dHDL se llevaría a cabo principalmente por medio de los transportadores ABCA1 y ABCG1, ambos transportadores trabajarían coordinadamente. Aproximadamente el ochenta por ciento del eflujo de colesterol es llevado a cabo por el ABCA1 y el veinte por ciento restante, por el ABCG1 (Adorni y col., 2007). Estos resultados se correlacionan con los obtenidos por Wang y col., (2007) en ensayos in vivo en macrófagos murinos cargados con colesterol, dónde el SR-BI no fue eficiente en el eflujo de colesterol. 


\subsection{Transportador ABCA1}

El ABCA1 es una proteína integral de membrana, multipaso, con seis dominios transmembrana, que presenta una región hidrofóbica y otra hidrofílica que da hacia la cara citosólica (Oram y Vaughan, 2006). Transporta a través de la membrana fosfolípidos, colesterol y otros compuestos lipofílicos. EI ABCA1 es principalmente un transportador de fosfolípidos (Oram y Vaughan, 2006). Se localiza a nivel de la membrana celular, como también en membranas intracelulares del retículo endoplasmático y mitocondrias (Dean y col. ,2001).

Los aceptores de colesterol preferidos por el ABCA1, son las apolipoproteínas pobres en lípidos con alto contenido en a-hélices, como la apoA-I, apoA-II y apoE. Recientemente se descubrió que además de las apolipoproteínas, las partículas rHDL $78 \AA$ también interaccionan con el transportador ABCA1 (Favari y col., 2009). A nivel del eflujo de colesterol el ABCA1, induce la formación de una protrusión en la membrana plasmática, gracias a su actividad translocasa de lípidos, que genera una tensión provocando la curvatura de la misma y facilitando de esta manera, la unión de la apoA-I y partículas dHDL de tamaño pequeño (Vedhachalam y col., 2007; Lin y Oram, 2000). La actividad traslocasa de lípidos del ABCA1, incrementa la fluidez de la membrana, desempaquetando la membrana y posibilitando de esta manera la curvatura de la misma y la consiguiente microsolubilización de lípidos (Nandi y col., 2009). Existe cierta controversia con respecto a este mecanismo dado que algunos autores como Fielding y Fielding, (2003) sugieren que el eflujo de colesterol ocurre en dominios "rafts" de la membrana, ricos en esfingolípidos y colesterol, pero el ABCA1 disrrumpe los dominios "rafts" y hace que el colesterol este más accesible, facilitando de esta manera la interacción de la apoA-I y el eflujo. Según Landry y col., (2006), Mendez y col., (2001) y Drobnik y col., (2002), el eflujo de lípidos ocurre a nivel de los microdominios "no rafts" de membrana y este hecho se relaciona con la localización del ABCA1 en dominios solubles a detergentes, "no rafts". Entonces el ABCA1 sería capaz de reorganizar los microdominios de la membrana plasmática y precondiconar la células para que la apoA-I y dHDL adquieran lípidos (Landry y col., 2006). Por otro lado se requiere de una membrana dinámica y fluida, para la formación de HDL nacientes. 


\subsection{Transportador ABCG1}

La actividad traslocasa de lípidos del transportador ABCG1, al igual que el $A B C A 1$, provoca la redistribución de colesterol a nivel de la membrana (Vaughan y Oram, 2005) siendo este principalmente un transportador de colesterol (Oram y Vaughan, 2006; Gelissen y col., 2006). Este transportador interviene en el eflujo de lípidos hacia las $\mathrm{dHDL}$, de tamaño mayor o igual a 96 $\AA$ (Favari y col., 2009). Se ha postulado un trabajo coordinado y sinérgico entre el transportador ABCA1 y ABCG1 (Gelissen y col., 2006; Vaughan y Oram, 2006). No se necesita la co-expresión de ambos transportadores en la misma célula, esto indica que las partículas nacientes pueden remover colesterol adicional, de sitios distantes en células que expresen el ABCG1 (Vaughan y Oram, 2006). La regulación de la expresión del ABCA1 y ABCG1 esta controlada por mecanismos similares .La expresión de ambos transportadores, se vé estimulada por la carga de colesterol o la inducción con hidroxicolesterol y ácido retinoico (fig. 1-3), este hecho soporta aún más el trabajo coordinado de ambos transportadores (Gelissen y col., 2006).

\subsection{ACEPTORES EXTRACELULARES}

\subsection{1 apoA-I}

La apoA-I es el componente proteico mayoritario de las HDL, cumple un rol clave en el TRC, proceso antiaterogénico de gran importancia. Pertenece al grupo de las apolipoproteínas intercambiables, conjuntamente con la apoA-II, IV, Cl, CIII y E y la apolipofirina III de insecto. Los hepatocitos y enterocitos se encargan de sintetizar apoA-I, en la forma de preproapoA-I, que contiene una extensión del dominio $\mathrm{N}$-terminal, constituida por un prepéptido de 18 aminoácidos y un propétido de 6 aminoácidos (Gordon y col., 1983), luego mediante clivaje co-traduccional, se transforma en proapoA-I. En humanos la proapoA-I, se convierte en su forma madura extracelularmente (Bojanovski y col., 1985). 


\subsubsection{Estructura de la apoA-I}

La apoA-I madura, esta constituida por 243 aminoácidos y pesa 28,1kDa. En cuanto a su estructura secundaria, esta formada por repeticiones en tándem, que se predicen $\alpha$-hélices anfipáticas, comprometiendo entre 22 y 11 residuos, separados en su mayor parte por prolina (Segrest y col., 1992).

En la apoA-I se encuentran al menos tres tipos diferentes de hélices anfipáticas, diferenciándose por la distribución particular de sus cargas en la cara polar. En el extremo $\mathrm{N}$-terminal, hay una hélice $\mathrm{G}^{*}$, similar a la de las proteínas globulares, con una distribución al azar de los residuos cargados. Se encuentran seis hélices anfipáticas tipo A (hélices 1,2 y 5 a 8), que son típicas en las apoliporoteínas intercambiables, y que presentan un agrupamiento de cargas positivas en la interfase polar/no polar y de cargas negativas en el centro de la cara polar. ApoA-I presenta además, dos pares de hélices tipo $\mathrm{Y}$, un par en el centro (residuos 88-120, hélices 3 y 4) y otro en la región Cterminal (residuos 209-241, hélices 9 y 10). Este tipo de hélice anfipática, se caracteriza por presentar tres agrupamientos de cargas positivas, que se asemejan a la letra $Y$, con los residuos no polares entre los brazos y residuos negativos entre los brazos y la base de la $\mathrm{Y}$.

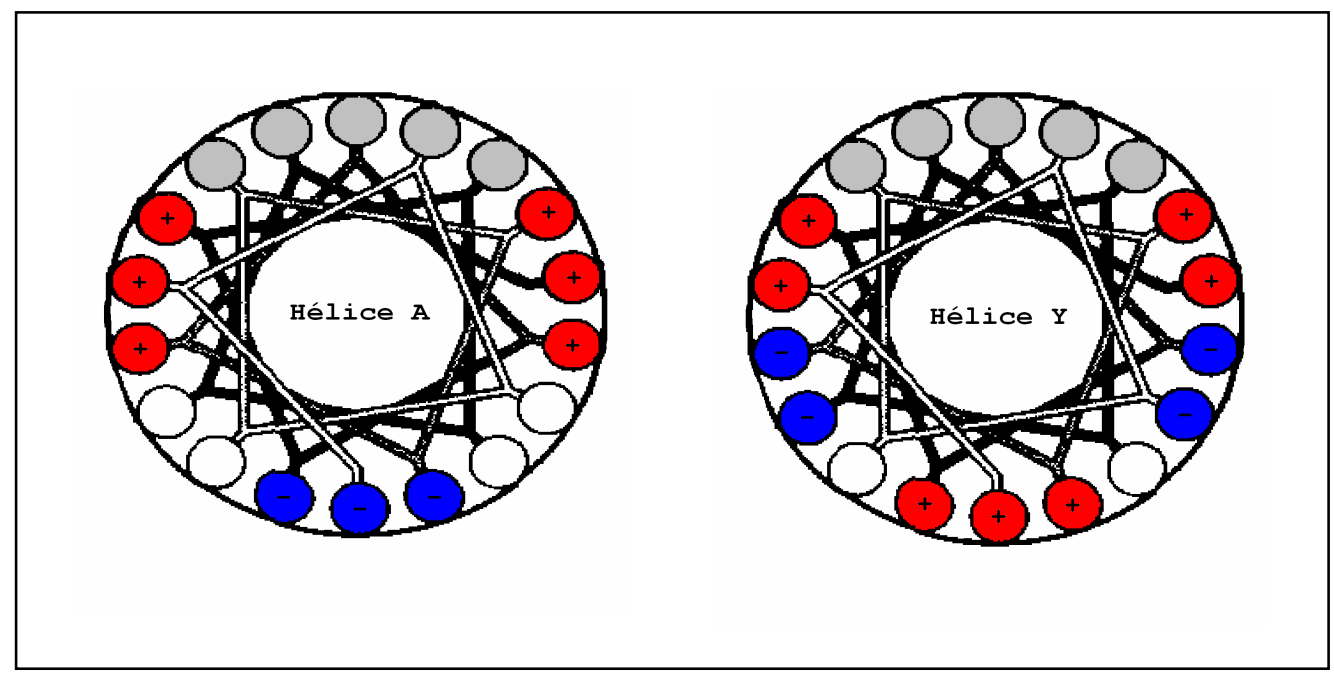

Figura 1-4. Diagramas de ruedas indicando la distribución de residuos cargados en las $\alpha$-hélices anfipáticas tipo A y tipo $\mathrm{Y}$. Los residuos hidrofóbicos se indican en gris y los residuos polares sin carga en blanco. 


\subsubsection{Flexibilidad conformacional de la apoA-I}

La apoA-I presenta una gran flexibilidad conformacional que posibilita su existencia en una gran variedad de estados como libre, pobre en lípidos, unida a membranas o formando complejos lipoproteicos de diferente tamaño y morfología (discoidales o esféricos). Se han planteado diversos modelos conformacionales de la apoA-I en complejos discoidales, como el modelo cerco (Phillips y col., 1997), cinturón (Segrest y col, 1999), hebilla (Tricerri y col., 2001) y doble cinturón, con dos configuraciones posibles $5 / 5$ y $5 / 2$ (Silva y col., 2005). Actualmente el modelo conformacional más aceptado, es el doble cinturón, donde dos moléculas de apoA-I rodean a la bicapa de lípidos del disco de manera antiparalela (Segrest y col., 1999; Silva y col., 2005) como se muestra en la fig. 1-5. La conformación que adopta la apoA-I en complejos discoidales, se relaciona con diversas funciones, como su afinidad por membranas, eflujo de lípidos y activación de LCAT.

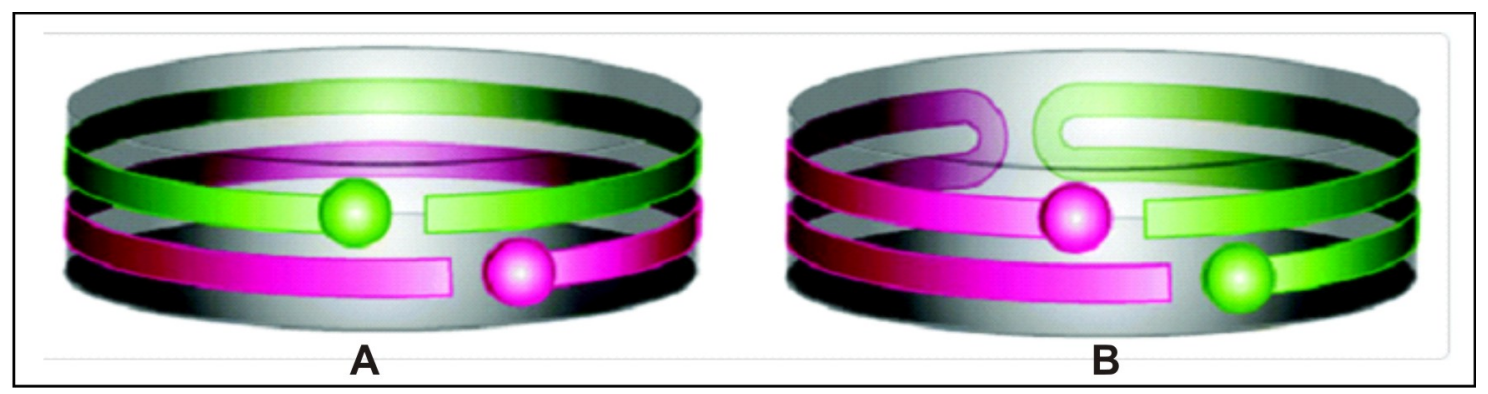

Figura 1-5. A) Modelo de doble cinturón en la configuración LL5/5 (Segrest y col., 1999; Silva y col., 2005) donde dos moléculas de apoA-I rodean la bicapa lipídica de manera antiparalela, B) Modelo de hebilla en la configuración cabeza-cabeza (Tricerri y col., 2001).

\subsubsection{Dominios de la apoA-I}

Se ha postulado que diferentes dominios de la apoA-I, estarían involucrados en la interacción con membranas, eflujo de lípidos y activación de diferentes enzimas como LCAT. En relación a los dominios de la apoA-I, no se conoce con exactitud la función que cumple cada dominio en diferentes procesos, como eflujo de lípidos, interacción con membranas, activación de diferentes vías de señalización entre otros. Sería interesante poder establecer una relación estructura-función de los distintos dominios de la apoA-I, a fin de poder 
diseñar diferentes moléculas terapéuticas, para tratar enfermedades como la aterosclerosis.

\subsection{Dominio N-terminal}

Con respecto al dominio $\mathrm{N}$-terminal, varios autores han sugerido su intervención en el eflujo de lípidos como Vedhachalam y col., (2004), mediante mutantes de deleción de la región $\mathrm{N}$-terminal de la apoA-I, demostraron que el eflujo de colesterol y fosfolípidos se veía reducido en un 30\%. Como así también plantearon que la mutante de deleción $(\Delta 123-166)$ de la región central de la apoA-I, no tiene efecto sobre el eflujo de lípidos en macrófagos $\mathrm{J774}$ y fibroblastos. Por otro lado Gillote y col., (1999) diseñaron péptidos sintéticos, que recorrían toda la secuencia de la apoA-I y comprobaron que la región $\mathrm{N}$ terminal interviene en el eflujo de lípidos, como así también la región Cterminal, con un porcentaje de eflujo del 50 y $70 \%$ respectivamente en fibroblastos humanos.

\subsection{Dominio C-terminal}

Vendhachalam y col, (2004), en su estudio con mutantes demostraron que la región C-terminal también era necesaria para el eflujo de colesterol y fosfolípidos, dado que una deleción de esta región reducía el eflujo de lípidos. Esto también fue sugerido por Gillote y col., (1999), en base a sus estudios con péptidos sintéticos. Por otro lado Panagotopulos y col. (2002) diseñaron mutantes de deleción de la región C-terminal y mutantes puntuales de la hélice 10 y sugirieron que la región C-terminal era importante a nivel del eflujo de lípidos y unión con membranas en células RAW 264.7, como así también que se necesitaba una correcta distribución de las cargas en las hélices para este proceso.

\subsection{Dominio Central}

También existen muchas evidencias de que el dominio central de la apoA-I interviene en el eflujo de lípidos, unión a membranas y activación de LCAT 
(Philippe y Marcel, 2000). Diferentes evidencias de nuestro laboratorio demostraron que contrariamente al resto de las hélices de apoA-I, la región correspondiente al par de hélices $Y$ centrales se inserta profundamente en la membrana con el eje de la hélice perpendicular a la superficie, muy probablemente formando un ramillete intermolecular con la región homóloga de otra molécula de apoA-I (Corsico y col., 2001; Prieto y Garda, 2011).

Mediante la utilización de un péptido sintético, con la secuencia de la región central de la apoA-I (residuos 77-120), se observó que esta promovía el eflujo de colesterol (Toledo y col., 2004) y disminuía el pool de colesterol accesible a ser esterificado por ACAT en células CHO-K1 (Gonzalez y col., 2008).

Por otro lado, se sugirió que un modo de interacción similar podría ocurrir para la interacción entre $\mathrm{HDL}$ discoidales y membranas, que sería relevante para el intercambio de colesterol (y otros lípidos) entre las mismas (Garda, 2007). La capacidad de interactuar (Tricerri y col., 1998) e intercambiar colesterol (Toledo y col., 2000) con membranas es dependiente del tamaño y contenido de colesterol de las dHDL. Es posible que estos factores modulen la formación del ramillete intermolecular o dominio de inserción activo, y por tanto la interacción e intercambio lipídico con la membrana.

\subsubsection{HDL}

Las HDL representan una población heterogénea de lipoproteínas de alta densidad ( $\mathrm{d}=1,063-1,21 \mathrm{~g} / \mathrm{ml}$ ) de forma discoidal o esférica, cuyo componente apolipoproteíco mayoritario es la apoA-I (aproximadamente el 70\%) (Rader, 2006). Se encuentran subpoblaciones de HDL que difieren en sus propiedades fisicoquímicas como actividades biológicas (Barter y col., 2003).

Las HDL discoidales (dHDL) o pre- $\beta$ HDL juegan un rol fundamental al inicio del TRC. Están constituidas por una bicapa superficial de fosfolípidos y colesterol no esterificado, más las apolipoproteínas. Presentan dos o más moléculas de apoA-I por disco (Rye y col., 2009). Las HDL esféricas predominan en el 
plasma humano y están formadas por una monocapa de fosfolípidos y un núcleo hidrofóbico con alto contenido en CE y TG (Kontush y col. ,2006).

\subsubsection{Clasificación}

Las HDL se pueden clasificar (fig.1-4.), según distintos patrones como A) la forma, B) la densidad, C) el diámetro, D) la composición en apolipoproteínas AI y A-II, E) la movilidad electroforética y F) el tamaño en orden descendente.

A) Según su forma se encuentran HDL discoidales (nacientes) y HDL esféricas (maduras).

B) En función de la densidad se encuentran: $\mathrm{HDL}_{2}(\mathrm{~d}=1,063-1,125 \mathrm{~g} / \mathrm{ml} ; 60 \%$ lípidos y $40 \%$ proteínas) y $\mathrm{HDL}_{3}(\mathrm{~d}=1,125-1,210 \mathrm{~g} / \mathrm{ml} ; 45 \%$ lípidos y $55 \%$ proteínas).

C) En base a su tamaño las HDL esféricas se pueden dividir en cinco subpoblaciones de partículas en un rango de 10,6 nm a 7,6 nm de diámetro.

D) Según la composición en apolipoproteínas, se las clasifica en: LpA-I, LpA-II, LpA-I/LpA-II, y-LpE y LpA-IV.

E) Según su movilidad electroforética en: $\alpha-H D L$ (HDL esféricas y LpA-IV), pre $\beta$-HDL (HDL discoidales y apoA-I libre); y y-HDL ( $y-L p E)$.

F) Según el tamaño en orden descendente: $\mathrm{HDL}_{2 b}, \mathrm{HDL}_{2 a}, \mathrm{HDL}_{3 a}, \mathrm{HDL}_{3 b}$ y $\mathrm{HDL}_{3 \mathrm{c}}$. 


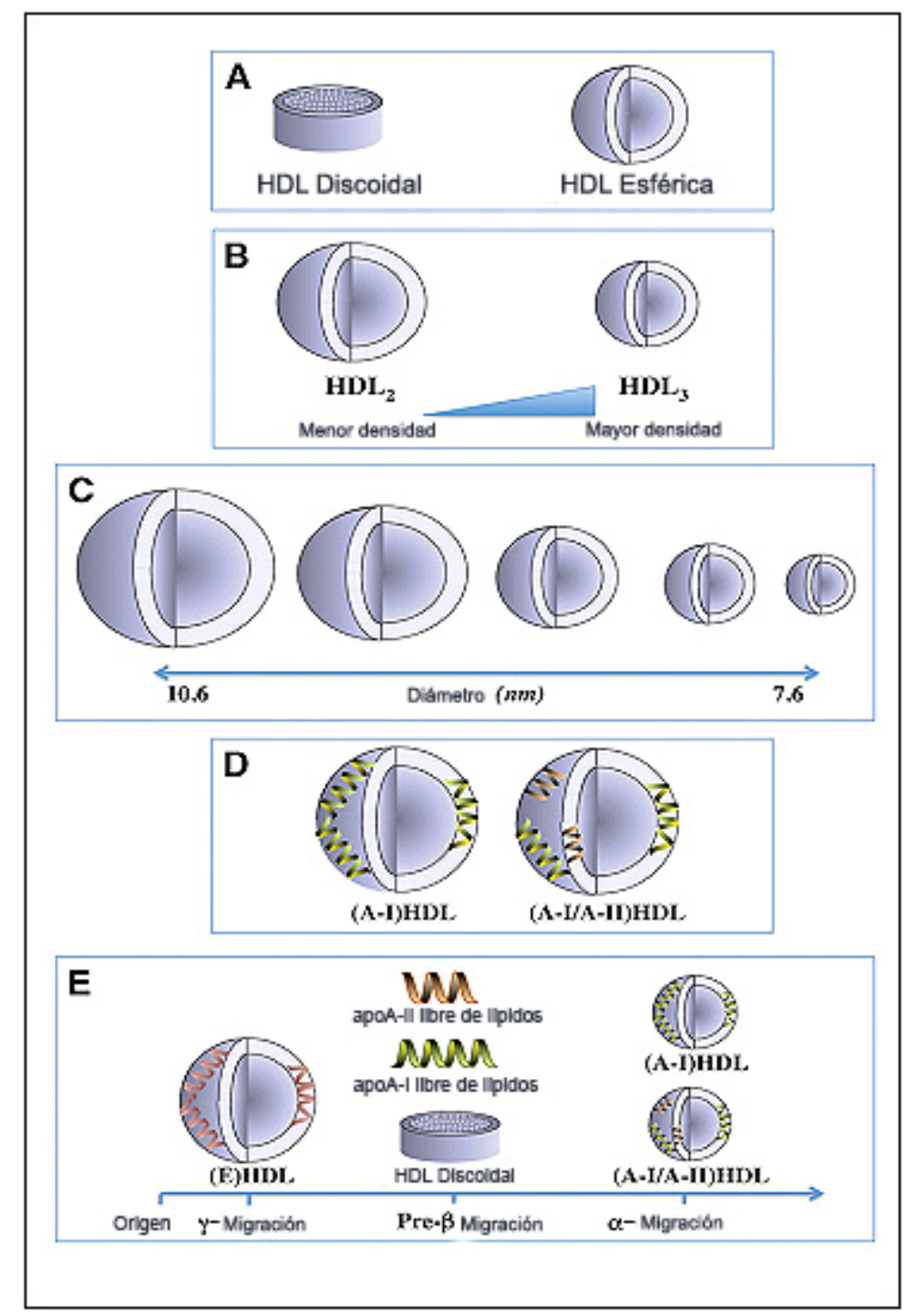

Figura. 1-6. Heterogeneidad de las subpoblaciones de HDL (Rye y col., 2009 con modificaciones). Clasificación de las partículas según A) la forma, B) la densidad, C) el diámetro, D) la composición en apoA-I y A-II y E) la movilidad electroforética.

\subsubsection{Síntesis HDL}

La apoliporoteína mayoritaria de las HDL es la apoA-I, se sintetiza a nivel del hígado e intestino. Desde allí es secretada como apoA-I libre o pobre en lípidos, que adquiere rápidamente fosfolípidos y colesterol vía transportador ABCA1 (Oram y col., 2000). De esta manera se forman las HDL discoidales (nacientes). Las dHDL interaccionan con membranas, remueven fosfolípidos y colesterol vía los transportadores ABCA1 y ABCG1, en células cargadas con colesterol (Adorni y col., 2007). Las HDL discoidales de diferente composición y tamaño, presentan distintas capacidades de activación de la enzima LCAT, las dHDL de $78 \AA$ muestran una menor capacidad de activación, en relación a las de $96 \AA$ (de Beer y col., 2001). Con respecto a las dHDL de tamaño mayor, 130 
y $170 \AA$, que contienen más de dos moléculas de apoA-I por disco, ha sido reportado que son mejores activadores de LCAT, en comparación con las dHDL de $96 \AA$ (Cavigiolio y col., 2008). Por otro lado existiría una relación directa entre el tamaño de las dHDL, contenido de apoA-I y la activación de LCAT. La enzima LCAT se encarga de madurar las dHDL, esterifica el colesterol y forma un núcleo hidrofóbico dentro de la lipoproteína, convirtiendo las HDL discoidales en HDL esféricas. Además favorece la formación de un gradiente de concentración de colesterol desde la membrana plasmática u otras lipoproteínas, hacia las HDL esféricas.

En la actualidad no se conoce completamente el mecanismo de interacción y eflujo de lípidos vía apoA-I y dHDL, como así tampoco los transportadores involucrados en este proceso. Múltiples investigaciones están dirigidas a tratar de dilucidar estos procesos, siendo que las $\mathrm{rHDL}$, apoA-I, transportadores de membrana y LCAT son considerados moléculas dianas útiles para la aplicación de terapias farmacológicas.

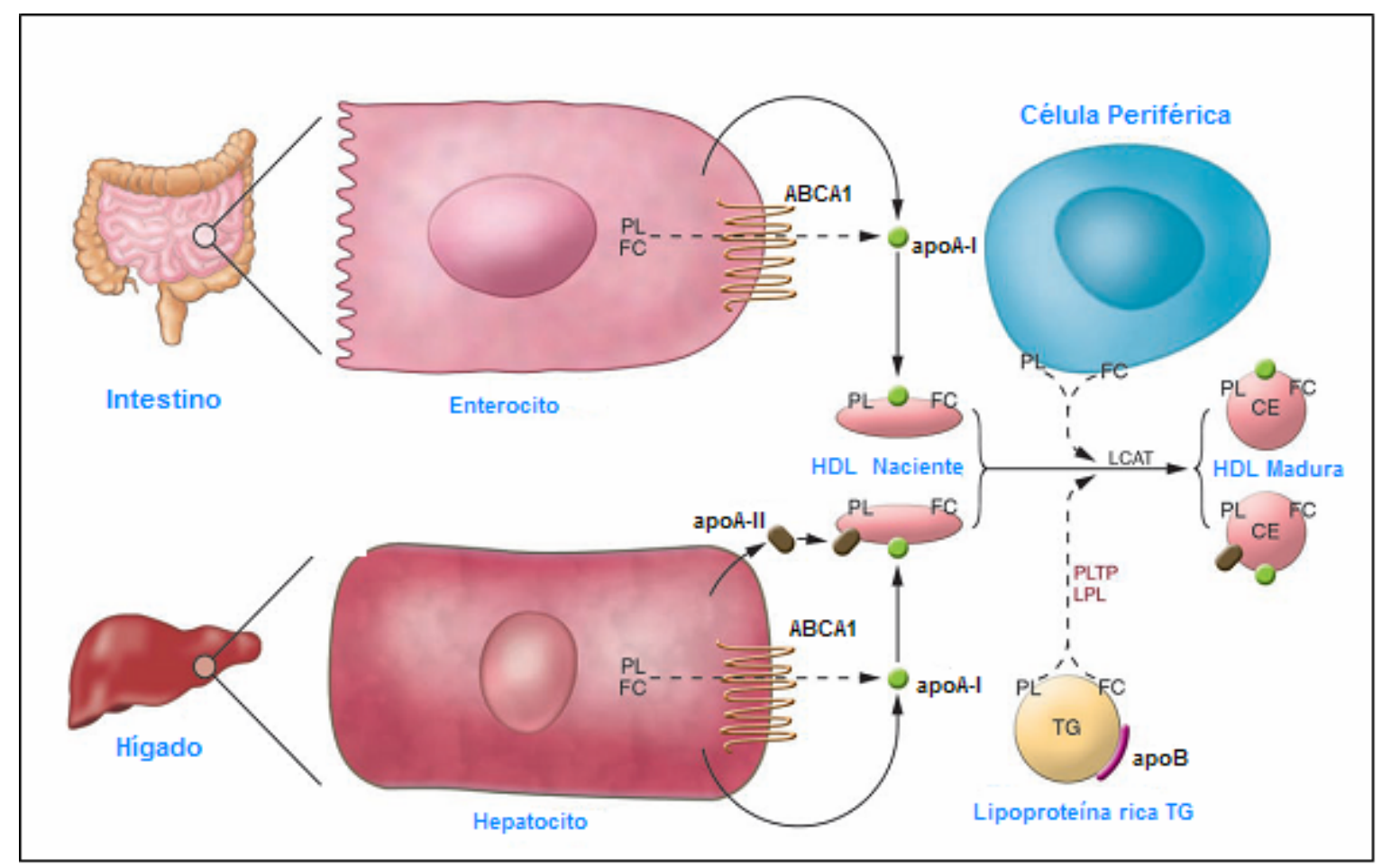

Figura 1-7. Síntesis HDL (Rader, 2006 con modificaciones). Los enterocitos y hepatocitos sintetizan apoAI, que es secretada en su forma pobre en lípidos e inmediatamente se carga de fosfolípidos y colesterol vía transportador ABCA1, formando las HDL nacientes. Las HDL nacientes adquieren más lípidos de células periféricas y de lipoproteínas y la enzima LCAT esterifica el colesterol convirtiéndolas en HDL maduras. 


\section{CAPÍTULO 2.}

HIPÓTESIS Y OBJETIVOS 


\section{CAPÍTULO 2. HIPÓTESIS Y OBJETIVOS}

La apoA-I cumple un rol muy importante en el TRC, es el componente mayoritario de las HDL que desempeñan diversas funciones en las distintas etapas del TRC. Resultados previos de este laboratorio permiten postular la hipótesis de que la región central de la apoA-I, formada por el par de hélices tipo Y, estaría involucrada en la interacción con la membrana celular, que sería importante para el eflujo de lípidos y la movilización de depósitos intracelulares de colesterol (como el disponible a ser esterificado por ACAT) hacia la membrana plasmática. Como la conformación del dominio central es influenciada por el tamaño y composición lipídica (contenido de colesterol) de las HDL, también se postula que esto podría modular la capacidad de interacción con la membrana celular y el consecuente eflujo lipídico.

El objetivo general de este trabajo fue someter a prueba esta hipótesis y aportar información relevante para entender los mecanismos implicados en las etapas iniciales del TRC, como en la interacción de las HDL con membranas celulares y el eflujo celular de lípidos.

Como objetivos específicos, nos propusimos:

1) Reconstituir partículas discoidales HDL similares a las pre- $\beta-H D L$ del plasma, de diferente composición y tamaño, mediante la técnica de diálisis con el detergente colato. Estas fueron comparadas en cuanto a su capacidad de unirse a la membrana celular, y de promover el eflujo de colesterol y fosfolípidos de dos líneas celulares diferentes: CHO-K1 (células de ovario de hámster chino) y RAW 264.7 (macrófagos murinos).

2) Estudiar en comparación con apoA-I salvaje, la funcionalidad y las respuestas celulares a dos mutantes de deleción de un residuo de lisina en las regiones de hélices tipo Y: una con la deleción en la región central de la hélice 4 ( $\Delta$ K 107) y la segunda con la deleción en la posición homóloga de la hélice 10 $(\Delta K 226)$. La primera de estas mutantes es una variante natural cuyos portadores presentan un metabolismo alterado de las HDL e incrementado riesgo aterogénico, por lo que los resultados de estos estudios también podrían ayudar a la comprensión de los síntomas presentados por estos pacientes. Es 
de esperar que estas mutaciones desplacen en $\sim 100^{\circ}$ la orientación relativa entre las caras hidrofílica e hidrofóbica de la hélice anfipática a ambos lados de la mutación, lo que puede afectar tanto la interacción con lípidos como con los receptores celulares. 


\section{CAPÍTULO 3.}

MATERIALES Y MÉTODOS 


\section{CAPÍTULO 3. MATERIALES Y MÉTODOS}

\subsection{OBTENCIÓN DE APO A-I}

\subsubsection{Obtención de apoA-I de suero humano}

La apoA-I fue obtenida a partir de plasma humano (donado por el Banco de sangre del Instituto de Hemoterapia de La Plata). El plasma fue descongelado y se llevó a densidad de 1,21 g/ml con BrNa. Luego se ultracentifugó a 55.000 rpm durante $44 \mathrm{~h}$ a $10^{\circ} \mathrm{C}$. Se recolectó la fracción superior que contenía las lipoproteínas (fig. 3-1). Luego mediante cromatografía en columna abierta (Sephacril S300), se separaron las diferentes lipoproteínas VLDL, LDL y HDL en ese orden. Se tomó la fracción de HDL, y se liberó de lípidos con guanidina HCL $6 \mathrm{M}$ en agitación y a baño maría a $37^{\circ} \mathrm{C}$ durante $3 \mathrm{~h}$. Seguidamente se dializó la muestra con membranas de corte 12.000 d contra EDTA 5 mM. Luego se llevó a densidad $1,21 \mathrm{~g} / \mathrm{ml}$ con BrNa y se ultracentrifugó a $50.000 \mathrm{rpm}$ durante $24 \mathrm{~h}$ a $10^{\circ} \mathrm{C}$. Se obtuvieron dos fracciones u na rica en apoA-Il y otra en apoA-I. Se colectó la fracción rica en apoA-I y se dializó contra $\mathrm{NH}_{4} \mathrm{CO}_{3} \mathrm{H} 5$ $\mathrm{mM}$. Seguidamente se liofilizó la muestra y se guardó a $-80^{\circ} \mathrm{C}$. Con el fin de purificar la apoA-I de la muestra, se disolvió el liofilizado en buffer de elusión (Tris $10 \mathrm{mM}, 1 \% \beta$-mercapto etanol (BME), guanidina $\mathrm{HCL} 3 \mathrm{M}, \mathrm{pH}$ 8), a una concentración de proteína de $50 \mathrm{mg} / \mathrm{ml}$ y se filtró por gel en columna (Superdex 200 10/30 HR). El BME mejora la separación de la apoA-II contaminante, ya que reduce el puente disulfuro y la convierte en su forma monomérica. Luego se colectaron las fracciones conteniendo apoA-I y se dializó contra buffer EDTA 0,01\% pH 7,5. Finalmente se liofilizó la apoA-I y guardó a $-80^{\circ} \mathrm{C}$ hasta su uso (Tricerri y col., 1998) . La proteína mostró más de un $95 \%$ de pureza, estimado por electroforesis en gel de poliacrilamida al $12 \%$ en presencia de SDS. 


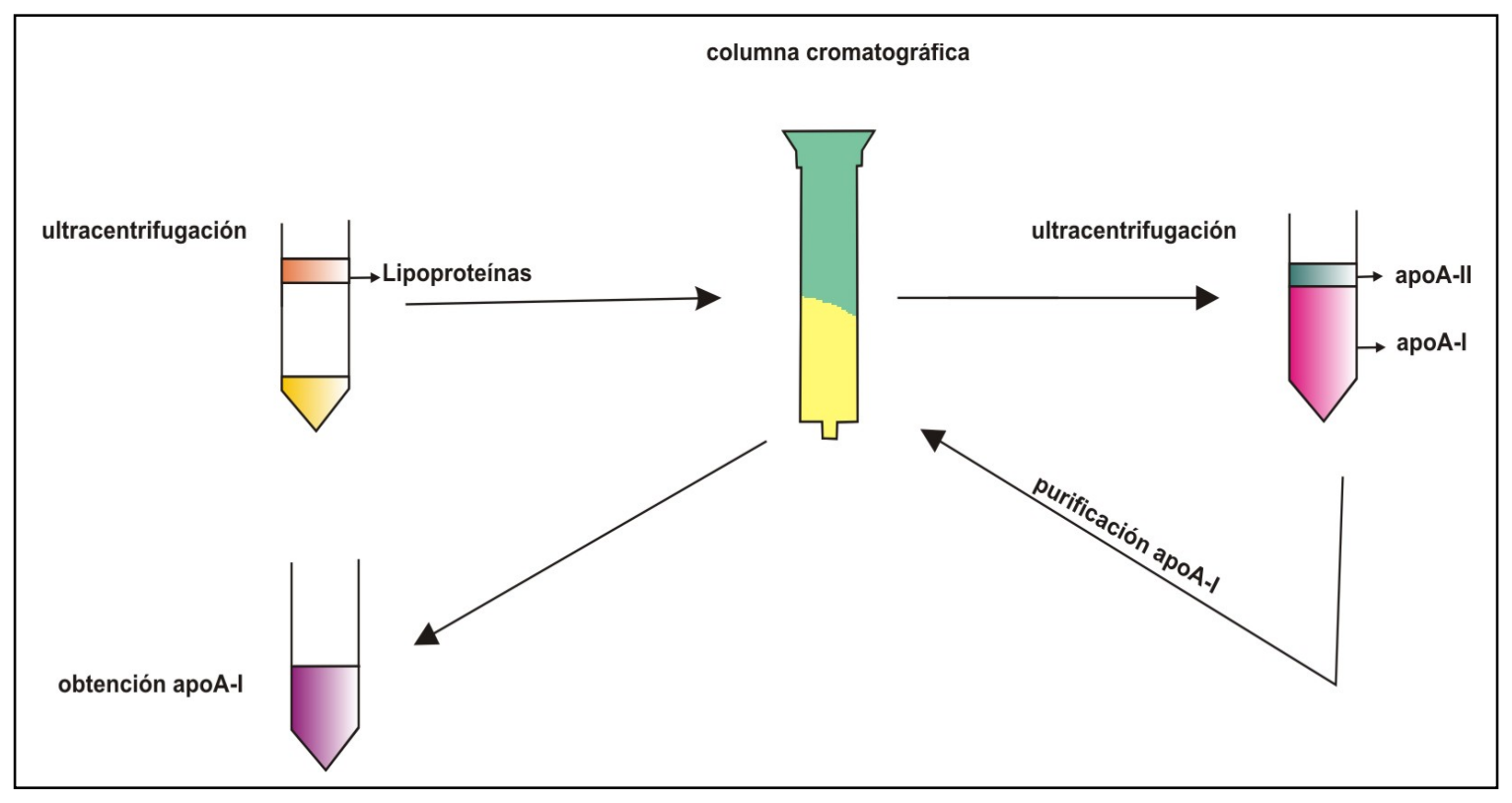

Figura 3-1 Obtención de apoA-I de suero. El plasma fue sometido a ultracentrifugación a $55.000 \mathrm{rpm}$ durante $44 \mathrm{~h}$ a $10^{\circ} \mathrm{C}$. Luego se colectó la fracción superior que contenía las lipoproteínas (HDL, LDL, VLDL) y se separaron mediante columna cromatográfica (Sephacril S300). La fracción que contenía las $\mathrm{HDL}$, fue tratada con guanidina $\mathrm{HCl} 6 \mathrm{M}$ con el fin de liberarla de lípidos y luego se ultracentrifugó a $50.000 \mathrm{rpm}$ durante $24 \mathrm{~h}$ a $10^{\circ} \mathrm{C}$. Se obtuvieron dos fracciones una rica en apoA-Il y otra en apoA-I. La fracción rica en apoA-I se purificó mediante columna cromatográfica (Superdex 200 10/30 HR). Finalmente se colectó la apoA-I, liofilizó y guardó a -80C.

\subsubsection{Obtención de apoA-I salvaje a partir de bacterias}

EI cADN de la pro-apoA-I, fue insertado en un vector de clonación plasmídico pET30, nos fue donado por la Dra. Ana Jonas (Urbana, IL, USA). El polilinker o sitio múltiple de clonado de este plásmido, incorpora directamente a la región traducida del gen, una secuencia de polihistidina, en la región $\mathrm{N}$-terminal de la proteína, facilitando su posterior detección y purificación. En el pET30 original (fig. 3-2), la expresión de un sitio reconocido por enteroquinasa permite el clivaje y eliminación de la secuencia poli-His. Por motivos de practicidad y económicos, en nuestro laboratorio se ha introducido al cADN una mutación puntual (Glu por Asp) en la segunda posición de la secuencia de apoA-I (Prieto y col., 2012). Esto crea un enlace Asp-Pro lábil en medio ácido que permite eliminar la cola de polihistidina por tratamiento con ácido fórmico. 

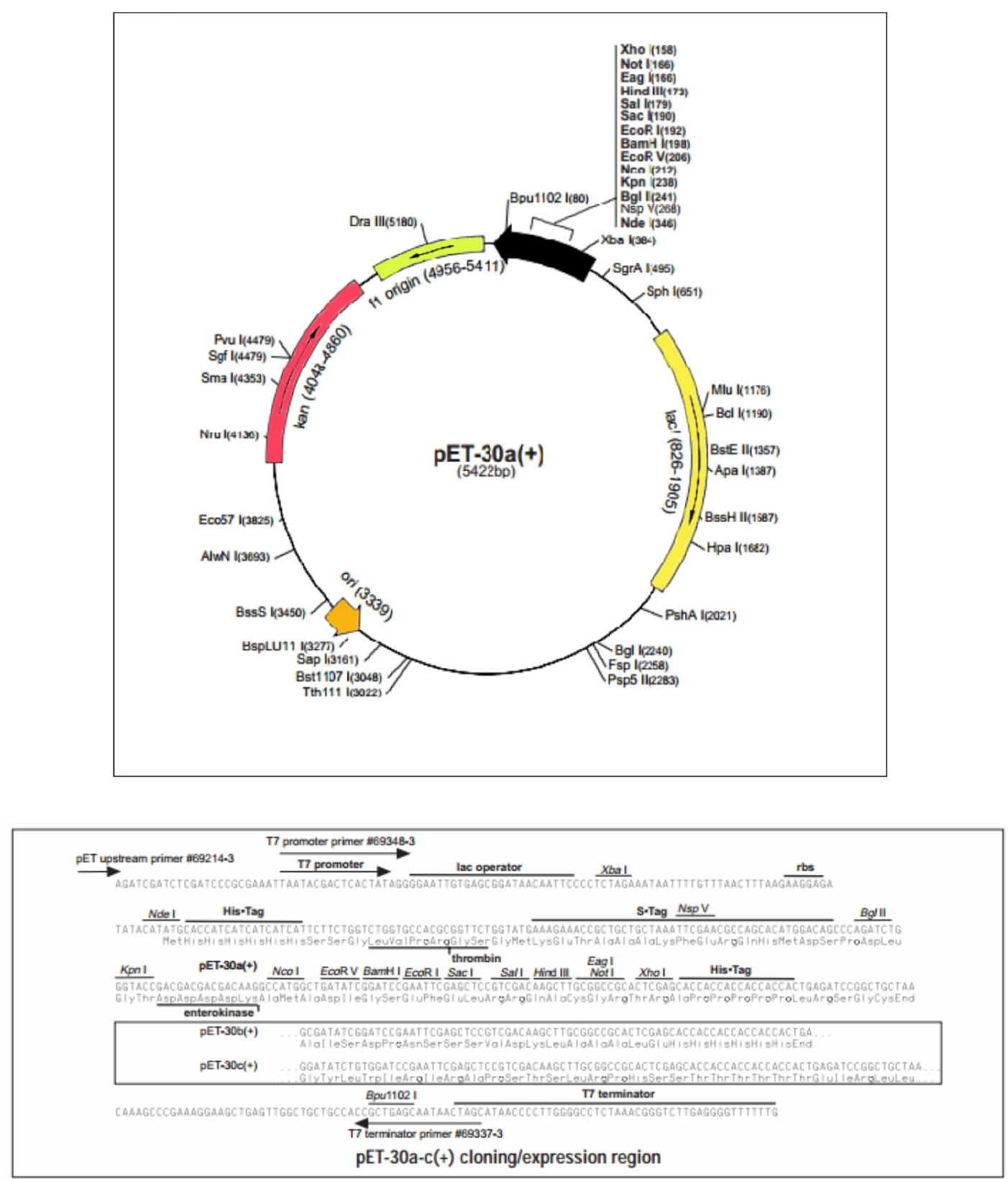

Figura 3-2. Descripción del plásmido pET 30 (Novagen) y del sitio múltiple de clonado.

\subsection{CONSTRUCCIÓN DE MUTANTES $\Delta K 226$ y $\Delta$ K107}

Para la mutagénesis sitio-dirigida (fig.3-3) se usó el kit Quick-Change de Stratagen como se ha descripto en trabajos previos del grupo Gonzalez y col., 2008 y Prieto y col., 2012. 


\section{Mutagénesis sitio dirigida}

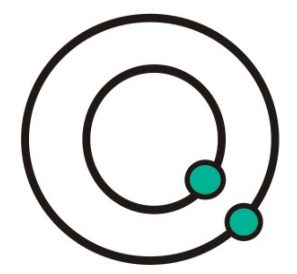

Plásmido con el gen de la apoA-I con el sitio diana

para introducir la mutación deseada

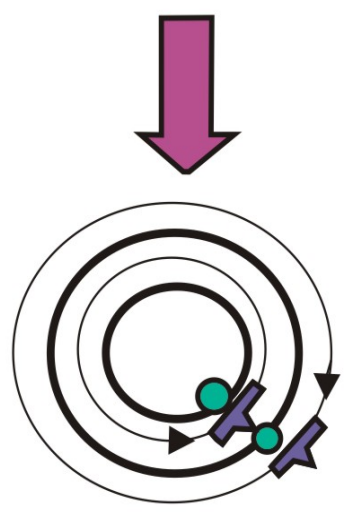

Reacción de PCR con los oligonuclótidos mutado

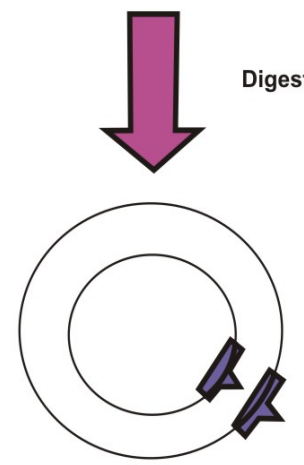

Digestión de la hebra parental metilada con Dpnl

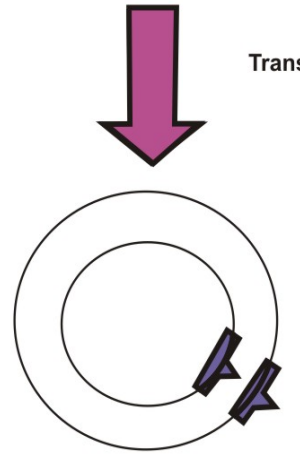

Plásmido con la mutación deseada

Las bacterias luego de la transformación reparan los cortes y metilan el plásmido circular

Figura 3-3. Descripción de la técnica Mutagénesis sitio dirigido. 


\subsubsection{Construcción de la mutante $\Delta \mathrm{K} 226$}

\subsubsection{Diseño de primers}

Los primers se diseñaron siguiendo el protocolo del kit y para su síntesis se usó el servicio de Macrogen (Corea). Las secuencias se detallan a continuación:

\section{Primers foward: 5'-GCTGGAGAGCTTCGTCAGCTTCCTGAGC-3'}

Primera reverse: 5'-GCTCAGGAAGCTGACGAAGCTCTCCAGC-3'

$\mathrm{Tm}=84,74^{\circ} \mathrm{C}$

Estos primers se usaron para las reacciones de PCR utilizando como molde al plásmido entero conteniendo el inserto de apoA-I tipo salvaje ya modificado para contener el sitio de clivaje para ácido fórmico. Seguidamente en la tabla 31 se muestran los reactivos utilizados para la reacción de PCR.

Tabla 3-1. Reactivos utilizados para PCR mutagénesis sitio dirigido construcción mutante $\Delta$ K226. El control se realizó sin Pfu polimerasa.

\begin{tabular}{|l|c|l|}
\hline & Enzima & Control \\
\hline $\mathrm{H}_{2} \mathrm{O}$ MilliQ & $39 \mu \mathrm{l}$ & $40 \mu \mathrm{l}$ \\
\hline Buffer $(10 \mathrm{X})$ & $5 \mu \mathrm{l}$ & $5 \mu \mathrm{l}$ \\
\hline Primers $\Delta \mathrm{K} 226$ & $1 \mu \mathrm{l}$ & $1 \mu \mathrm{l}$ \\
\hline Primers $\Delta \mathrm{K} 226$ & $1 \mu \mathrm{l}$ & $1 \mu \mathrm{l}$ \\
\hline dNTP(25 mM) & $1 \mu \mathrm{l}$ & $1 \mu \mathrm{l}$ \\
\hline Molde apoA-Isalvaje & $2 \mu \mathrm{l}$ & $2 \mu \mathrm{l}$ \\
\hline Pfu polimerasa & $1 \mu \mathrm{l}$ & $0 \mu \mathrm{l}$ \\
\hline Total & $50 \mu \mathrm{l}$ & $50 \mu \mathrm{l}$ \\
\hline
\end{tabular}

\subsubsection{Ciclos PCR}

Los ciclos de temperatura programados para la PCR Mutagénesis sitio dirigido, se muestran a continuación en la tabla 3-2.

Tabla 3-2 Ciclos de temperatura, mutagénesis sitio dirigido construcción variante $\Delta \mathrm{K} 226$.

\begin{tabular}{|r|l|l|c|}
\hline Segmento & Ciclos & Temperatura & Tiempo \\
\hline 1 & 1 & $95^{\circ} \mathrm{C}$ & $30 \mathrm{~s}$ \\
\hline 2 & 16 & $95^{\circ} \mathrm{C}$ & $1 \mathrm{~min}$ \\
& & $55^{\circ} \mathrm{C}$ & $1 \mathrm{~min}$ \\
& & $70^{\circ} \mathrm{C}$ & $13 \mathrm{~min}$ \\
\hline
\end{tabular}


Para controlar la amplificación del producto de PCR se realizó un gel de agarosa al 0,8\% (sección 3.5.2).

\subsubsection{Precipitación con etanol}

Con el fin de purificar el ADN de contaminantes, se realiza la precipitación con etanol en frío. El etanol aísla el ADN provocando la precipitación del mismo libre de contaminantes, que se recupera por centrifugación. A la muestra se le agregaron 2,5 volumenes de etanol 96\%, 0,1 volumenes de solución de acetato de sodio $3 \mathrm{M}, \mathrm{pH} \mathrm{5,2}$ y se incubó a $-20^{\circ} \mathrm{C}$ durante 15-30 min. Después se centrifugó a 14.000 rpm durante 20 min, se descartó el sobrenadante y se lavó con alcohol al $70 \%$. Nuevamente se centrifugó a $14.000 \mathrm{rpm}$ durante $5 \mathrm{~min}$, se lavó el pellet con alcohol $70 \%$ y luego se secó con vacío.

\subsubsection{Corte con Dpnl}

A fin de digerir el molde de ADN (plásmido con el inserto sin la mutación), se trató al producto de PCR, con la enzima Dpnl $10 \mathrm{U} / \mu \mathrm{l}$ durante $1 \mathrm{~h}$ a $37^{\circ} \mathrm{C}$. Esta nucleasa es específica para el ADN metilado (plásmido molde proveniente de bacterias), dejando intacto al ADN no metilado generado por la PCR que contiene la mutación. El producto de PCR tratado con Dpnl fue utilizado para transformar bacterias Escherichia coli (E.coli) JM109 competentes, como se describe en la sección 3.3.3.

\subsubsection{Construcción Mutante $\Delta \mathrm{K} 107$}

\subsubsection{Diseño de primers}

Al cADN de esta mutante en pET30 (también donado por A. Jonas), se le introdujo el sitio de clivaje en medio ácido, por mutagénesis sitio-dirigida con el kit Quick-Change de Stratagene utilizando los siguientes primers:

\section{Primer Foward: 5'-GGCAGCAAGATGATCCCCCCCAGAGCCCC-3' Primer Reverse: 5'-GGGGCTCTGGGGGGGATCATCTTGCTGCC-3'}

Todos los procedimientos seguidos para la realización de la PCR, extracción y purificación del ADN plasmídico, como la transformación de bacterias JM109 y 
BL21 de la mutante $\Delta \mathrm{K} 107$, fueron similares a los descriptos para la mutante $\Delta \mathrm{K} 226$ en la sección 3.2.1.

\subsection{PROTOCOLOS GENERALES DE TRABAJO CON BACTERIAS}

Como hospedador bacteriano se utilizó E.coli, debido a que presenta varias ventajas con respecto a otros hospedadores: elevada velocidad de crecimiento, fácil manipulación genética, alta eficiencia en incorporación de ADN foráneo y bajo costo económico. En este trabajo se utilizaron dos cepas distintas de E.coli: BL21 hospedador de expresión y JM109 hospedador de expansión. Las cepas BL21 y JM109 presentan modificaciones genéticas, que las hace aptas para la expresión y expansión respectivamente. En el caso de la cepa BL21, no expresa ciertas proteasas, que podrían degradar la proteína recombinante durante la purificación, y además es fácilmente inducible con lactosa o isopropil- $\beta$-D-1-tiogalactopiranósido (IPTG). En el caso de la cepa JM109, esta diseñada de manera tal que la tasa de recombinación sea mínima, confiriéndole una alta estabilidad a los plásmidos.

\subsubsection{Medios de cultivo}

Las bacterias se cultivaron en medio Luria- Bertani (LB) como medio líquido y como medio sólido, LB con un 1,5\% p/v de agar (LB agar).

\subsubsection{Preparación de bacterias competentes (método de Hanahan)}

En células bacterianas, se puede inducir la competencia para la incorporación de los plásmidos. Esta consiste en crecer las células en medio LB, colectarlas durante el crecimiento exponencial y resuspenderlas en una solución fría de $\mathrm{CaCl}_{2}$. El tratamiento con $\mathrm{CaCl}_{2}$ es muy importante ya que neutraliza las cargas de ADN y fosfolípidos, permitiendo la adsorción del ADN a la membrana plasmática de la bacteria, haciéndola de esta manera más permeable. En cuanto al procedimiento, se inocularon $100 \mathrm{ml}$ de medio LB sin antibiótico, con las bacterias de interés. Se las dejo crecer en agitación a $22^{\circ} \mathrm{C}$, hasta llegar a una $\mathrm{DO}_{600 \mathrm{~nm}}$ aproximadamente de 0,55. Luego el inóculo fue incubado en hielo por 10 min, con el fin de disminuir la fluidez de la membrana, y se le agregó 32 
$\mathrm{ml}$ de solución de competencia $\left(\mathrm{MnCl}_{2} .4 \mathrm{H}_{2} \mathrm{O} 1,088 \% \mathrm{p} / \mathrm{v} ; \mathrm{CaCl}_{2} 2 \mathrm{H}_{2} \mathrm{O}\right.$ 0,22\% $\mathrm{p} / \mathrm{v}$ : $\mathrm{KCl} 1,865 \% \mathrm{p} / \mathrm{v}$; Pipes $0,01 \mathrm{M})$. Luego las células bacterianas se recolectaron por centrifugación a $4.000 \mathrm{rpm}$ por $10 \mathrm{~min}$ y fueron resuspendidas en $8 \mathrm{ml}$ de solución de competencia con un 7\% v/v DMSO y se las dejó en frío por $10 \mathrm{~min}$. Luego fueron alicuotadas y congeladas a $-80{ }^{\circ} \mathrm{C}$ en stock de glicerol al 15\%, como se explica en la sección 3.3.4.

\subsubsection{Transformación de bacterias competentes}

La transformación es uno de los mecanismos mediante el cual las bacterias intercambian el material genético entre individuos de la misma especie e incluso entre distintas especies. Adquieren el ADN proveniente del medio extracelular y en el caso de los plásmidos, estos quedan como elementos replicativos autónomos dentro de la célula. Para realizar la transformación, las bacterias tienen que estar en estado de competencia. La transformación de las bacterias competentes se lleva a cabo mediante choque térmico (Hanahan, 1983). Se utilizaron $200 \mu \mathrm{l}$ de bacterias competentes, las cuales fueron transformadas con $10 \mu \mathrm{l}$ de plásmidos mediante shock térmico. Este consistió en incubarlas en hielo por 45 a 60 min luego transferirlas a un baño térmico a $42^{\circ} \mathrm{C}$ durante $45 \mathrm{~s}$ exactos, con agitación constante. Inmediatamente después ponerlas en hielo por 2 min y agregarles $800 \mu \mathrm{l}$ de medio nutritivo enriquecido con glucosa (Soc). Finalmente se las incubó a $37^{\circ} \mathrm{C}$ por $1 \mathrm{~h}$. La selección de las bacterias transformadas se realizó en base a su resistencia al antibiótico kanamicina, de esta manera se seleccionan los subclones. Se prepararon placas con medio LB-Agar con antibiótico kanamicina, se realizaron estriaciones en las placas y se las incubó a $37^{\circ} \mathrm{C}$ durante $24 \mathrm{~h}$. Luego se observó el crecimiento de bacterias transformadas con el plásmido de interés que presenta resistencia a la kanamicina (fig. 3-4). 


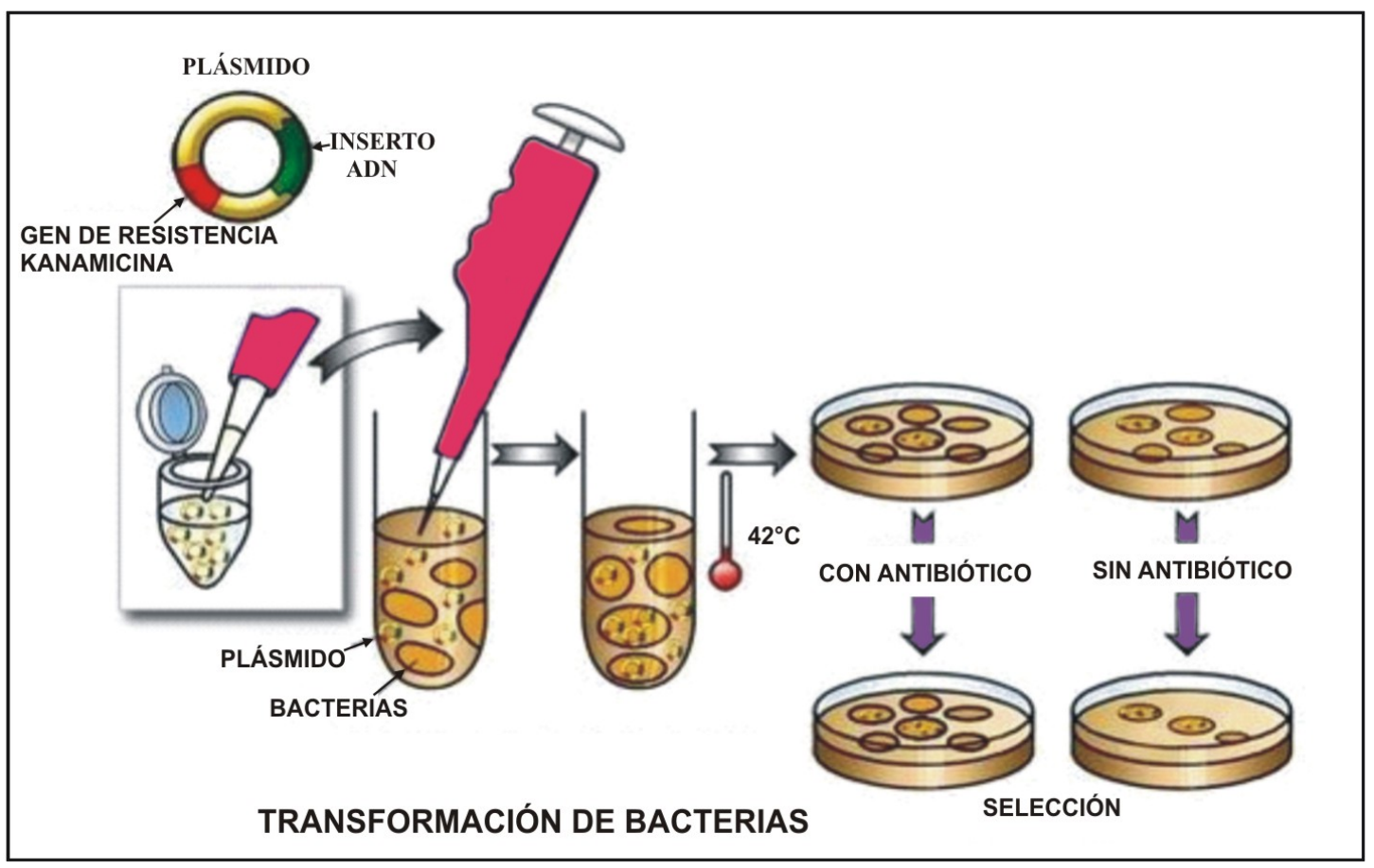

Figura 3-4. Transformación de bacterias competentes.

\subsubsection{Conservación de bacterias}

Con el fin de conservar las bacterias por largos períodos de tiempo a $-80^{\circ} \mathrm{C}$, se las almacenó en un stock de glicerol, que contiene medio de cultivo con bacterias y un $15 \%$ de glicerol.

\subsection{PROTOCOLOS GENERALES DE TRABAJO CON ADN}

\subsubsection{Minipreparación de Plásmidos}

Este método se utiliza para obtener ADN plasmídico en pequeña cantidad (en el orden de los microgramos) y se basa en la lisis alcalina en presencia de dodecil sulfato de sodio (SDS), de esta manera se rompe la pared celular, se desnaturaliza el ADN cromosómico y las proteínas, liberándose el ADN plasmídico. Para la extracción del ADN plasmídico las células bacterianas fueron tratadas con tres soluciones distintas, una solución de resuspensión (Tris- $\mathrm{HCl}$ 0, 25 mM; EDTA 10 mM, pH 8, 0) mediante la cual se resuspenden las bacterias a un $\mathrm{pH} 8$ y se quelan ciertos iones de $\mathrm{Ca}^{+2} \mathrm{y} \mathrm{Mg}^{+2}$, con el fin de que estos cofactores no estén disponibles para Dnasas, una solución de lisis 
( $\mathrm{NaOH}$ 0,2 M; SDS 1\%), donde el incremento del pH combinado con la acción del detergente SDS genera la desnaturalización de proteínas y de ADN cromosómico, provocando de esta manera la ruptura de la pared celular; y por último una solución de renaturalización $(60 \mathrm{ml}$ de acetato de potasio $5 \mathrm{M}, 11,5$ $\mathrm{ml}$ de ácido acético, y $100 \mathrm{ml}$ de agua destilada) donde el cambio de los iones de $\mathrm{Na}^{+}$por $\mathrm{K}^{+}$provoca la precipitación de los complejos formados por SDSproteínas y ADN cromosómico. Luego el sobrenadante es sometido a una mezcla de fenol:cloroformo $(1: 1 \mathrm{v} / \mathrm{v})$ para precipitar el resto de las proteínas. Finalmente el ADN plasmídico se concentra y purifica mediante precipitaciones alcohólicas combinadas con la disminución de la temperatura. Luego el ADN se recupera, por sucesivas centrifugaciones a alta velocidad.

Se partió de 1,2 ml de medio de cultivo con las bacterias de interés, que fueron centrifugadas a $12.000 \mathrm{rpm}$ durante $1 \mathrm{~min}$. Al pellet se le agregó $100 \mu \mathrm{l}$ de solución de resuspensión. Luego se adicionaron $200 \mu$ de la solución de lisis, se mezcló por inversión hasta disolver el pellet y se incubó 5 min a temperatura ambiente. Para finalizar con la extracción se agregaron $150 \mu \mathrm{l}$ de la solución de renaturalización, se lo dejo en hielo durante $5 \mathrm{~min}$, para favorecer la formación del precipitado, se centrifugó a 12.000 rpm durante $5 \mathrm{~min}$. Al sobrenadante, con el ADN plasmídico, se le agregó $450 \mu \mathrm{l}$ de fenol:cloroformo $(1: 1 \mathrm{v} / \mathrm{v})$ y se centrifugó a 12.000 rpm durante 5 min. Luego se adicionaron 2,5 volumenes de etanol $96 \%, 0,1$ volumenes de solución de acetato de sodio $3 \mathrm{M}, \mathrm{pH} 5,2$ y se incubó a $-20^{\circ} \mathrm{C}$ durante 15-30 min. Después se realizaron dos centrifugaciones seriadas a $14.000 \mathrm{rpm}$ durante $5 \mathrm{~min}$ y en cada una de ellas se lavó el pellet con alcohol al 70\%. El pellet se resuspendió en $500 \mu$ de buffer TE (Tris- $\mathrm{HCl} 10$ $\mathrm{mM}$; EDTA 0,1 mM, pH 8,0) y en un mismo volumen de polietilenglicol (PEG) al $13 \%$ en $\mathrm{NaCl} 1,6 \mathrm{M}$, luego se incubó en hielo durante $30 \mathrm{~min}$, se centrifugó a $14.000 \mathrm{rpm}$ durante $15 \mathrm{~min}$ y el pellet obtenido se lavó con etanol al $70 \%$. Se centrifugó nuevamente a $14.000 \mathrm{rpm}$ durante $5 \mathrm{~min}$, se secó y resuspendió en $20 \mu \mathrm{l}$ de TE. El ADN plasmídico así obtenido se conservó a -20 ํC hasta su posterior uso (Sambrook, 1989).

Cuando se necesitó ADN de pureza considerable, se extrajo y purificó el ADN plasmídico, con un kit comercial de Qiagen. El ADN plasmídico se cuantificó 
por espectrofotometría midiendo absorbancia a $260 \mathrm{~nm}$ o por medio del Qbit. Esta técnica tiene en cuenta que una unidad de DO. a $260 \mathrm{~nm}$ equivale a $50 \mu \mathrm{g}$ de ADN por ml. La pureza se determinó en base a la relación $\mathrm{DO}_{260 \mathrm{~nm}} / \mathrm{DO}_{280 \mathrm{~nm}}$. Se consideró un muy buen grado de pureza cuando esta relación fue superior a 1,8 .

\subsubsection{Secuenciación de ADN}

La secuenciación de ADN, se llevó a cabo en un servicio externo: Macrogen (Corea). Con el objetivo de controlar la presencia de las mutaciones de interés, se extrajo y purificó el ADN plasmídico utilizando el Kit de Qiagen, mediante el cual se obtiene ADN de pureza elevada. Se emplearon los oligonucleótidos universales S-tag y $\mathrm{T} 7$ terminator.

\section{Primers STag TM5: 5- CGAACGCCAGCACATGGACA-3 \\ Primers T7 terminator: 5- GCTAGTTATTGCTCAGCGG-3}

\subsubsection{Expresión de Proteínas recombinantes}

Se utilizó un sistema de expresión universal, bacterias E.coli cepa BL21, con vectores de expresión pET30. Las modificaciones genéticas que presenta esta cepa, como se mencionó anteriormente, la hace adecuada para la expresión de proteínas recombinantes. A nivel del vector de expresión, el inserto de cADN se encuentra bajo el control del promotor T7, que depende de la ARN polimerasa T7, cuyo gen se encuentra inserto en el ADN genómico de la bacteria. A su vez la ARN pol T7 se encuentra bajo el control del promotor lac, que puede ser inducido por IPTG. Una vez inducida la expresión del gen de interés, comienza la transcripción y traducción simultánea, la proteína recombinante producida, se acumula en su mayor parte en cuerpos de inclusión, que son agregados citoplasmáticos insolubles (Palmer y Wingfield, 2004). Estos se pueden aislar por centrifugación, y la recuperación de la proteína de interés suele requerir la desnaturalización con guanidina $\mathrm{HCl}$, seguido de diálisis a $\mathrm{pH}$ óptimo para el plegamiento (Thomas y Baneyx, 1996). Las bacterias BL21 competentes transformadas con el plásmido de interés, fueron sembradas en medio LB con kanamicina, se las incubó a $37^{\circ} \mathrm{C}$ toda la noche con agitación. Luego se tomó 1 
$\mathrm{ml}$ de medio de cultivo con las bacterias de interés, y se inoculó en $500 \mathrm{ml}$ de medio LB nuevo con kanamicina. Se las puso a crecer a $37^{\circ} \mathrm{C}$ en agitación hasta que la D. $O_{600 \mathrm{~nm}}$ llegará aproximadamente a 0,5. En ese momento se agregó IPTG 0,4 mM, y se incubó a 37\% durante por $2 \mathrm{~h}$. Después se centrifugó el medio de cultivo con las bacterias a $5.000 \mathrm{rpm}$ durante $5 \mathrm{~min}$. El sobrenadante fue descartado y el pellet se resuspendió en buffer fosfato con guanidina $\mathrm{HCl}$, se lo dejó en agitación al menos $4 \mathrm{~h}$. Por último se centrifugó el lisado celular a $10.000 \mathrm{rpm}$ y se retuvo el sobrenadante, que quedó listo para la purificación de las proteínas.

\subsubsection{Purificación de proteínas recombinantes}

La proteína recombinante presenta una cola de polihistidina, que posibilita su purificación mediante cromatografía de intercambio en metales inmovilizados (IMAC). Mediante esta técnica la cola de polihistidina, se adhiere a los metales, quedando la proteína retenida en la columna cromatográfica. Para su elusión se la somete a una solución con alto contenido de Imidazol, que compite con la cola de polihistidina, por la adhesión a los metales.

\subsubsection{Corte en medio ácido}

La proteína recombinante presenta un sitio de clivaje en medio ácido para la cola de polihistidina. Este sitio de clivaje fue insertado en el cADN de la apoA-I salvaje por el Dr. Prieto. La técnica consiste en cortar la cola de la proteína con ácido fórmico al $45 \%$, combinado con incubación a $60^{\circ} \mathrm{C}$ durante 5 o $6 \mathrm{~h}$. Luego se neutraliza con $\mathrm{NaOH}$ y se dializa durante toda la noche contra buffer fosfato, y se realizan tres cambios de buffer fosfato en el día. La muestra dializada que contiene la proteína cortada más la cola de polihistidina, se pasa nuevamente por la columna cromatográfica que retendrá a la cola poli-His libre así como restos de proteína no clivada. 


\subsection{TÉCNICAS ELECTROFORÉTICAS}

La electroforesis es un método mediante el cual se somete a las moléculas a un campo eléctrico y estas migran en base a su tamaño, forma, carga eléctrica y viscosidad del medio a través de un soporte, que puede ser de celulosa, agarosa, poliacrilamida entre otros. El soporte se comporta como un tamiz molecular, y permite separar moléculas cargadas en función de su tamaño y forma. El tamaño del poro del soporte se puede variar cambiando la concentración del polímero.

\subsubsection{Electroforesis en gel de Poliacrilamida (PAGE)}

El gel de poliacrilamida se forma por polimerización de la acrilamida, por acción de un agente entrecuzador, la bis-acrilamida, en presencia de un iniciador TEMED ( $N, N, N, N$ ' -tetrametilnediamina) y se utiliza como catalizador el ión persulfato $\left(\mathrm{S}_{2} \mathrm{O}_{8}{ }^{-}\right)$, que se añade en forma de persulfato de amonio. Estos geles son transparentes, estables, insolubles en agua, y permiten la visualización de las bandas. Las electroforesis PAGE las podemos clasificar, según el estado de las proteínas a lo largo de la corrida, en condiciones nativas 0 desnaturalizantes.

\subsubsection{Electroforesis PAGE en condiciones nativas}

\section{Geles en gradiente de $4-12 \%$}

Las proteínas migran en función de su carga, tamaño y forma. Un gel en gradiente se prepara siguiendo una concentración creciente de arcilamida y bisacrilamida, y como consecuencia un gradiente decreciente en el tamaño del poro. Las ventajas que encontramos frente a un gel de concentración uniforme es que la proteína migra hasta alcanzar una zona donde el tamaño del poro le impide seguir, de esta manera se resuelven mejor las bandas, ya que las concentra, y el rango de pesos moleculares que puede resolver es superior. El gel se tiñe con coomassie blue o con tinción de plata cuando las cantidades de proteínas son bajas. 


\subsubsection{Electroforesis PAGE en condiciones desnaturalizantes con SDS}

Las muestras se desnaturalizan por calor en presencia de agentes desnaturalizantes como $\beta$-mercaptoetanol y SDS (Laemmli, 1970). La estructura tridimensional de la proteína se pierde, y las cadenas polipeptídicas migran individualmente. EI SDS es un detergente iónico de acción desnaturalizarte que se une a las cadenas polipeptídicas desnaturalizadas. Ésta unión del SDS, bloquea la carga propia de la proteína y le confiere al complejo una carga neta negativa proporcional a su masa, haciendo que todas las proteínas unidas al SDS migren hacia el ánodo. Se prepararon geles de poliacrilamida con SDS a distinto porcentaje de acrilamida (12\% ○ 16\%) según las necesidades del estudio. Se tomaron $20 \mu \mathrm{l}$ de muestra más buffer muestra (4X) y se calentaron durante $3 \mathrm{~min}$. Luego se sembraron en el gel y se sometió a corrida electroforética a $120 \mathrm{~V}$ durante $1 \mathrm{~h}$. El gel se tiño con comassie blue y se decoloró con solución decolorante ácido acético:metanol:agua (1:4:5 v/v/v).

\subsubsection{Electroforesis en gel de agarosa}

La electroforesis en gel de agarosa es la más utilizada para analizar y caracterizar ácidos nucleicos. Permite separar fragmentos de ADN en base a su peso molecular. La presencia de ácidos nucleicos se detecta, mediante la utilización de colorantes fluorescentes como el bromuro de etidio o SYBR Green, que se intercalan entre las bases del ADN o ARN. Se preparó una solución de agarosa al $0,8 \% \mathrm{~m} / \mathrm{v}$ en buffer TBE. La agarosa se solubilizó mediante calentamiento, en microondas por pulsos de $20 \mathrm{~s}$. El contenido líquido se virtió en el soporte del gel horizontal y se colocó el peine adecuado a la cantidad de muestras. Se dejó gelificar y se sembraron $5 \mu \mathrm{l}$ de muestra con 1 $\mu \mathrm{l}$ de loading buffer más el estándar correspondiente. Se corrió a 100V en cuba electroforética horizontal, hasta que el frente de corrida recorrió el $80 \%$ de la longitud del gel. Para detectar la presencia de ácidos nucleicos se incubó el gel en bromuro de etidio $(0,5 \mu \mathrm{g} / \mathrm{ml})$ por $30 \mathrm{~min}$ o bien se agregó SYBR Green durante la solubilización de la agarosa. Las bandas de ADN se observaron a través de un transiluminador UV (Hoefer MacroVue UV-20). Los geles se fotografiaron utilizando una cámara de fotos digital KD120 (Kodak) y se analizaron con el software Kodak Digital Science 1D (Kodak). 
Soluciones

Buffer TBE: Tris 50 mM; Acido Bórico 50 mM; EDTA 1 mM

Loading Buffer: 6X NaOH 300 mM, 6 mM EDTA, 18\% p/v ficol, 0.15\% p/v verde de bromo cresol, y $0.25 \%$ p/v xileno cianol.

\subsection{PROTOCOLOS GENERALES DE TRABAJO CON ARN}

La extracción del ARN celular se efectuó a fin de poder realizar a posteriori una qRT-PCR con el objetivo de determinar la concentración de ARNm de ACAT-1. Las células RAW 264.7 fueron crecidas en placas de Petri hasta alcanzar confluencia celular. Luego se trató a las células con apoA-I y variantes de la misma: $\Delta \mathrm{K} 107$ y $\Delta \mathrm{K} 226$ a fin de determinar si se incrementaba la expresión del ARNm de ACAT-1.

\subsubsection{Extracción de ARN}

Durante todo el trabajo con ARN se utilizó agua libre de ARNasas con dietilpirocarbonato (DEPC) al 0,01\% v/v.

\subsubsection{Homogenización y precipitación del ARN}

Las monocapas celulares fueron lisadas y homogeneizadas con $1 \mathrm{ml}$ de Trizol (Invitrogen), que mantiene la integridad del ARN pero rompe y disuelve el resto de los componentes celulares (Chomczynski, 1987), luego el volumen se transfirió a tubos Eppendorf. Se incubaron las muestras durante $5 \mathrm{~min}$ a temperatura ambiente, para permitir la disociación de los complejos nucleoproteicos. Después se agregaron $200 \mu \mathrm{l}$ de cloroformo por $\mathrm{ml}$ de Trizol y se agitó vigorosamente por $15 \mathrm{~s}$ y se incubó nuevamente 5 min a temperatura ambiente. Con el fin de separar las fases se centrifugó a 12.000 rpm durante 15 min. Se obtuvo una fase orgánica, la de cloroformo que contenía restos celulares, una interfase donde se encontraba el ADN y la fase acuosa con el ARN. Se transfirió la fase acuosa a Eppendorf estériles, se agregó $500 \mu$ de alcohol isopropílico por $\mathrm{ml}$ de Trizol y se incubó por $10 \mathrm{~min}$ a temperatura ambiente. Finalmente se centrifugó a 12.000 rpm durante 10 min para precipitar al ARN. 


\subsubsection{Redisolución del ARN}

Se descartó el sobrenadante y se eliminaron los restos de contaminantes con etanol al 75\% con DEPC por $\mathrm{ml}$ de trizol. Luego se mezcló por agitación con vortex y se centrifugó durante $5 \mathrm{~min}$ a $7.500 \mathrm{rpm}$. Nuevamente se descaró el sobrenadante y se resuspendió el pellet en $50 \mu \mathrm{l}$ de agua con DEPC y luego se calentó durante 10 min a 55-60 ํ․ Finalmente el ARN se alicuotó y guardó a $700^{\circ}$. La extracción del ARN se controló mediante ge I de agarosa al 0,8\% con SYBR Green y se visualizó por transiluminador UV (Hoefer MacroVue UV-20). La concentración del ARN se determinó por Qbit utilizando los reactivos QuantiTTM ARN (Invitrogen).

\subsubsection{Cuantificación del ARNm ACAT-1 por qRT-PCR}

Con el fin de cuantificar el ARNm de ACAT-1 por qRT-PCR y como primer paso se sintetizó $C A D N$ a partir del ARN, obtenido de las células, usando la transcriptasa reversa.

\subsubsection{Síntesis de cADN}

A partir de $1 \mu \mathrm{g}$ de ARN total se sintetizó el cADN, empleando el kit cADN iScript synthesis (BioRad). La reacción de transcripción reversa se realizó siguiendo las instrucciones del fabricante y contenía: 3,4 $\mu \mathrm{ARN}, 4 \mu \mathrm{l}$ reaction $\operatorname{mix}(5 X), 2 \mu \mathrm{l}$ de random primers, 10,6 $\mu$ de agua libre de RNAsas, en un volumen total de $20 \mu \mathrm{l}$. La mezcla de reacción se incubó en un ciclador PCR Express (Thermo-Hybaid) a $25^{\circ} \mathrm{C}$ durante $5 \mathrm{~min}$, para que se unan los random primers al $A R N$, luego a $42^{\circ} \mathrm{C}$ durante $30 \mathrm{~min}$, para la síntesis del $\operatorname{cADN}, \mathrm{y}$ finalmente a $85^{\circ} \mathrm{C}$ por $5 \mathrm{~min}$, con el objetivo de inactivar la transcriptasa reversa.

\subsubsection{Amplificación}

Para la reacción de amplificación del cADN de ACAT-1 se utilizaron los siguientes primers:

Foward = 5' AGCAAGATGAAGCCCAGAAA 3'

Reverse = 5'ATGCGGACTTTTCAATGAGG 3' 
Se utilizó el Kit Brillant SYBR Green QPCR Mix (Stratagene) y se siguieron las instrucciones del fabricante. La reacción contenía un volumen final de $50 \mu \mathrm{l}, 2$ $\mu \mathrm{l} \mathrm{cADN}, 1 \mu \mathrm{l}(1 \mathrm{uM})$ Primers Foward, $1 \mu \mathrm{l}(1 \mu \mathrm{M})$ Primers Reverse, $1 \mu \mathrm{l}$ dNTPs, $5 \mu \mathrm{l}$ buffer Pfu (Stratagene) y $1 \mu \mathrm{l}$ Pfu polimerasa (Stratagene) y $39 \mu \mathrm{l}$ de agua con DEPC. Como control positivo de expresión se utilizó $\beta$ - actina.

\subsubsection{1 qRT-PCR Ciclos de temperatura}

A continuación en la tabla 3-3 se muestran los ciclos de temperatura que fueron utilizados para la qRT-PCR.

Tabla 3-3. Ciclos de temperatura qRT-PCR, para la cuantificación del ARNm de ACAT-1.

\begin{tabular}{|c|c|c|c|}
\hline Segmento & Ciclos & Temperatura & Tiempo \\
\hline \multirow[t]{2}{*}{1} & 1 & $50^{\circ} \mathrm{C}$ & $10 \min$ \\
\hline & & $95^{\circ} \mathrm{C}$ & $5 \mathrm{~min}$ \\
\hline \multirow[t]{3}{*}{2} & 40 & $95^{\circ} \mathrm{C}$ & $30 \mathrm{~s}$ \\
\hline & & $60^{\circ} \mathrm{C}$ & $1 \mathrm{~min}$ \\
\hline & & $72^{\circ} \mathrm{C}$ & $30 \mathrm{~s}$ \\
\hline
\end{tabular}

\subsection{PROTOCOLOS GENERALES DE TRABAJO CON PROTEÍNAS}

\subsubsection{Determinación de la concentración proteica}

La apoA-I como las variantes de la misma, fueron cuantificadas por espectrofotometría a $280 \mathrm{~nm}$, analizando el espectro de absorbancia en el UV 200-400 nm. A partir de este espectro y conociendo los coeficientes de extinción de la apoA-I y variantes, se pudo determinar la concentración proteica. Para la determinación de proteínas totales se utilizó un método colorimétrico, el método de Lowry (1951). Para cada determinación proteica se realizó una curva de calibración, a partir de una solución patrón de $2 \mathrm{mg} / \mathrm{ml}$ de albúmina de suero bovino (BSA). 


\subsubsection{Identificación de ACAT-1 por western blot}

El tratamiento utilizado sobre las células RAW 264.7, fue el mismo aplicado en la remoción de colesterol que se describe en la sección 3.10.1. Las células RAW 264.7 fueron tratadas con apoA-I y sus variantes: $\Delta \mathrm{K} 107$ y $\Delta \mathrm{K} 226$, sólo que en este caso las monocapas celulares se destinaron al análisis proteico.

\subsubsection{Separación y Transferencia de proteínas}

Las monocapas celulares fueron raspadas y tratadas con buffer muestra para su separación proteica en gel de poliacrilamida con SDS (Laemmli, 1970). Las proteínas separadas por SDS-PAGE fueron transferidas a membranas de nitrocelulosa. Antes de la transferencia, la membrana, el gel y los papeles de filtro se humedecieron en buffer de transferencia durante $10 \mathrm{~min}$. La transferencia se realizó a 100V durante $1 \mathrm{~h}$.

\subsubsection{Incubación con anticuerpo}

Después de la transferencia la membrana se bloqueó durante $1 \mathrm{~h}$ o toda la noche a $4^{\circ} \mathrm{C}$ con solución de bloqueo. Seguidamente se incubó con el anticuerpo primario, anti-ACAT-1 (Santa Cruz), con una dilución de 1/200 en buffer de bloqueo, durante $1 \mathrm{~h}$. a temperatura ambiente con agitación suave. Después se lavó la membrana con buffer Tris-Salino y se incubó con el anticuerpo secundario (anti-lgG rabbit), con una dilución de 1/1000 en buffer de bloqueo durante $2 \mathrm{~h}$ a temperatura ambiente con agitación suave. Para finalizar la membrana se reveló por electroquimioluminiscencia (ECL) y de esta manera se determinó la presencia de la proteína. La cuantificación se llevó a cabo por medio del programa ImageJ en relación a la $\beta$ - actina usada como control.

\subsection{PROTOCOLOS GENERALES DE TRABAJO CON CÉLULAS}

Se trabajó con dos líneas celulares diferentes, células derivadas de ovario de hámster chino ( $\mathrm{CHO}-\mathrm{K} 1$ ), y macrófagos murinos (RAW 264.7). A medida que se avanzó en el trabajo de tesis se decidió continuar trabajando sólo con los macrófagos, ya que eran más adecuados para el trabajo planteado, por su intervención en la formación de la placa ateromatosa. 


\subsubsection{Mantenimiento de células en cultivo}

\subsubsection{Células CHO-K1}

Las células $\mathrm{CHO}-\mathrm{K} 1$ son una línea celular derivada como subclon, de la línea parental $\mathrm{CHO}$, iniciada a partir de una biopsia de ovario de hámster chino (Puck, 1957). La morfología de estas células es de tipo epitelial. Las células fueron crecidas en medio esencial mínimo (MEM de GIBCO), suplementado con $10 \%$ de suero fetal bovino (SFB de Bioser) y $1 \%$ antibiótico/antimicótico (100 U/ml penicilina G sódica; $100 \mu \mathrm{g} / \mathrm{ml}$ streptomicina sulfato) a $37^{\circ} \mathrm{C}$ en estufa gaseada con $5 \%$ de $\mathrm{CO}_{2}$. Las células $\mathrm{CHO}-\mathrm{K} 1$ tienen una elevada tasa de crecimiento celular, por lo que el medio se renovó cada $48 \mathrm{~h}$.

\subsubsection{Células RAW 264.7}

Las células RAW 264.7, macrófagos murinos, son una línea celular establecida a partir de un tumor inducido por el virus Abelson, de la leucemia murina. Las células fueron cultivadas en medio esencial mínimo modificado (DMEM de GIBCO), suplementado con $10 \%$ de SFB, usando la misma mezcla de antibiótico/antimicótico y condiciones de incubación empleadas con células CHO-K1. Las células RAW 264.7 también presentan una alta tasa de crecimiento por lo que el medio se cambió al igual que en células $\mathrm{CHO}-\mathrm{K} 1$ cada $48 \mathrm{~h}$.

\subsubsection{Subcultivo de células}

Cuando las células alcanzan alrededor del $80 \%$ de confluencia se realiza el subcultivo o repique de las mismas, que consiste en efectuar un tratamiento enzimático con el fin de romper las uniones entre células y aquellas entre células y la superficie de crecimiento. Este tratamiento se hace con una combinación de tripsina y EDTA. Luego se recolectan las células, se realiza un ensayo de viabilidad celular con tripan blue (sección 3.8.2.1), y se siembran nuevamente en una placa estéril dentro del flujo laminar. Se lavaron las monocapas celulares con buffer PBS (NaCl 8 g/l; KCl 0,2 g/l; $\mathrm{Na}_{2} \mathrm{HPO}_{4}$ 1,44 g/l; $\mathrm{KH}_{2} \mathrm{PO}_{4}$ 0,24 $\mathrm{g} / \mathrm{l}$ ) estéril. Luego se agregó a cada placa $1 \mathrm{ml}$ de tripsina (PAA 
Switzerland) (tripsina 0,05\% - EDTA 0,02\% en PBS) a cada placa, y se incubó a $37^{\circ} \mathrm{C}$ durante 2 min para acelerar el proceso. Se observó el estado de la monocapa mediante microscopio óptico invertido y se neutralizó la tripsina con $7 \mathrm{ml}$ de medio de cultivo con $10 \%$ SFB. Se homogeneizaron las células y se transfirió una alícuota en una relación 1/10, a una nueva placa estéril con medio de cultivo fresco.

\subsubsection{Criopreservación de células en nitrógeno líquido}

Con el objetivo de conservar líneas celulares por largos períodos de tiempo, se las almacenó en nitrógeno líquido. Las monocapas fueron lavadas con PBS y se desprendieron las células con tripsina. Luego se neutralizó con medio de cultivo con $10 \%$ de SFB. La solución celular fue homogeneizada, y se transfirió el volumen a tubos Falcón estériles. Se centrifugó por 10 min a 2.000 rpm, se descartó el sobrenadante y el precipitado celular se lavó con PBS estéril. EI pellet celular se resuspendió en solución de congelación (90\% SFB y 10\% DMSO) (Helgason, 2005) y se transfirió casi todo el volumen a criotubos (GIBCO) de $2 \mathrm{ml}$. Se tomó una alícuota para realizar el test de viabilidad celular con trypan blue, previo al congelamiento (sección 3.8.2.1). Finalmente los criotubos se enfriaron por $24 \mathrm{~h} \mathrm{a}-20^{\circ} \mathrm{C}$ y luego fue ron transferidos al tanque de nitrógeno líquido, para su conservación.

\subsubsection{Detección de contaminantes: Micoplasmas}

Se realizaron controles de rutina, en colaboración con el Dpto. de Patología (Facultad de Ciencias Médicas, UNLP) para la detección de Micoplasmas. El ensayo consitó en teñir las monocapas celulares con el reactivo de Hoesch (fluorocromo que se une al ADN), y posteriormente observar mediante microscopio de fluorescencia, la presencia o ausencia de micoplasmas. Se sembraron células sobre cubre objetos estériles dentro de una placa de Petri y se los dejo crecer durante $24 \mathrm{~h}$. Luego se agregó solución de fijación (metanol:ácido acético 3:1 v/v) sin remover el medio y se lo dejó reposar 2 min. Seguidamente se retiró el medio de cultivo y se agregó nuevamente solución de fijación y se dejó reposar 5-10 min. Después se removió la solución de 
fijación y se dejo secar. Finalmente se agregó $0,05 \mu \mathrm{g} / \mathrm{ml}$ de reactivo de Hoesch y se incubó por 10 min a temperatura ambiente. Las monocapas fueron lavadas varias veces con agua destilada. Se adicionó solución de montaje y se observó al microscopio de fluorescencia.

\subsubsection{Ensayos de viabilidad celular}

\subsubsection{Método de exclusión con Trypan Blue}

Este método se basa en la captación del azul tripan por células no viables, las cuales se observarán de color azul y las células viables, que no lo captan, se verán refringentes. El recuento de células se realiza en cámara de Neubauer y se determina el \% de células vivas sobre el total de células. Se tomó una alícuota de suspensión celular de $90 \mu \mathrm{l}$ y se agregó $30 \mu \mathrm{l}$ de azul tripan al 0,2\% en buffer PBS, se dejó reposar 1 min y se realizó el recuento en cámara de Neubauer.

\subsubsection{Test MTT}

El ensayo del MTT (bromuro de 3-(4,5-dimetil-2-tiazolil)-2,5-difenil-2Htetrazolio) es usado ampliamente para evaluar la citotoxicidad de distintas moléculas y drogas en cultivos celulares. Las células metabólicamente activas pueden endocitar al MTT, y reducirlo a nivel mitocondrial en formazán, insoluble y de color púrpura. La salida del MTT formazán de la célula se revela por la presencia de cristales de formazán en la superficie de la membrana celular.

\subsection{Efecto citotóxico del colesterol}

Con el fin de determinar si ciertas concentraciones de colesterol eran tóxicas para las células, se decidió realizar el test de MTT. Se sembraron 2,5 × $10^{5}$ células RAW 264.7 en placas de 24 pocillos, se dejó crecer hasta confluencia. Luego las células fueron incubadas por $24 \mathrm{~h}$ con diferentes concentraciones de colesterol en medio DMEN sin SFB, en una atmósfera humidificada con $5 \%$ $\mathrm{CO}_{2}$ y un $95 \% \mathrm{O}_{2}$ a $37^{\circ} \mathrm{C}$. Después del tratamiento de $24 \mathrm{~h}$, el medio fue 
sustraído y se adicionó el MTT, a una concentración final de $0,5 \mathrm{mg} / \mathrm{ml}$, durante $3 \mathrm{~h}$ a $37^{\circ} \mathrm{C}$. EI MTT fue retirado y cada pocillo se I avó con PBS y se adicionó dimetil sulfóxido (DMSO) para solubilizar los cristales de MTT formazán. La absorbancia fue medida a una longitud de onda de $560 \mathrm{~nm}$ con la substracción del background a $640 \mathrm{~nm}$. Para la medición se utilizó el DTX 880 multilector Beckman-Coulter.

\subsection{Efecto citoprotector apoA-I y variantes}

En una placa de 96 pocillos se sembraron $7 \times 10^{4}$ células RAW 264.7 resuspendidas en $100 \mu \mathrm{l}$ de DMEM con $10 \%$ de SFB y se las incubó hasta alcanzar confluencia. Luego de la incubación se retiró el medio de cultivo por inversión sobre papel y se agregó medio de cultivo sin SFB, con 0,5 mM de 8bromoadenosina-3,5-monofosfato cíclico (Br-AMPc) y $2 \mathrm{mg} / \mathrm{ml}$ albúmina sérica libre de ácidos grasos, y concentraciones variables de colesterol (entre 0 y 500 $\mu \mathrm{g} / \mathrm{ml}$ ), en ausencia o presencia de $30 \mu \mathrm{g} / \mathrm{ml}$ de apoA-I sérica (apoA-ls), apoA-I recombinante (apoA-Ir) y mutantes de apoA-I: $\Delta \mathrm{K} 107$ y $\Delta \mathrm{K} 226$. Después de 24 $h$ de tratamiento se eliminó el medio de cultivo y se adicionó el MTT a una concentración final de $0,5 \mathrm{mg} / \mathrm{ml}$ y se incubó durante $3 \mathrm{~h}$. Finalizada la incubación se retiró el MTT y se lavó con $100 \mu \mathrm{l}$ de PBS. Seguidamente se agregaron $100 \mu \mathrm{l}$ de DMSO (solvente orgánico), para solubilizar el formazán. Se dejó actuar durante 10 min a temperatura ambiente con agitación y se realizaron las mediciones de absorbancia como se explicó arriba (sección 3.8.2.2.1).

\subsection{PARTÍCULAS rHDL}

\subsubsection{Reconstitución de partículas discoidales: rHDL}

Con el fin de obtener partículas discoidales, parecidas a las pre- $\beta$ HDL del plasma, que se encuentran en muy baja concentración, se reconstituyeron dHDL por el método de diálisis con colato (Matz y Jonas, 1982; Jonas, 1986; Durbin y Jonas, 1997). A partir de POPC (1-palmitoil-2-oleoilfosfatidilcolina), apoA-I y colato, se realizó la reconstitución de $\mathrm{dHDL}$ de diferente tamaño y composición de colesterol. La relación molar utilizada fue la siguiente: 95/1/150 
y 40/1/65 de POPC/apoA-l/colato de sodio para las partículas de $96 \AA$ y $78 \AA$ respectivamente. Las partículas de $120 \AA$ se obtuvieron de la mezcla de reconstitución de las rHDL de $96 \AA$ A. En el caso de las dHDL conteniendo colesterol, éste se adicionó en una relación molar de 4:1 (POPC:col.). Se utilizaron soluciones madre de POPC y colesterol en cloroformo. Éstas fueron evaporadas con $\mathrm{N}_{2}$, hasta eliminar el solvente. Luego se agregaron $500 \mu \mathrm{l}$ de buffer TBS (Tris $10 \mathrm{mM}, \mathrm{CINa} 150 \mathrm{mM}$ ) a un pH 8,0, con el fin de humectar la muestra y se dejó reposar durante 5 min en hielo, seguido de agitación con vortex. Se añadió el colato y se dejó reposar durante $60 \mathrm{~min}$ en hielo. Después se agregó la apoA-I bajo $\mathrm{N}_{2}$, y se mezcló por rotación, incubándola durante 30 a $60 \mathrm{~min}$ en hielo. Luego la muestra fue dializada contra buffer TBS con el fin de remover el colato, realizándose al menos tres cambios de buffer en el día. Después de dializar, las muestras fueron purificadas mediante cromatografía de exclusión molecular, usando dos columnas en tándem (Superosa $6+$ Superdex 200 de Pharmacia). El control de pureza de las dHDL se realizó por medio de electroforesis en gel de poliacrialamida en gradiente $8-25 \%$, en condiciones no desnaturalizantes. Para determinar el peso molecular se utilizaron estándares comerciales (Pharmacia). La concentración de las partículas reconstituidas fue determinada por absorbancia a $280 \mathrm{~nm}$, usando el coeficiente de extinción molar de la apoA-I.

\subsubsection{Afinidad de rHDL por membranas}

\subsubsection{ELISA sobre células}

El ensayo de ELISA sobre células, permite la detección de antígenos de superficie celular, y se basa en la especificidad antígeno- anticuerpo. En este caso uno de los reactantes, el antígeno ( $\mathrm{Ag})$, se encuentra inmovilizado en la fase sólida y el reactante soluble, el anticuerpo (Ac), se une específicamente a éste. Este tipo de ELISA se denomina heterogéneo y consta de tres etapas: la inmovilización del reactante en la fase sólida; la incubación de la muestra, de modo que ésta reaccione con el reactante inmovilizado, y por último la amplificación de la señal, por medio de un conjugado enzimático, que al reaccionar con el sustrato, OPD (O-fenilendiamina dihidroclorhídrico) o ABTS 
(ácido 2,2'-azino-bis-3-etilbenzotiazolina-6-sulfónico) desarrolla color, el cual se mide espectrofotométricamente. Se sembraron aproximadamente $7 \times 10^{4}$ y 2 x10 ${ }^{5}$ células RAW 264.7 en placas de 96 y 24 pocillos respectivamente, con medio DMEM conteniendo SFB y se las dejó crecer durante $24 \mathrm{~h}$. Las células fueron activadas con 2,5 $\mu \mathrm{g} / \mathrm{ml}$ 22-R-hidroxicolesterol (H-Col) y $0,75 \mu \mathrm{g} / \mathrm{ml}$ 9cis-ácido retinoico (AR) o con 0,5 mM de Br-AMPc durante $24 \mathrm{~h}$ en medio sin SFB. Después se agregaron las partículas rHDL a una concentración de 48 $\mu \mathrm{g} / \mathrm{ml}$ en DMEM sin SFB, y fueron incubadas durante $1 \mathrm{~h}$ a 37 o $4 \stackrel{\circ}{\circ} \mathrm{C}$. Luego los pocillos se lavaron con PBS y se agregó la solución de bloqueo (buffer PBS con $1 \%$ albúmina sérica) durante $1 \mathrm{~h}$. El anticuerpo policlonal anti-apoA-I fue agregado en una dilución de 1:1000 y se incubó por 1 h. Entre incubación de anticuerpo y anticuerpo, se lavó sucesivamente con PBS. El anticuerpo secundario anti-rabbit IgG asociado a peroxidasa, fue incubado a una dilución de 1:1500 durante $1 \mathrm{~h}$. Por último se lavó con PBS y se agregó el sustrato ABTS u OPD, con el fin de realizar la lectura espectrofotométrica, en DTX 880 multilector Beckman-Coulter. En el caso de usarse OPD, la reacción se frenó con $\mathrm{H}_{2} \mathrm{SO}_{4} 4 \mathrm{~N}$.y la lectura se hizo a $492 \mathrm{~nm}$, en cambio cuando se utilizó como sustrato el ABTS, la lectura se hizo a 405 nm (Crowther, 2009; Price, 1990).

\subsection{ENSAYOS DE REMOCIÓN DE LÍPIDOS}

\subsubsection{Ensayo de Remoción de Colesterol}

Con el fin de determinar el comportamiento de las partículas rHDL y variantes de apoA-I sobre el metabolismo del colesterol, se realizó el siguiente experimento: las células RAW 264.7 fueron cultivadas en placas de 6 pocillos, con medio de cultivo DMEM con $10 \%$ SFB, hasta alcanzar una confluencia del $80-90 \%$. Se sembraron aproximadamente entre $2 \times 10^{5}$ y $3 \times 10^{5}$ células RAW 264.7. Una vez alcanza la confluencia esperada, las monocapas se lavaron con buffer salino (PBS) y se añadió una solución de carga que contenía: $50 \mu \mathrm{g} / \mathrm{ml}$ de colesterol, y $0,05 \mu \mathrm{Ci} / \mathrm{ml}$ de $\left[{ }^{14} \mathrm{C}\right]$ colesterol, en medio sin SFB complementado con $2 \mathrm{mg} / \mathrm{ml}$ de albúmina de suero bovina (BSA) libre de ácidos grasos, se incubó durante $24 \mathrm{~h}$ a $37^{\circ} \mathrm{C}$. Termi nada la incubación se lavaron las monocapas nuevamente con PBS y se adicionó una solución para 
equilibrar los pooles de colesterol intracelulares. Esta solución de equilibrado estaba compuesta por medio de cultivo $\sin \mathrm{SFB}, 1 \mathrm{mg} / \mathrm{ml}$ de albúmina sérica libre de ácidos grasos, y en el caso de las células RAW 264.7, que necesitan activación, se añadió $0,5 \mathrm{mM}$ de Br-AMPc y se las incubó durante $8 \mathrm{~h}$ a $37^{\circ} \mathrm{C}$. Finalizado el equilibrado se lavaron las monocapas con PBS, y se adicionaron las HDL reconstituídas o las variantes de apoA-I, en medio de cultivo sin SFB. En el caso de las RAW 264.7, se las activó nuevamente con 0,5 mM de BrAMPc y se las incubó durante $12 \mathrm{~h}$. Luego el medio fue colectado y las monocapas se trataron separadamente. La radioactividad se determinó mediante contador de centelleo líquido y el porcentaje de eflujo de colesterol se calculó como el porcentaje relativo de radioactividad en el medio en relación al total de radiactividad detectado en las células y en el medio. La extracción lipídica se realizó mediante el método Bligh \& Dyer (sección 3.11.1) y las fracciones lipídicas fueron separadas por cromatografía en capa fina (TLC) (sección 3.11.2).

\subsubsection{Ensayo de Remoción de Fosfolípidos}

El procedimiento llevado a cabo fue similar a la remoción de colesterol (sección 3.10.1); sólo que la carga se realizó con $0,5 \mu \mathrm{ci} / \mathrm{ml}$ de $\left[{ }^{14} \mathrm{C}\right]$ fosforilcolina o $\left[{ }^{14} \mathrm{C}\right]$ colina. El tratamiento con las partículas $\mathrm{rHDL}$ o variantes de apoA-I fue realizado a $12 \mathrm{~h}$ y el porcentaje de eflujo de fosfolípidos se determinó de la misma manera que para la remoción de colesterol (sección 3.10.1).

\subsection{ANÁLISIS DE LÍPIDOS}

\subsubsection{Extracción de lípidos}

Con el fin de determinar el porcentaje de eflujo de lípidos y analizar la composición lipídica, primeramente se extrajeron los lípidos de las monocapas celulares mediante la técnica de Bligh \& Dyer (Bligh y Dyer, 1959). Las monocapas celulares fueron lavadas con PBS y luego resuspendidas en una mezcla de metanol:cloroformo:agua $(2: 1: 0,5 \mathrm{v} / \mathrm{v} / \mathrm{v})$ y transferidas a un tubo cónico. Luego se centrifugó por $5 \mathrm{~min}$ para precipitar restos celulares y se transfirió el sobrenadante a un tubo limpio. Ambos tubos se trataron 
nuevamente con Bligh \& Dyer, seguido de centrifugación por 5 min y se recolectó el sobrenadante. Se agregó $1 \mathrm{ml}$ de agua y $1 \mathrm{ml}$ de cloroformo para particionar y se centrifugó durante $5 \mathrm{~min}$. Se descartó la fase superior (acuosa) y se retuvo la fase inferior (orgánica). Luego se evaporó el solvente y se resuspendió en $500 \mu \mathrm{l}$ de Bligh \& Dyer (metanol:cloroformo 2:1 v/v). Se tomó una alícuota para determinar la radioactividad en el contador de centelleo líquido y el resto se utilizó para determinar las especies lipídicas.

\subsubsection{Cromatografía en capa fina (TLC)}

Luego de la extracción lipídica, parte del extracto se utilizó para determinar los lípidos presentes. Se realizó una TLC, para separar las distintas fracciones de lípidos polares y otra, para los no polares. Para ello se utilizaron placas de silica gel G-60 (Merck, Germany) como fase estacionaria y una mezcla de solventes como fase móvil. En el caso de los lípidos polares la mezcla de solventes utilizada fue: cloroformo:metanol:ácido acético:agua 50:37,5:3,5:2 v/v/v/v, y se usaron estándares de fosfatidilcolina (PC) y esfingomielina (SM). En el caso de los lípidos no polares, la mezcla de solventes utilizada fue: hexano:éter etílico:ácido acético 40:10:0,5 v/v/v, y se usaron como estándar colesterol (col.) y ésteres de colesterol (CE). Los solventes utilizados fueron todos de calidad analítica. Las placas se revelaron rutinariamente con $\mathrm{l}_{2}$, salvo cuando se necesitó determinar la relación de radioactividad entre especies lipídicas se utilizó software Imagen Quant del Storm.

\subsection{ANÁLISIS ESTADÍSTICOS DE RESULTADOS}

Los análisis estadísticos se realizaron mediante test $t$ de Student o ANOVA, según el diseño experimental, seguido de test de TUKEY. Los datos cumplieron los supuestos de ANOVA, homogeneidad de varianza (test de Levene's) y normalidad (test de Kolmogorov-Smirnov). Los resultados se expresaron como la media \pm SE de tres experimentos independientes. 


\section{CAPÍTULO 4.}

\section{COMPORTAMIENTO DE LAS dHDL DE}

DIFERENTE TAMAÑO Y COMPOSICIÓN EN EL

EFLUJO LIPÍDICO CELULAR 


\section{CAPÍTULO 4. COMPORTAMIENTO DE LAS AHDL DE DIFERENTE TAMAÑO Y COMPOSICIÓN EN EL EFLUJO LIPÍDICO CELULAR}

\subsection{ANTECEDENTES}

\subsubsection{Visión actual del TRC. Rol de las dHDL}

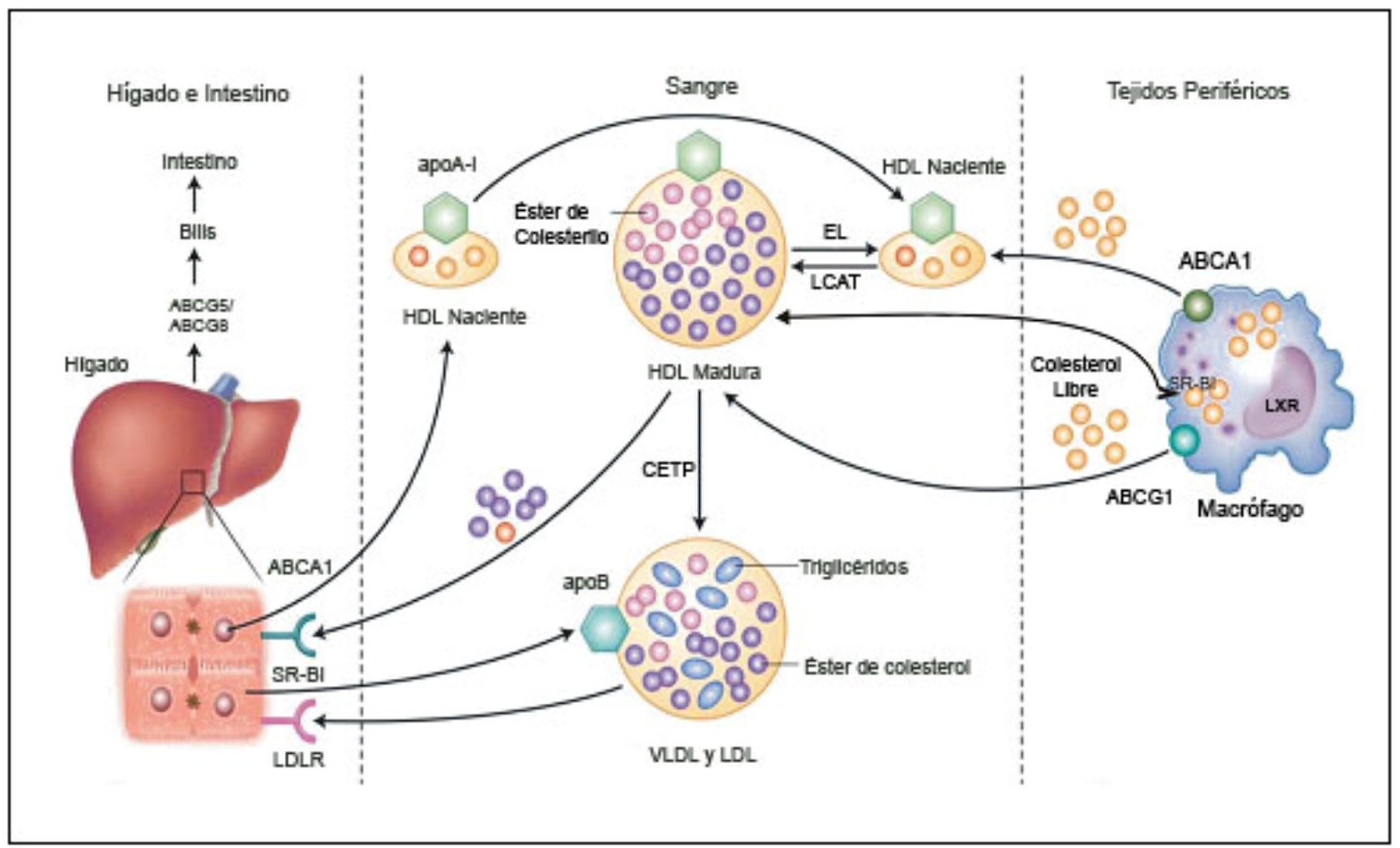

Figura 4-1. Diagrama de los principales eventos del TRC (Khera y Rader, 2010 con modificaciones). Luego de ser secretada por el hígado, apoA-I adquiere fosfolípidos (PL) y algo de colesterol no esterificado (FC) del mismo hígado o de células periféricas incluidos los macrófagos, por la actividad de ABCA1 generándose dHDL nacientes. Parte de apoA-I no lipidada es eliminada por riñón. Los ésteres de colesterol (CE) intracelulares son hidrolizados y el FC resultante es movilizado a la membrana celular. Las proteínas ABCG1 y SR-BI promueven la salida de FC a HDL preformadas pero no a apoA-I libre. Por acción de LCAT, las dHDL son convertidas en HDL esféricas con un núcleo de CE. La proteína transferidora de fosfolípidos (PLTP) provee fosfatidilcolina (PC) para la reacción de LCAT transfiriéndolos desde LDL o VLDL. A través de la proteína transferidora de ésteres de colesterol (CETP), y en intercambio por triacilgliceroles (TG), los CE de HDL son transferidos a VLDL o LDL, las que son captadas en hígado vía el receptor de LDL (LDLR). En el hepatocito, SR-BI media la captación selectiva de CE y FC de las HDL. Este proceso, además de las actividades de lipasa hepática (HL) y lipasa endotelial (EL), liberan apoA-I que queda disponible para reiniciar la captación de lípidos celulares mediada por ABCA1. El colesterol captado por hígado es excretado en bilis como FC o sales biliares vía transportadores ABCG5 y ABCG8, pero en parte puede ser reciclado en el TRC vía ABCA1, o ser ensamblado en VLDL y resecretado a la circulación. 
La figura 4.1 resume los principales eventos del TRC. Tanto apoA-I libre (o pobre en lípidos) como las $\mathrm{dHDL}$ son intermediarios claves en este proceso. Las dHDL son inicialmente generadas por la acción del ABCA1, mientras que ABCG1 y SR-BI contribuyen a su posterior enriquecimiento en colesterol. Ya en circulación, las dHDL son sustrato de LCAT y precursoras de las HDL esféricas mayoritarias en circulación, cuya remodelación por diferentes mecanismos conduce a la regeneración de apoA-I libre o pobre en lípidos que reinicia el ciclo.

La captación de lípidos celulares por apoA-I y dHDL es muy dependiente del tipo celular así como su estado metabólico, carga de colesterol y nivel de expresión de transportadores y receptores celulares. En células RAW 264.7 y CHO-K1, el nivel de expresión basal del ABCA1, ABCG1 y SR-BI es bajo (Favari y col., 2009). La expresión de ABCA1 y ABCG1 puede ser estimulada con $\mathrm{H}-\mathrm{Col}$ y $\mathrm{AR}$ o cargando las células con colesterol, pero ocurre lo opuesto con el SR-BI (Lorenzi y col., 2008; Ji y col., 2011; Yu y col., 2004). En la actualidad estos mecanismos moleculares son pobremente conocidos y seguramente a medida que pase el tiempo y se enriquezca el conocimiento se encontraran más transportadores y diferentes mecanismos involucrados en el transporte reverso de colesterol mediado por las HDL.

\subsubsection{Propiedades y funcionalidad de las $\mathrm{dHDL}$}

Distintas evidencias indican que las propiedades y el comportamiento de las dHDL en las distintas etapas del TRC podría depender de su tamaño, composición, número y conformación de apoA-I en las partículas. Debido a su heterogeneidad y baja concentración, las dHDL son difíciles de obtener a partir del plasma humano. Por tanto, la mayoría del conocimiento actual sobre las propiedades y funcionalidad de las dHDL proviene de estudios con dHDL reconstituidas ( $\mathrm{rHDL}$ ) por distintos métodos como la diálisis de micelas mixtas con el detergente colato.

Diferentes estudios indicaron que la capacidad para interactuar e intercambiar colesterol con membranas artificiales disminuye al incrementar el tamaño y 
contenido de colesterol de las rHDL (Tricerri y col., 1998; Toledo y col., 2000). Esto fue atribuido a cambios conformacionales que resultan en un menor grado de exposición de un dominio central de la molécula de apoA-I (Tricerri y col., 1998).

Estos cambios conformacionales también podrían resultar en una diferente afinidad por transportadores y receptores celulares determinando una diferente capacidad para movilizar lípidos celulares. Tanto el contenido lipídico como la cantidad de apoA-I por disco, son determinantes de la conformación de apoA-I en los complejos lipoproteicos (Cavigiolio y col., 2008). Recientemente se ha reportado (Favari y col., 2009) que las rHDL de $78 \AA$ promueven el eflujo de colesterol celular vía $A B C A 1$ y ABCG1 pero no vía SR-BI. Aquellas $\mathrm{rHDL}$ de tamaño $\geq 96 \AA$ y las HDL esféricas, en cambio, promueven la remoción del colesterol celular a través de ABCG1 y SR-BI, pero no vía ABCA1 (Favari y col., 2009; Lorenzi y col., 2008).

Se ha postulado que esta variabilidad o flexibilidad conformacional también afecta la afinidad por enzimas como LCAT. Las rHDL $78 \AA$ presenta una menor habilidad para activar LCAT en comparación con las rHDL de $96 \AA$ (Tricerri y col., 2002). Según Cavigiolio y col. (2008), las rHDL de $96 \AA$ son buenos sustratos de LCAT, pero las rHDL que contienen más de dos moléculas por partícula como las rHDL de 134 y 170 Å son aún mejores sustratos de LCAT.

\subsection{OBJETIVOS PARTICULARES}

Para tratar de reconstruir in vitro lo que ocurre a nivel del inicio del TRC, se reconstituyeron partículas $\mathrm{rHDL}$ de distinto tamaño y composición (de 78, 96 y $120 \AA$ sin y con colesterol) con el objetivo de evaluar su comportamiento a nivel del eflujo de colesterol y fosfolípidos, como así también su capacidad para unirse a la membrana celular en dos tipos celulares diferentes: macrófagos murinos, RAW 264.7 y células de tipo epitelial, CHO-K1.

La elección de estas dos líneas celulares radica en que los macrófagos (RAW 264.7) intervienen en la formación de las placas ateromatosas, acumulan 
ésteres de colesterol y se convierten en células espumosas, siendo uno de los partícipes más importantes de la formación de la placa ateromatosa. En cambio las células $\mathrm{CHO}-\mathrm{K} 1$ se utilizaron como modelo de otro tipo de célula periférica, que no interviene en la formación de la placa ateromatosa. Es sabido que la mayor parte de colesterol removido en el transporte reverso proviene principalmente de células periféricas, de ahí radica la importancia de estudiar la capacidad de unión a membranas y el eflujo lipídico con ambas líneas celulares.

\subsection{RESULTADOS}

\subsubsection{Comportamiento de las dHDL en células CHO-K1}

\subsubsection{Capacidad de unión a membrana}

Por medio del ensayo de ELISA que permite la detección de antígenos de superficie celular en base a la afinidad antígeno- anticuerpo, se determinó la unión a membranas de apoA-I y partículas rHDL de distinto tamaño y composición: 78, 96 y $120 \AA$ con y sin colesterol en células CHO-K1, con el fin de obtener mayor información con respecto al comportamiento de las dHDL en el TRC en diferentes tipos celulares. Las monocapas celulares fueron crecidas hasta alcanzar una confluencia del $80-90 \%$, luego se realizó el ensayo de ELISA sobre células. Las células fueron estimuladas con hidroxicolesterol $(\mathrm{H}-$ Col) y acido retinoico (AR) durante $24 \mathrm{~h}$ a $37^{\circ} \mathrm{C}$ con el fin de incrementar la expresión de los transportadores $A B C$ (ABCA1 y ABCG1) que intervienen en el eflujo de lípidos. Seguidamente las células fueron incubadas con $48 \mu \mathrm{g} / \mathrm{ml}$ apoA-I y rHDL de distinto tamaño y composición: 78, 96 y $120 \AA$ con y $\sin$ colesterol durante $1 \mathrm{~h}$ a $37^{\circ} \mathrm{C}$. 


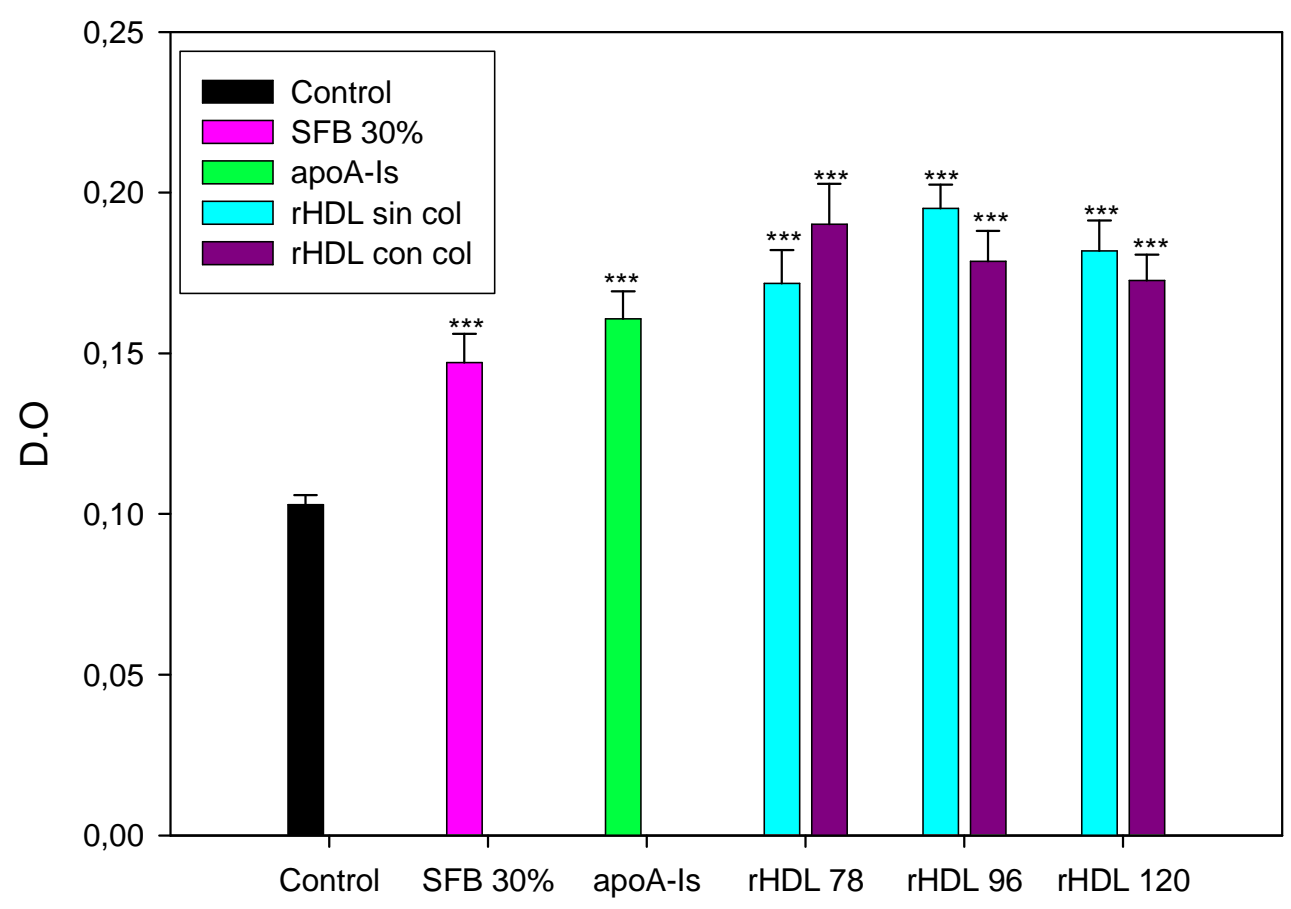

Figura 4-2. Capacidad de unión a membranas en células $\mathrm{CHO}-\mathrm{K} 1$. Las células fueron activadas con 2,5 $\mu \mathrm{g} / \mathrm{ml} \mathrm{H}$-Col y $0,75 \mu \mathrm{g} / \mathrm{ml}$ AR durante $24 \mathrm{~h}$ en medio MEM sin suero fetal bovino (SFB) a $37^{\circ} \mathrm{C}$ e incubadas con $48 \mu \mathrm{g} / \mathrm{ml}$ de apoA-I y rHDL 78, 96 y $120 \AA$ con y sin colesterol durante $1 \mathrm{~h}$. a la misma temperatura, antes de realizar el ensayo de ELISA. Como controles negativos y positivos se utilizó MEM sin y con un $30 \%$ de SFB respectivamente. Nivel de significancia del test t de Student en comparación con el control negativo: $P<0,05,{ }^{* *} P<0,01 y{ }^{* * *} P<0,001$.

Como se observa en la fig 4-2, tanto las rHDL de distinto tamaño y composición, como la apoA-I libre de lípidos se unieron a la membrana celular dando diferencias significativas respecto del control. Salvo algunas diferencias menores, este comportamiento fue prácticamente independiente del tamaño y contenido de colesterol de las dHDL.

\subsubsection{Eflujo de colesterol}

En células cargadas con colesterol o estimuladas con $\mathrm{H}$-Col y $\mathrm{AR}$ el eflujo de colesterol se lleva a cabo principalmente vía transportador ABCA1 y ABCG1 (Adorni y col., 2007; Lund-Katz y Phillips, 2010). Se ha propuesto que la apoA-I como las dHDL de tamaño pequeño (78 $\AA$ ), interaccionan con el transportador 
ABCA1 y que las de mayor tamaño (96 y $120 \AA$ ) lo harían con el ABCG1 (Favari y col.2009).

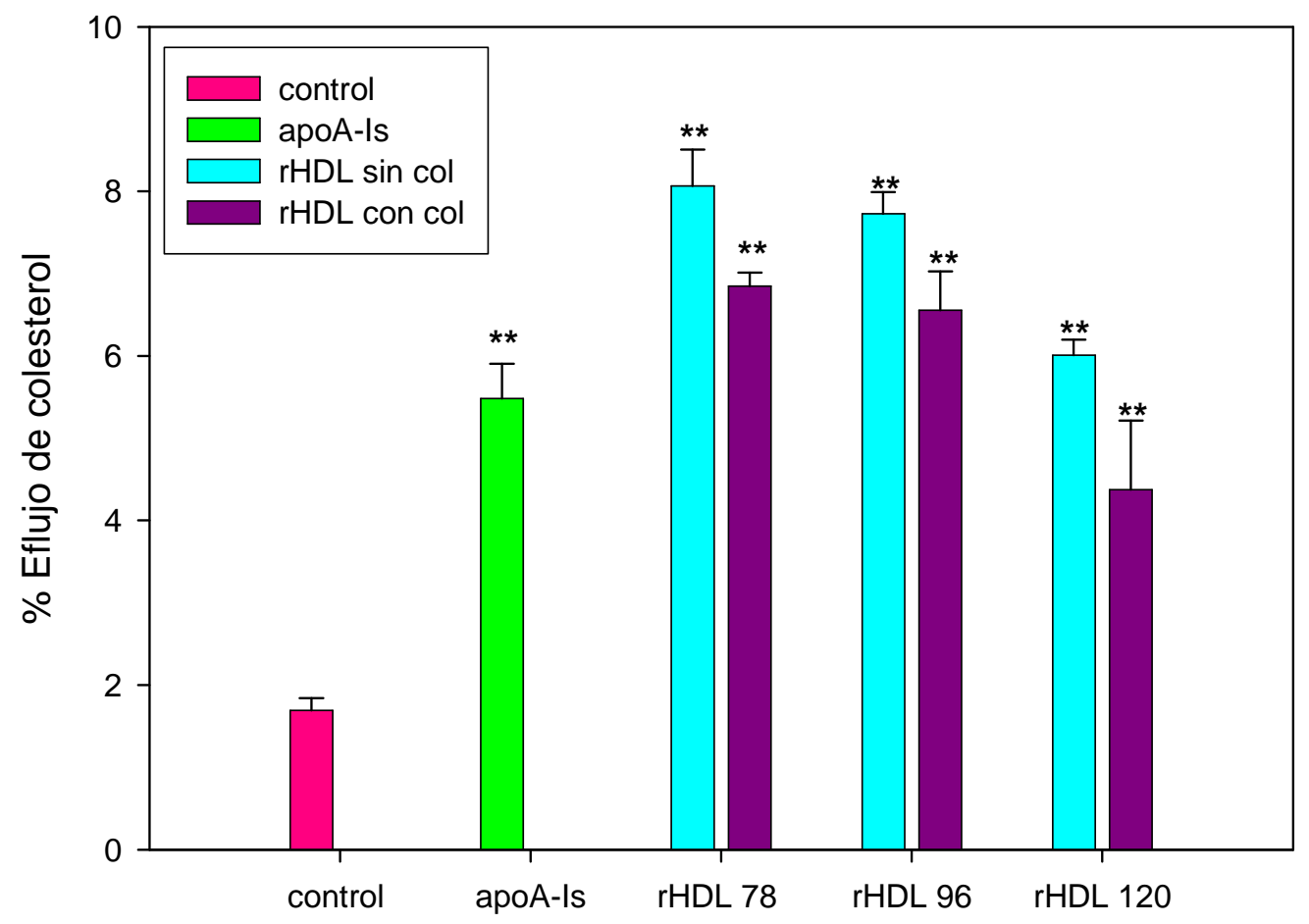

Figura 4-3. Eflujo de Colesterol en células CHO-K1. Las células fueron cargadas durante $24 \mathrm{~h}$ con 50 $\mu \mathrm{g} / \mathrm{ml}$ de colesterol y $0,05 \mu \mathrm{Ci} / \mathrm{ml}$ de $\left[{ }^{14} \mathrm{C}\right]$ colesterol en medio MEM sin SFB, complementado con $2 \mathrm{mg} / \mathrm{ml}$ de BSA. Luego se agregó una solución de equilibrado en medio DMEM sin SFB, con $1 \mathrm{mg} / \mathrm{ml}$ de BSA y se incubó por $8 \mathrm{~h}$. Finalizada la incubación se agregaron las diferentes rHDL y la apoA-I a una concentración de $12 \mu \mathrm{g} / \mathrm{ml}$ en medio MEM sin SFB durante $12 \mathrm{~h}$. Los datos estadísticos se analizaron mediante test $t$ de Student, con niveles de significancia en comparación con el control de: ${ }^{*} \mathrm{P}<0,05$; ** $P<0,01 y{ }^{* \star *} P<0,001$.

En la fig. 4-3 se observa que la apoA-I como el resto de las partículas rHDL, removieron colesterol significativamente. Las rHDL de 78 y $96 \AA$ mostraron un mayor porcentaje de eflujo de colesterol, en comparación con la apoA-l y rHDL de $120 \AA$ A Se observó una tendencia a medida que se incrementa el tamaño de las rHDL disminuye el porcentaje de eflujo de colesterol, independientemente del contenido de colesterol en las partículas. La presencia previa de colesterol en las rHDL tiende a hacerlas menos efectivas para remover colesterol de estas células. 


\subsubsection{Distribución de radioactividad entre colesterol libre y esterificado}

Con el fin de explorar si el eflujo de colesterol promovido por apoA-I o las rHDL moviliza a los depósitos intracelulares de colesterol esterificado, se analizaron los lípidos de las monocapas celulares, determinando la relación de radioactividad asociada a las fracciones de colesterol libre y colesterol esterificado.

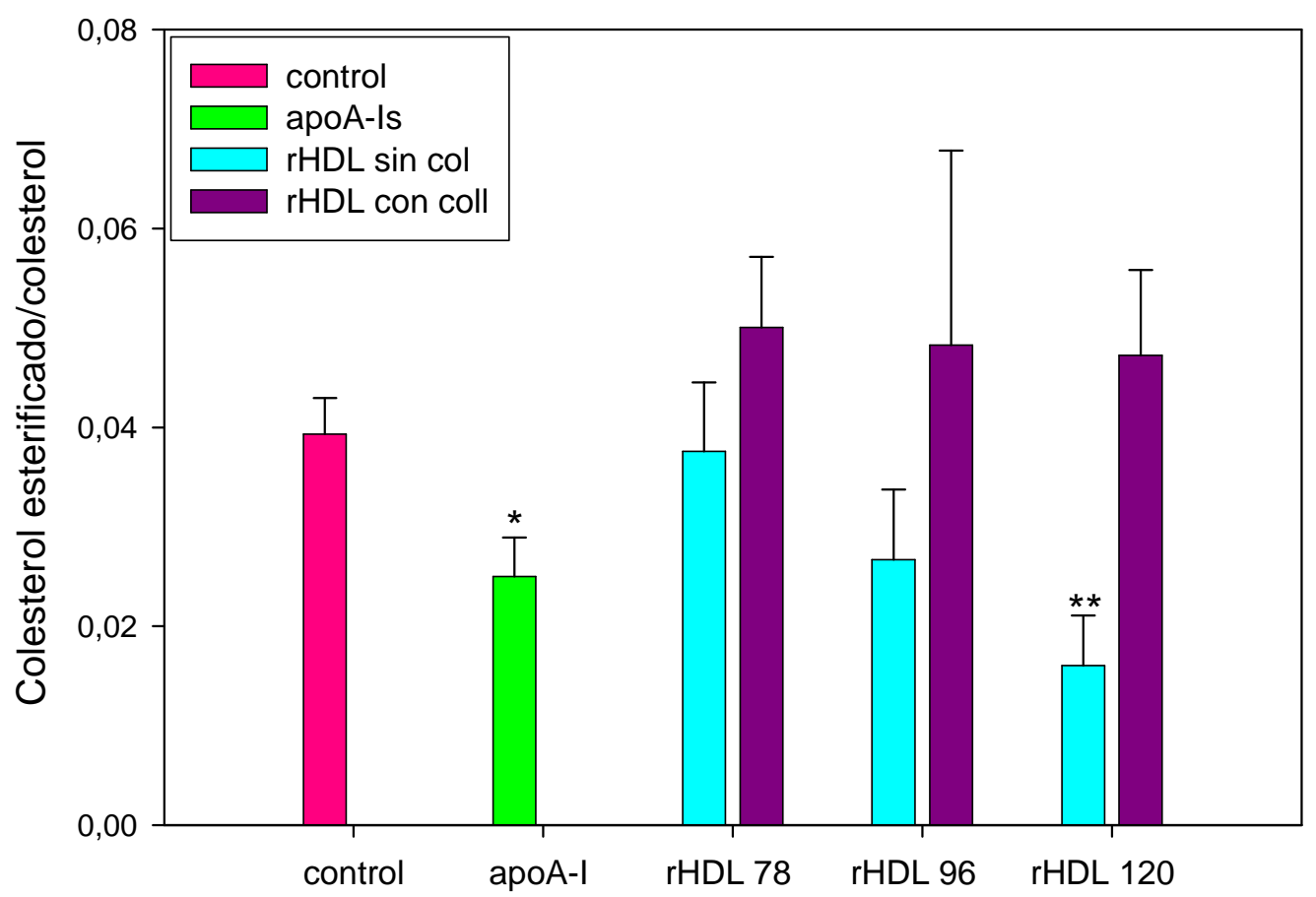

Figura 4-4. Influencia del tratamiento con apoA-I o rHDL sobre la relación de radioactividad entre las fracciones de colesterol esterificado y colesterol libre en células $\mathrm{CHO}-\mathrm{K} 1$. Las células fueron cargadas durante $24 \mathrm{~h}$ con $50 \mu \mathrm{g} / \mathrm{ml}$ de colesterol y $0,05 \mu \mathrm{Ci} / \mathrm{ml}\left[{ }^{14} \mathrm{C}\right]$ colesterol en medio MEM sin SFB, complementado con $2 \mathrm{mg} / \mathrm{ml}$ de BSA. Luego se agregó una solución de equilibrado en medio MEM sin SFB con $1 \mathrm{mg} / \mathrm{ml}$ de BSA y se incubó por $8 \mathrm{~h}$. Finalizada la incubación se agregaron las diferentes rHDL y la apoA-I a una concentración de $12 \mu \mathrm{g} / \mathrm{ml}$ en medio MEM durante $12 \mathrm{~h}$. Luego se extrajeron los lípidos de las monocapas celulares mediante Bligh \& Dyer y se separaron por TLC. Seguidamente se estableció la relación CE/col. mediante el Image Quant (Storm). Los datos estadísticos se analizaron mediante el test $t$ de Student, que arrojó los siguientes niveles de significancia respecto del control: * $\mathrm{P}<0,05$; * $P<0,01 y{ }^{* * *} P<0,001$.

Como puede observarse en la fig. 4-4, las rHDL con colesterol, independientemente del tamaño, mantuvieron constante la relación CE/col. y no mostraron diferencias significativas con respecto al control. Por otro lado, la apoA-I disminuyó significativamente la relación de radioactividad en $\mathrm{CE} / \mathrm{col}$. en 
comparación con el control y además se observó una tendencia en las rHDL sin colesterol a disminuir la relación de radioactividad en $\mathrm{CE} / \mathrm{col}$. a medida que se incrementaba su tamaño, haciéndose significativa esta disminución para las rHDL de $120 \AA$.

\subsubsection{Eflujo de fosfolípidos de colina}

El siguiente experimento se realizó con el objetivo de determinar el comportamiento de las rHDL y apoA-I a nivel del eflujo de fosfolípidos. Las células fueron cargadas con $50 \mu \mathrm{g} / \mathrm{ml}$ de colesterol y $0,5 \mu \mathrm{Ci}\left[{ }^{14} \mathrm{C}\right]$ fosforilcolina durante $24 \mathrm{~h}$. Luego se realizó un equilibrado, con el fin de equilibrar los pooles de colesterol, durante $8 \mathrm{~h}$ y finalmente se incubaron las células con $12 \mu \mathrm{g} / \mathrm{ml}$ de partículas rHDL o apoA-I por $12 \mathrm{~h}$.

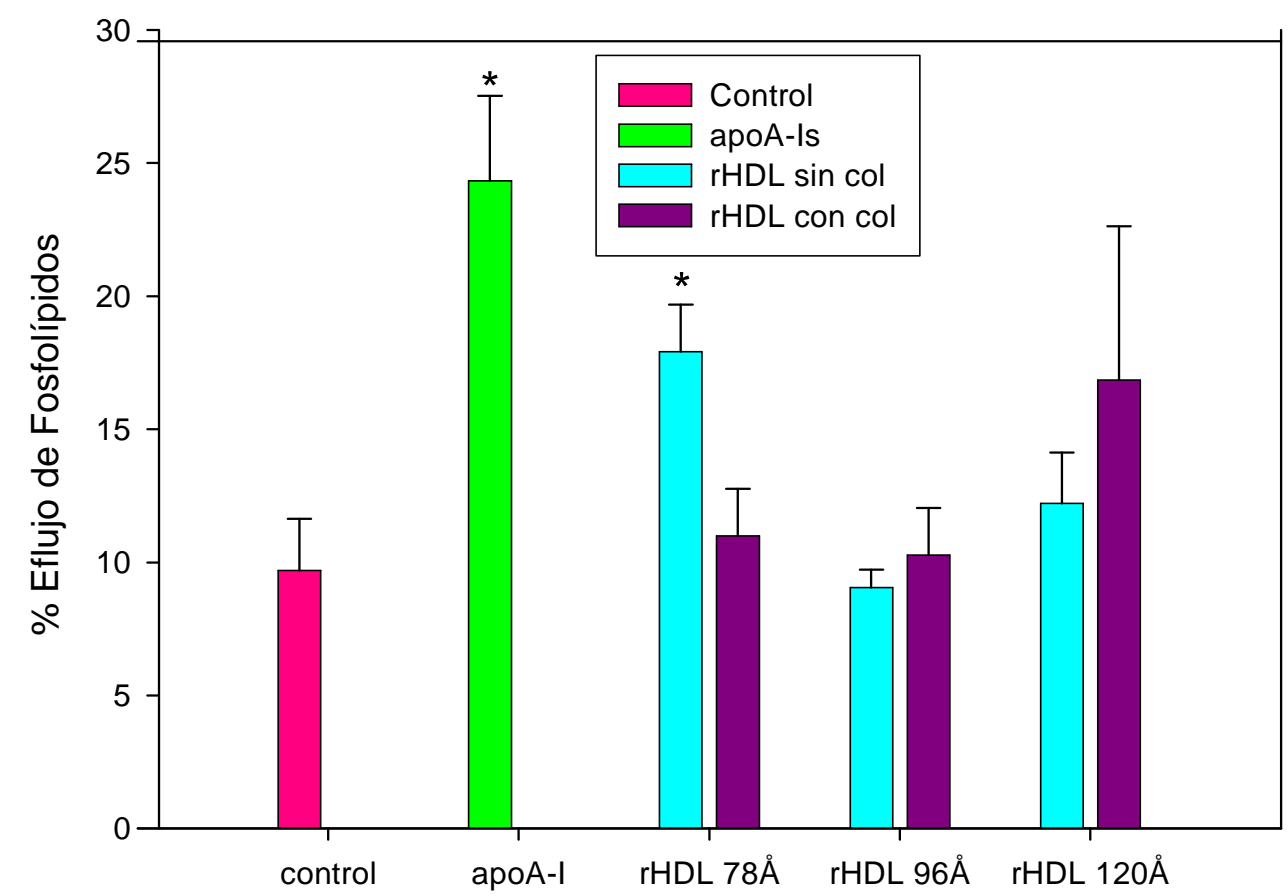

Figura 4-5. Eflujo de fosfolípidos en células CHO-K1. Las células fueron cargadas con colesterol $50 \mu \mathrm{g} / \mathrm{ml}$ y $0,5 \mu \mathrm{Ci}$ de $\left[{ }^{14} \mathrm{C}\right]$-fosforilcolina en medio MEM sin SFB, complementado con $2 \mathrm{mg} / \mathrm{ml}$ de BSA durante 24 h. Luego se agregó una solución de equilibrado en medio MEM sin SFB con $1 \mathrm{mg} / \mathrm{ml}$ de BSA y se incubó 8 h. Finaliza la incubación se agregó apoA-I o las rHDL, a una concentración de $12 \mu \mathrm{g} / \mathrm{ml}$ en medio MEM sin suero y se incubó durante $12 \mathrm{~h}$. Niveles de significancia de la diferencia con el control, según el test $\mathrm{t}$ de Student: ${ }^{*} P<0,05 ;{ }^{* *} P<0,01 y$ ** $P<0,001$.

Como se observa en la fig. 4-5 tanto la apoA-I como las rHDL $78 \AA$ removieron significativamente fosfolípidos de colina. Además la apoA-I removió el mayor 
porcentaje de fosfolípidos. Las rHDL de 96 y $120 \AA$ en cambio, fueron inactivas en este proceso y no removieron fosfolípidos de manera significativa.

\subsubsection{Distribución de radioactividad entre fosfatidilcolina (PC) y esfingomielina (SM)}

Para determinar qué especies de fosfolípidos de colina eran removidos preferencialmente por la apoA-I y $\mathrm{rHDL}$, se extrajeron los lípidos tanto del medio como de las monocapas celulares mediante la técnica de Bligh \& Dyer y se separaron por TLC. Seguidamente la radioactividad en las especies fosfolipídicas fueron cuantificadas mediante el Image Quant (Storm) y la relación entre fosfatidilcolina (PC) y esfingomielina (SM) fue establecida.

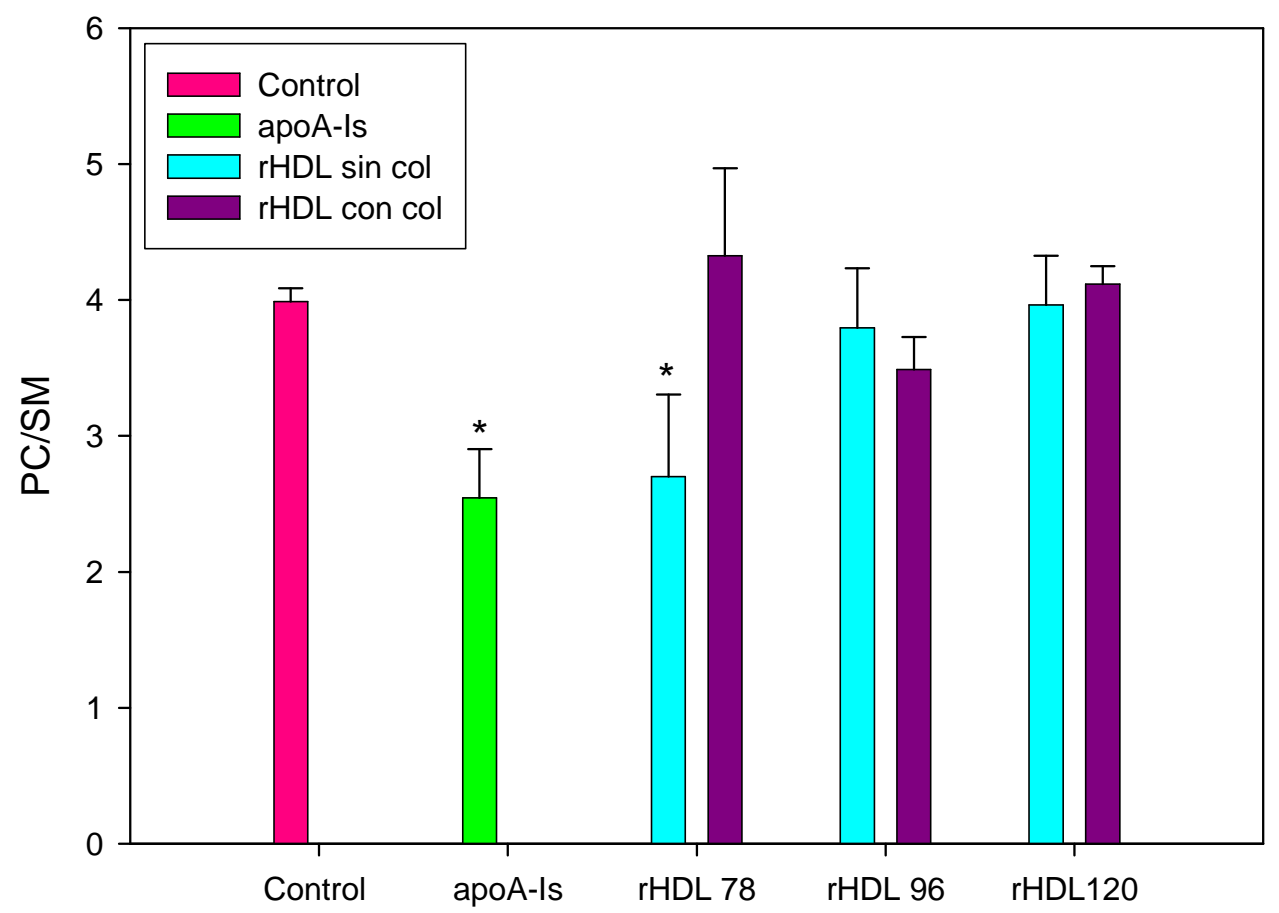

Figura 4-6. Efecto de apoA-I y las rHDL sobre la distribución de la radioactividad entre fosfatidilcolina y esfingomielina en células $\mathrm{CHO}-\mathrm{K} 1$. Las células fueron cargadas durante $24 \mathrm{~h}$ con $50 \mu \mathrm{g} / \mathrm{ml}$ de colesterol y $0,5 \mu \mathrm{Ci}\left[{ }^{14} \mathrm{C}\right]$-fosforilcolina en medio MEM sin SFB, complementado con $2 \mathrm{mg} / \mathrm{ml}$ de BSA. Seguidamente se incubaron con una solución de equilibrado durante 8h y luego se agregó la apoA-I o las rHDL con y sin colesterol, a una concentración de $12 \mu \mathrm{g} / \mathrm{ml}$ en medio MEM sin SFB. Los lípidos celulares fueron extraídos mediante la técnica Bligh \& Dyer y se separaron los fosfolípidos de colina mediante TLC. Seguidamente se estableció la relación de radiactividad PC/SM mediante el Image Quant (Storm). Niveles de significancia, según el test $t$ de Student: * $P<0,05 ;{ }^{* *} P<0,01$ y ${ }^{* *} P<0,001$. 
En el caso del medio de cultivo sólo se detectó radioactividad en la fracción de PC, mientras que en el caso de los lípidos celulares, la radiactividad se distribuyó entre PC y SM de acuerdo a las relaciones indicadas en la figura 4-6. Se observó que la apoA-I como rHDL de $78 \AA$ sin col., removieron preferencialmente fosfatidilcolina en relación a esfingomielina. Estos datos se correlacionan con la mayor capacidad de remover fosfolípidos de colina. Con respecto a las rHDL de 96 y $120 \AA$, no remocionan significativamente fosfolípidos de colina, ni modificaron la distribución de radioactividad entre PC y SM.

\subsubsection{Comportamiento de dHDL en células RAW 264.7}

\subsubsection{Capacidad de unión a la membrana celular}

En el caso de las células RAW 264.7, el ensayo de ELISA para determinar la capacidad de unión a la membrana celular fue realizado a dos temperaturas (37 y $4^{\circ} \mathrm{C}$ ). Se ha propuesto que tanto apoA-I como las HDL pueden ser endocitadas en varios tipos de células, y este proceso es inhibido a bajas temperaturas. Así, las medidas 37 y $4^{\circ} \mathrm{C}$ podrían ayudar a distinguir entre la unión a la membrana y la endocitosis. Además, los ensayos de ELISA se realizaron sobre células pretratadas de dos maneras diferentes: a) con la combinación de hidroxicolesterol $(\mathrm{H}$-Col) y ácido 9-cis-retinoico (AR) que presumiblemente resulta en la inducción de los transportadores ABCA1 y ABCG1, y b) con 8-bromoadenosina-3-5-monofosfato cíclico (Br-AMPc), un análogo permeable del AMPc que presumiblemente induce la expresión y activación del ABCA1.

\subsection{Determinaciones a $37^{\circ} \mathrm{C}$ sobre células inducidas con H-Col y AR}

Las células fueron crecidas hasta alcanzar una confluencia del $80-90 \%$ y las monocapas fueron tratadas con $\mathrm{H}-\mathrm{Col}$ y AR durante $24 \mathrm{~h}$. Luego se retiró el medio de cultivo y se agregaron $48 \mu \mathrm{g} / \mathrm{ml}$ de apoA-l o rHDL de 78, 96 y $120 \AA$ con y sin col. y finalmente se las incubó durante $1 \mathrm{~h}$. a $37^{\circ} \mathrm{C}$ antes de realizar el ensayo de ELISA. El H-Col y AR son ligandos de los receptores LXR y RXR, estos receptores forman heterodímeros y funcionan como factores de 
transcripción que estimulan el eflujo de lípidos y la expresión de los transportadores ABCA1 y ABCG1 (Rader, 2006; Shiabata y Glass, 2010).

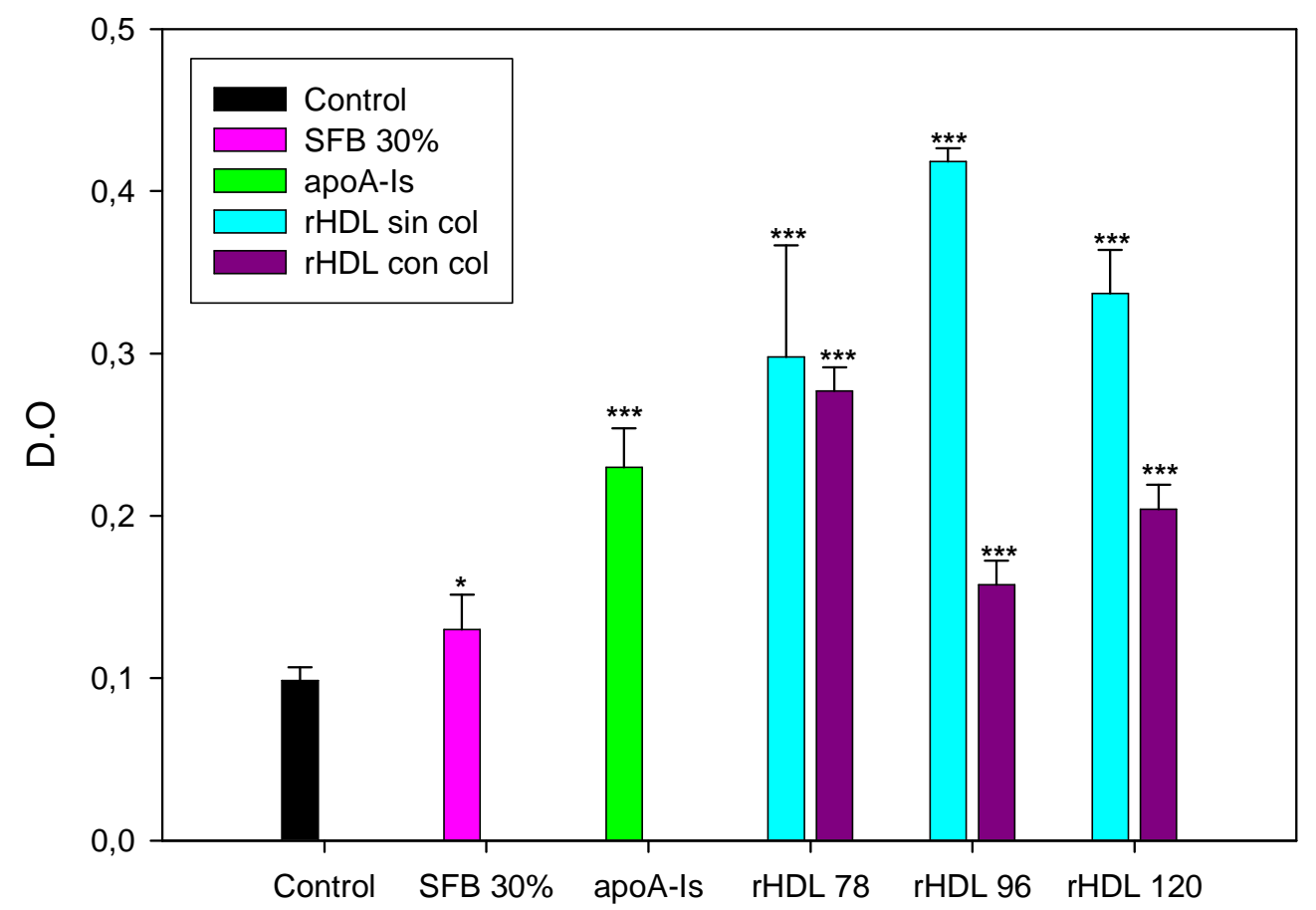

Figura 4-7. Unión de apoA-I y diferentes rHDL a la membrana de células RAW 264.7 a 37ํㅡ. Las células fueron activadas durante $24 \mathrm{~h}$ con $2,5 \mu \mathrm{g} / \mathrm{ml}$ de $\mathrm{H}$-Col y $0,75 \mu \mathrm{g} / \mathrm{ml}$ de $\mathrm{AR}$ a $37^{\circ} \mathrm{C}$ en medio DMEM sin SFB e incubadas con $48 \mu \mathrm{g} / \mathrm{ml}$ de apoA-I y rHDL 78, 96 y $120 \AA$ con y sin colesterol por 1 hora a la misma temperatura, antes de realizar el ensayo de ELISA. Como controles negativos y positivos se utilizó DMEM sin y con $30 \%$ de SFB respectivamente. Los datos se analizaron con test $t$ de Student, con los siguientes nivel de significancia respecto del control negativo: * $P<0,05$, ${ }^{* *} P<0,01$ y ${ }^{* *} P<0,001$.

Como puede verse en la fig. 4-7, se observó que todas las partículas de diferente tamaño y composición, al igual que la apoA-I no lipidada se unieron eficazmente a la membrana celular dando diferencias significativas respecto del control. En el caso de las rHDL de $78 \AA$ con y sin col., se comportaron de la misma manera y su capacidad de unión a la membrana celular fue similar al de la apoA-I. En este tipo de partícula la unión a la superficie celular fue independiente del contenido de colesterol. En el caso de las partículas de 96 y $120 \AA$ sin col., se comportaron de manera similar y se diferenciaron significativamente de sus pares con colesterol, mostrando una mayor capacidad de unión a membrana. El colesterol en estas partículas disminuyó la 
capacidad de unión. Las rHDL de 96 A sin colesterol presentaron la mayor capacidad de unión a la membrana celular.

\subsection{Determinaciones a $4^{\circ} \mathrm{C}$ sobre células pretratadas con $\mathrm{H}-\mathrm{Col}$ y $\mathrm{AR}$}

El tratamiento de las células RAW 264.7 fue similar al descripto arriba, sólo que la temperatura de incubación con apoA-I o las $\mathrm{rHDL}$ fue de $4^{\circ} \mathrm{C}$ para disminuir la fluidez de la membrana y evitar la internalización por endocitosis.

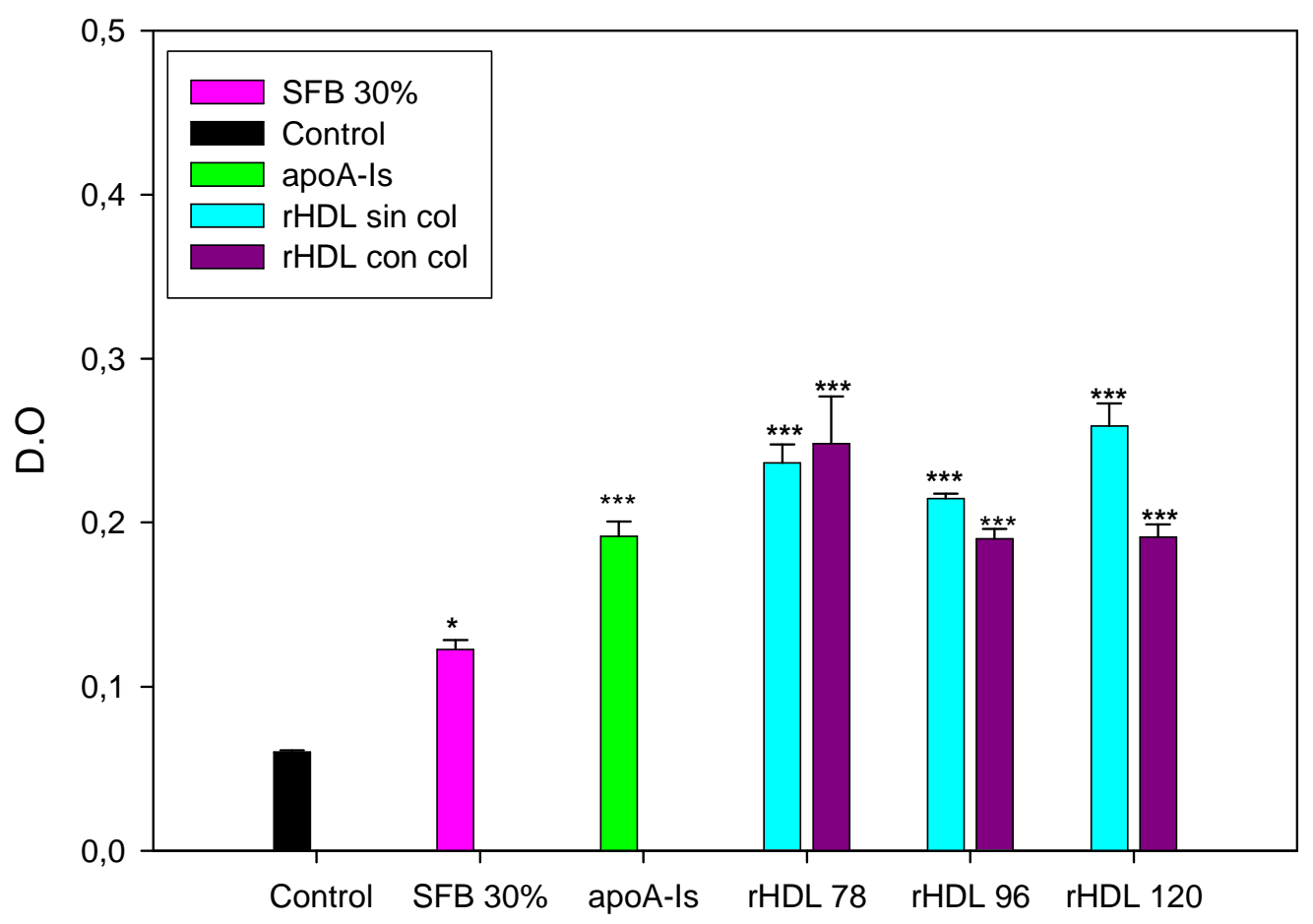

Figura 4-8. Capacidad de apoA-I y las diferentes rHDL para unirse a la membrana de células RAW 264.7 a $4 \stackrel{\circ}{\circ}$. Las células fueron crecidas y pretratadas con $\mathrm{H}-\mathrm{Col}$ y $\mathrm{AR}$ a $37^{\circ} \mathrm{C}$ como en el caso anterior, pero incubadas con $48 \mathrm{ug} / \mathrm{ml}$ de apoA-I o rHDL 78, 96 y $120 \AA \AA$ con y sin colesterol durante 1 hora a $4{ }^{\circ} \mathrm{C}$ antes de realizar el ensayo de ELISA. DMEM sin y con $30 \%$ de SFB se usó como control negativo y positivo, respectivamente. Niveles de significación respecto del control negativo según el test $t$ de Student: * $\mathrm{P}<0,05 ;{ }^{* *} \mathrm{P}<0,01 \mathrm{y}{ }^{* * *} \mathrm{P}<0,001$.

En la fig. 4-8 se observa que todas las partículas, así como la apoA-I libre de lípidos se unieron significativamente a la membrana celular, pero con menor eficiencia que a $37^{\circ} \mathrm{C}$. Al disminuir la temperatura de incubación, se observó principalmente una disminución significativa en la capacidad de unión a nivel rHDL $96 \AA$ sin col., que a $37^{\circ} \mathrm{C}$ mostraban la mayor capacidad de unión a membranas. En el caso de las partículas lipoproteicas de mayor tamaño (96 y 
$120 \AA$ A), se mantuvo la tendencia a una unión menos eficiente para las rHDL que contienen colesterol.

\subsection{Determinaciones de unión a la membrana celular a $37^{\circ} \mathrm{C}$ en células pretratadas con Br-AMPc}

El pretratamiento de células RAW 264.7 con 0,5 mM Br-AMPc llevó a un incremento en la capacidad de unión a la membrana por parte de la apoA-I y de las partículas $\mathrm{rHDL}$ de diferente tamaño y composición, en comparación con el pretratamiento con $\mathrm{H}-\mathrm{col}$ y $\mathrm{AR}$, como se observa en la fig.4-9. Todas las partículas $\mathrm{rHDL}$ como la apoA-I se unieron significativamente a la membrana. La apoA-I mostró la mayor capacidad de unión a membrana. Se observa una tendencia a aumentar la eficiencia de unión a la membrana al aumentar el tamaño de las rHDL, y en especial en el caso de las rHDL de mayor tamaño (96 y $120 \AA$ Å) la presencia de colesterol disminuyó la eficiencia de unión a la membrana celular, similarmente a lo ocurrido en el tratamiento con H-Col y AR.

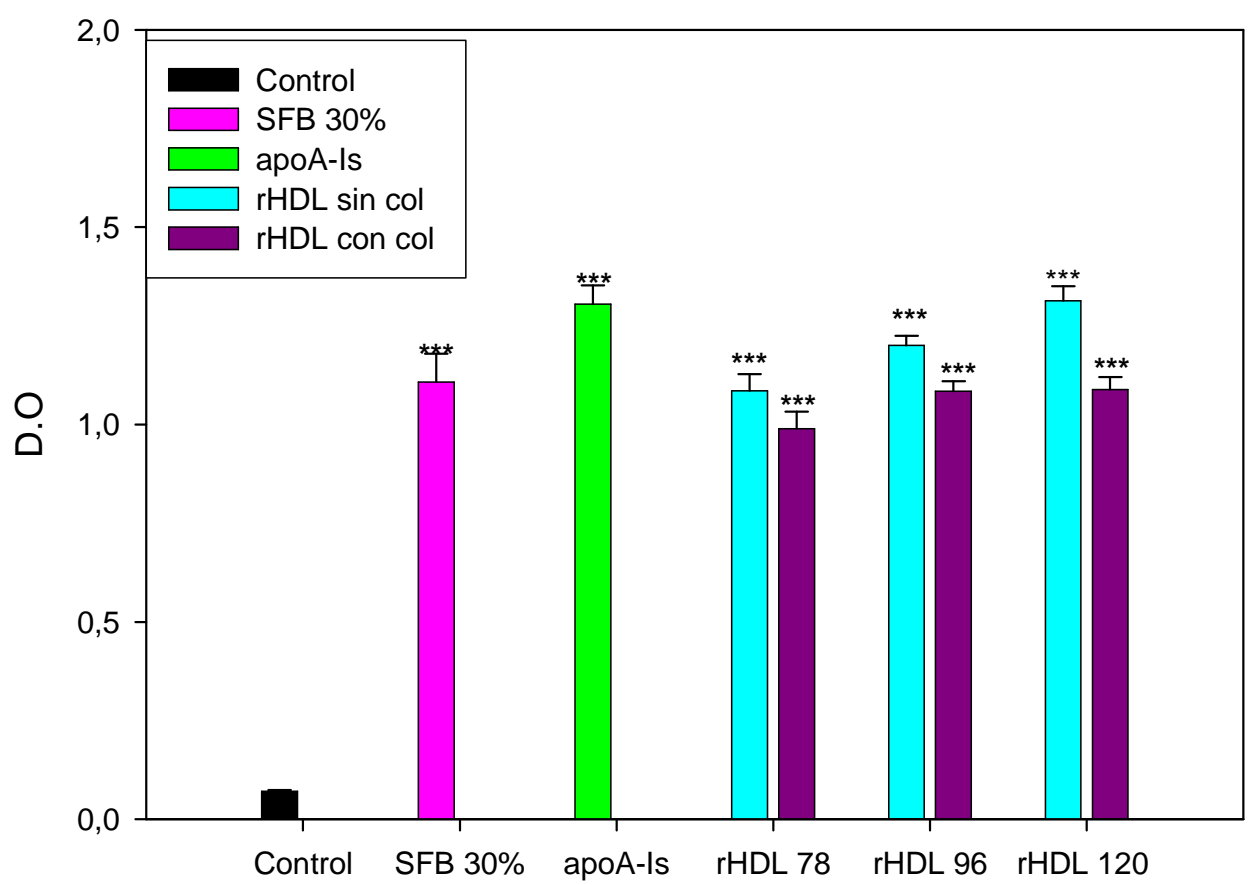

Figura 4-9. Capacidad de apoA-I y las diferentes rHDL para unirse a la membrana de células RAW 264.7 a $37^{\circ} \mathrm{C}$. Las células fueron crecidas y pretratadas con $0,5 \mathrm{mM} \mathrm{Br}-\mathrm{AMPc}$ a $37^{\circ} \mathrm{C}$ e incubadas con $48 \mathrm{ug} / \mathrm{ml}$ de apoA-I o rHDL 78, 96 y $120 \AA$ con y sin colesterol durante 1 hora a la misma temperatura, antes de realizar el ensayo de ELISA. Se utilizó DMEM sin y con $30 \%$ de SFB, como control negativo y positivo respectivamente. Los datos se analizaron con test $t$ de Student, con los siguientes nivel de significancia respecto del control negativo: ${ }^{*} \mathrm{P}<0,05$, ${ }^{* *} \mathrm{P}<0,01 \mathrm{y}{ }^{* * *} \mathrm{P}<0,001$. 


\subsection{Determinaciones de unión a la membrana celular a $4^{\circ} \mathrm{C}$ en células pretratadas con Br-AMPc}

La disminución de la temperatura a $4^{\circ} \mathrm{C}$ afectó la capacidad de unión de la apoA-I y rHDL de distinto tamaño y composición, si bien se asociaron significativamente a membranas se observó una disminución en su afinidad a membranas en comparación con el tratamiento a $37^{\circ} \mathrm{C}$ con Br-AMPc. La disminución de la fluidez de la membrana afectó la interacción de las apoA-I y de las rHDL. A diferencia de lo que ocurrió a $37^{\circ} \mathrm{C}$, se observa una tendencia a disminuir la capacidad de unión a medida que aumenta el tamaño de las rHDL; y en el caso de las rHDL de 78 y $96 \AA$ se mantiene la tendencia a disminuir la capacidad de unión por la presencia previa de colesterol en las partículas lipoproteicas.

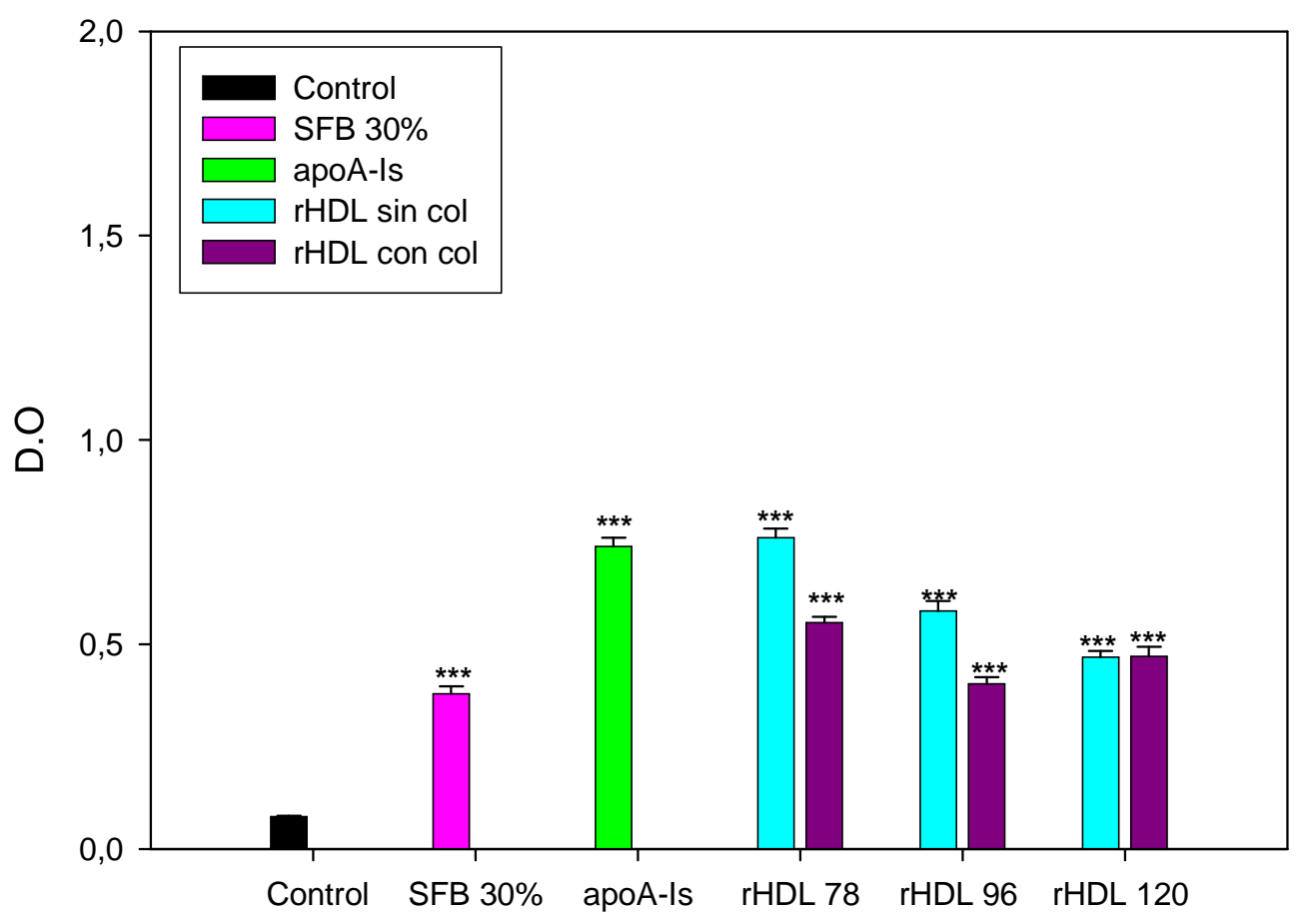

Figura 4-10. Capacidad de apoA-I y las diferentes rHDL para unirse a la membrana de células RAW 264.7 a $4 \stackrel{\circ}{\circ}$. Las células fueron crecidas y pretratadas con $0,5 \mathrm{mM} B r-A M P c$ al igual que en el caso anterior, pero incubadas con $48 \mathrm{ug} / \mathrm{ml}$ de apoA-I o rHDL 78, 96 y $120 \AA$ con y sin colesterol durante 1 hora a $4{ }^{\circ} \mathrm{C}$ antes de realizar el ensayo de ELISA. DMEM sin y con $30 \%$ de SFB, se utilizó como control negativo y positivo, respectivamente. Los datos se analizaron según test $t$ de Student con los siguientes niveles de significación, respecto del control negativo * $P<0,05 ;{ }^{* *} P<0,01$ y ${ }^{* *} P<0,001$. 


\subsubsection{Eflujo de colesterol}

\subsection{Pretratamiento con H-Col y AR}

Las células fueron cargadas con $50 \mu \mathrm{g} / \mathrm{ml}$ de colesterol, y $0,05 \mu \mathrm{Ci} / \mathrm{ml}\left[{ }^{14} \mathrm{C}\right]$ colesterol durante $24 \mathrm{~h}$, luego se las equilibró y activó con $2,5 \mu \mathrm{g} / \mathrm{ml} \mathrm{H}$-Col y $0,75 \mu \mathrm{g} / \mathrm{ml}$ AR. Finalizado el equilibrado se trataron a las células con $12 \mu \mathrm{g} / \mathrm{ml}$ de rHDL de 78, 96, y $120 \AA$ A con y sin colesterol.

Todas las rHDL removieron significativamente colesterol con respecto al control. Pero la apoA-I frente a la activación con $\mathrm{H}-\mathrm{Col}$ y $\mathrm{AR}$, no presentó diferencias significativas respecto del colesterol. En estas condiciones, ni el tamaño ni el contenido de colesterol de las rHDL afectaron mayormente su capacidad de promover eflujo de colesterol.

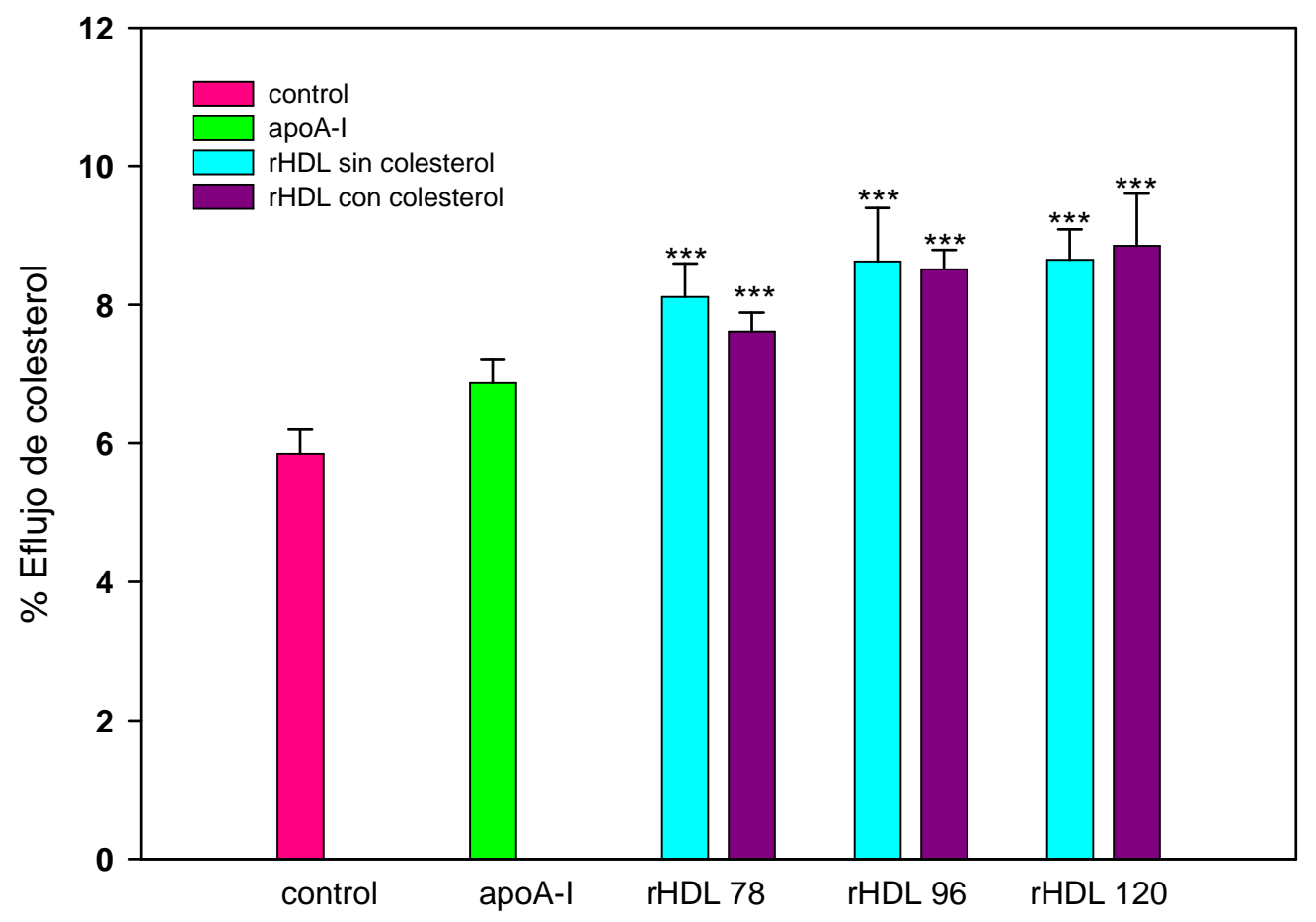

Figura 4-11. Eflujo de Colesterol en células RAW 264.7 pretratadas con H-Col y AR. Las células fueron cargadas durante $24 \mathrm{~h}$ con $50 \mu \mathrm{g} / \mathrm{ml}$ de colesterol y $0,05 \mu \mathrm{Ci} / \mathrm{ml}\left[{ }^{14} \mathrm{C}\right]$ colesterol en medio DMEM sin SFB suplementado con $2 \mathrm{mg} / \mathrm{ml}$ BSA. Luego se agregó una solución de equilibrado, con $1 \mathrm{mg} / \mathrm{ml}$ de BSA y se pretataron con $\mathrm{H}$-Col y AR durante 8h. Finalizada la incubación se agregaron las diferentes rHDL y apoAI a una concentración de $12 \mu \mathrm{g} / \mathrm{ml}$ en medio DMEM sin SFB con H-Col y AR. Los datos se analizaron mediante test $t$ de Student con un nivel de significancia con respecto al control de: ${ }^{*} \mathrm{P}<0,05,{ }^{* *} \mathrm{P}<0,01$ y *** $P<0,001$. 


\subsection{Pretratamiento con Br-AMPc}

Como se describió anteriormente, las células fueron cargadas con $50 \mu \mathrm{g} / \mathrm{ml}$ de colesterol, y $0,05 \mu \mathrm{Ci} / \mathrm{ml}\left[{ }^{14} \mathrm{C}\right]$ colesterol durante $24 \mathrm{~h}$, luego se las equilibró y activó con 0,5 mM de Br-AMPc. Finalizado el equilibrado se trataron a las células con $12 \mu \mathrm{g} / \mathrm{ml}$ de rHDL de 78, 96, y $120 \AA$ con y sin colesterol. Todas las partículas testeadas como así también la apoA-I removieron colesterol significativamente, aumentando notoriamente las diferencias con el control en comparación con el pretratamiento con H-Col + AR. La rHDL de $96 \AA$ sin colesterol mostró la mayor capacidad de eflujo de colesterol, la que fue decrecida por la incorporación de colesterol en la partícula lipoproteica. Esta influencia del colesterol en las partículas lipoproteicas se observa en menor grado en las rHDL de $78 \AA$, pero desaparece e incluso se invierte en el caso de las de $120 \AA$ A. En cuanto a la influencia del tamaño de las partículas lipoproteicas, no tuvo efecto alguno en el caso de las rHDL con colesterol. En el caso de las rHDL sin colesterol, en cambio, el eflujo de colesterol se incrementó al pasar de las rHDL de 78 a $96 \AA ̊$, y volvió a decrecer para las de $120 \AA$.

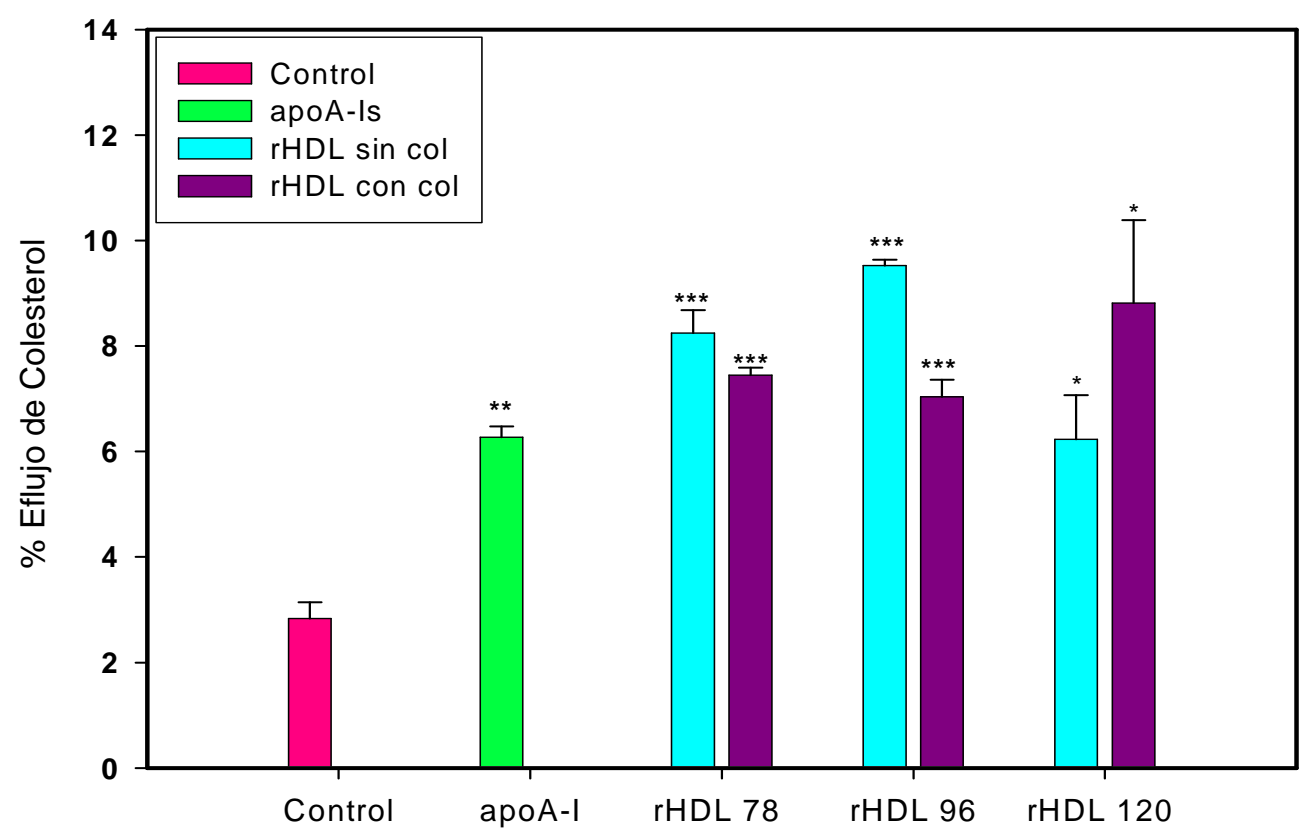

Figura 4-12. Eflujo de Colesterol en células RAW 264.7 pretratadas con Br-AMPc. Las células fueron cargadas durante $24 \mathrm{~h}$ con $50 \mu \mathrm{g} / \mathrm{ml}$ de colesterol y $0,05 \mu \mathrm{Ci} / \mathrm{ml}\left[{ }^{14} \mathrm{C}\right]$ colesterol en medio DMEM sin SFB complementado con $2 \mathrm{mg} / \mathrm{ml}$ de BSA. Luego se agregó una solución de equilibrado en medio DMEM sin SFB, con $1 \mathrm{mg} / \mathrm{ml}$ de BSA y 0,5 mM Br-AMPc, y se incubó $8 \mathrm{~h}$. Finalizada la incubación se agregaron la apoA-I y rHDL a una concentración de $12 \mu \mathrm{g} / \mathrm{ml}$ en medio DMEM sin SFB, con 0,5 mM Br-AMPc y se incubó durante $12 \mathrm{~h}$. Niveles de significancia: ${ }^{*} \mathrm{P}<0,05 ;{ }^{* *} \mathrm{P}<0,01 \mathrm{y}{ }^{* *} \mathrm{P}<0,001$. 


\subsubsection{Distribución de radioactividad entre colesterol libre y esterificado}

Con el fin de evaluar el comportamiento de la apoA-I y rHDL sobre los depósitos celulares de CE y el pool de colesterol libre (col.) se extrajeron los lípidos celulares y se realizó la separación de lípidos neutros, TLC. Seguidamente se estableció la relación de radioactividad entre las fracciones lipídicas de ésteres de colesterol y colesterol mediante el Image Quant (Storm). A nivel de las rHDL de mayor tamaño (96 y $120 \AA$ ) se observó una tendencia a incrementar la relación $\mathrm{CE} / \mathrm{col}$, independientemente del contenido de colesterol, siendo significativa para las $\mathrm{rHDL}$ de $96 \AA$ con col. Por otro lado la apoA-I como la rHDL de $78 \AA$, se comportaron de la misma manera que el control, no se vio una variación significativa en la relación $\mathrm{CE} / \mathrm{col}$.

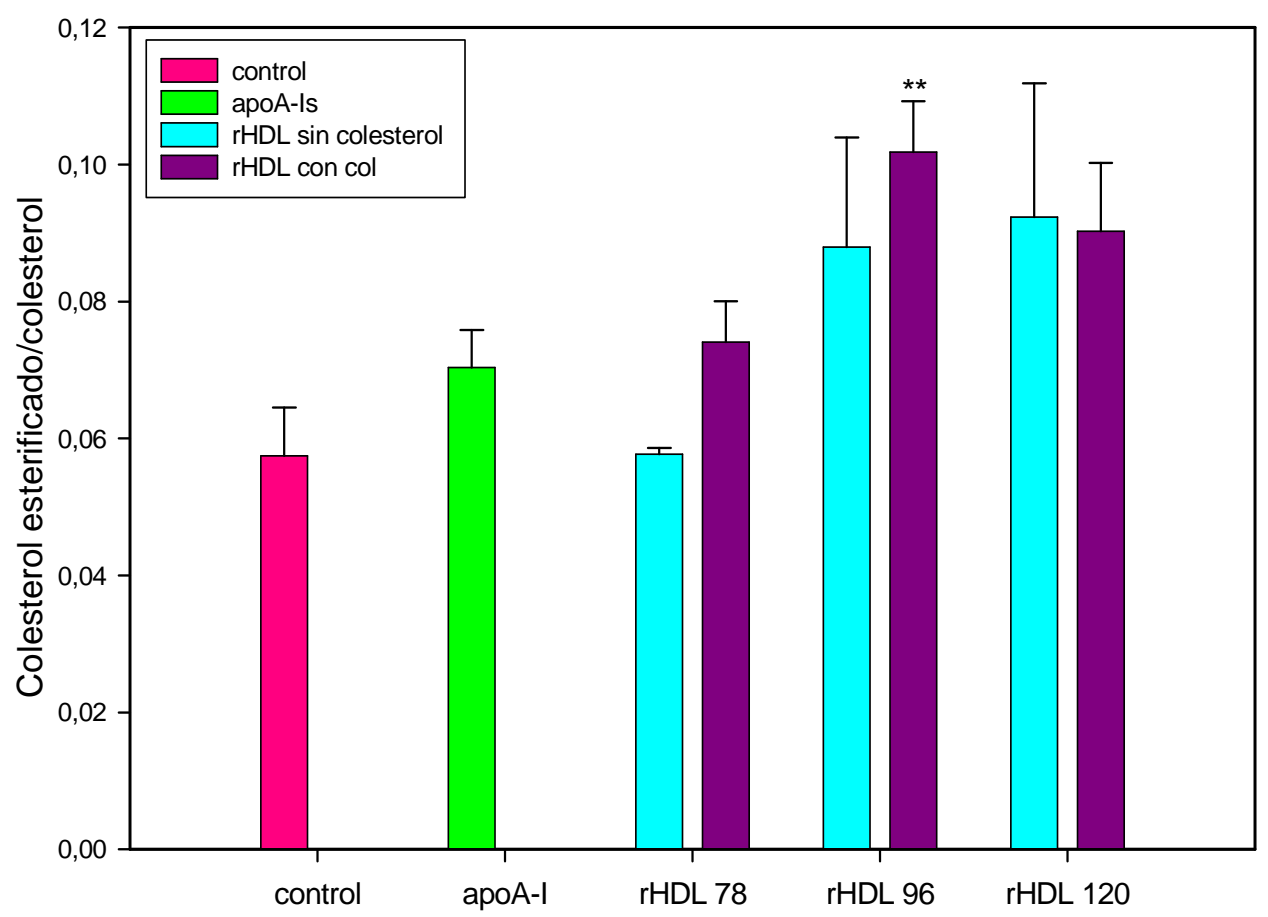

Figura 4-13. Influencia del tratamiento con apoA-I o rHDL sobre la relación de radioactividad entre las fracciones de colesterol esterificado y colesterol libre en células RAW 264.7. Las células fueron cargadas durante $24 \mathrm{~h}$ con $50 \mu \mathrm{g} / \mathrm{ml}$ de colesterol y $0,05 \mu \mathrm{Ci} / \mathrm{ml}\left[{ }^{14} \mathrm{C}\right]$ colesterol en medio DMEM sin SFB, complementado con $2 \mathrm{mg} / \mathrm{ml}$ de BSA. Seguidamente se agregó una solución de equilibrado durante $8 \mathrm{~h}$. Luego se incubaron las células con las rHDL o apoA-I a una concentración de $12 \mu \mathrm{g} / \mathrm{ml}$ por $12 \mathrm{~h}$. Finalmente se extrajeron los lípidos de las monocapas celulares mediante Bligh \& Dyer y se separaron mediante TLC y se estableció la relación CE/col. mediante el Image Quant (Storm). Los datos estadísticos se analizaron mediante el test $\mathrm{t}$ de Student, con los siguientes niveles de significancia respecto del control: * $\mathrm{P}<0,05 ;{ }^{* *} \mathrm{P}<0,01 \mathrm{y}{ }^{* * *} \mathrm{P}<0,001$. 


\subsubsection{Eflujo de fosfolípidos de colina}

A fin de determinar el comportamiento de las partículas sobre el eflujo de fosfolípidos en células RAW 264.7, se cargaron previamente las células con 0,5 $\mu \mathrm{Ci}\left[{ }^{14} \mathrm{C}\right.$ ] fosforilcolina, $50 \mu \mathrm{g} / \mathrm{ml}$ de colesterol durante $24 \mathrm{~h}$., luego se las equilibró y activó con $0,5 \mathrm{mM}$ de Br-AMPc. Finalizado el equilibrado las células fueron incubadas con $12 \mu \mathrm{g} / \mathrm{ml}$ de rHDL de 78, 96, y $120 \AA$ con y sin colesterol. La apoA-I mostró el mayor porcentaje de eflujo de fosfolípidos de colina, seguido por la rHDL de $78 \AA$. Casi todas las rHDL de mayor tamaño (96 y 120 A) removieron significativamente fosfolípidos, con la excepción de la rHDL de $96 \AA \sin$ col. Se observó una tendencia de que las rHDL con colesterol removieron un porcentaje mayor de fosfolípidos, en comparación con sus pares sin colesterol.

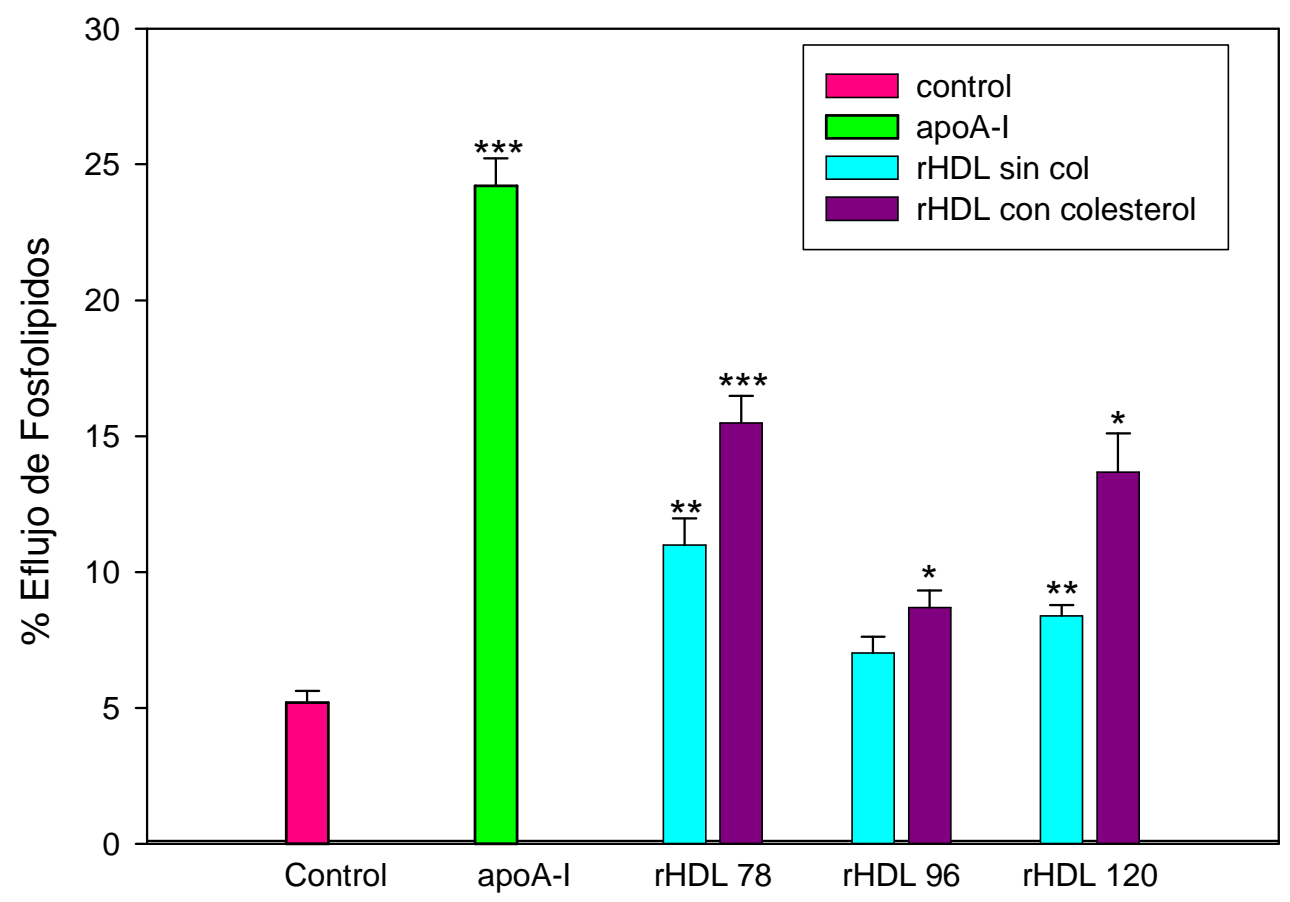

Figura 4-14. Eflujo de fosfolípidos en células RAW 264.7. Las células fueron cargadas con colesterol 50 $\mu \mathrm{g} / \mathrm{ml}$ y $0,5 \mu \mathrm{Ci}\left[{ }^{14} \mathrm{C}\right.$ ] fosforilcolina en medio DMEM sin SFB, complementado con $2 \mathrm{mg} / \mathrm{ml}$ de BSA durante $24 \mathrm{~h}$. Luego se agregó una solución de equilibrado, con $1 \mathrm{mg} / \mathrm{ml}$ de BSA y 0,5 mM Br-AMPc, y se incubó 8 h. Finalizada la incubación se agregaron las rHDL de 78, 96 y $120 \AA$ Å con y sin colesterol, a una concentración de $12 \mu \mathrm{g} / \mathrm{ml}$ en medio DMEM sin SFB con 0,5 mM Br-AMPc durante $12 \mathrm{~h}$. Los datos estadísticos se analizaron mediante test $t$ de Student, con niveles de significancia en comparación con el control de: * $P<0,05 ;{ }^{* *} P<0,01$ y ${ }^{\star * *} P<0,001$. 


\subsubsection{Distribución de radioactividad entre fosfatidilcolina (PC) y esfingomielina (SM)}

Con el objetivo de determinar las especies de fosfolípidos de colina que fueron removidos por la apoA-I y rHDL de distinto tamaño y composición, se extrajeron los lípidos celulares por medio de técnica de Bligh \& Dyer y se separaron por TLC. Luego se estableció la relación de radioactividad entre PC y SM mediante el Image Quant (Storm). Se observó que la apoA-I como todas las rHDL, tendieron a disminuir la relación de radioactividad en PC/SM.

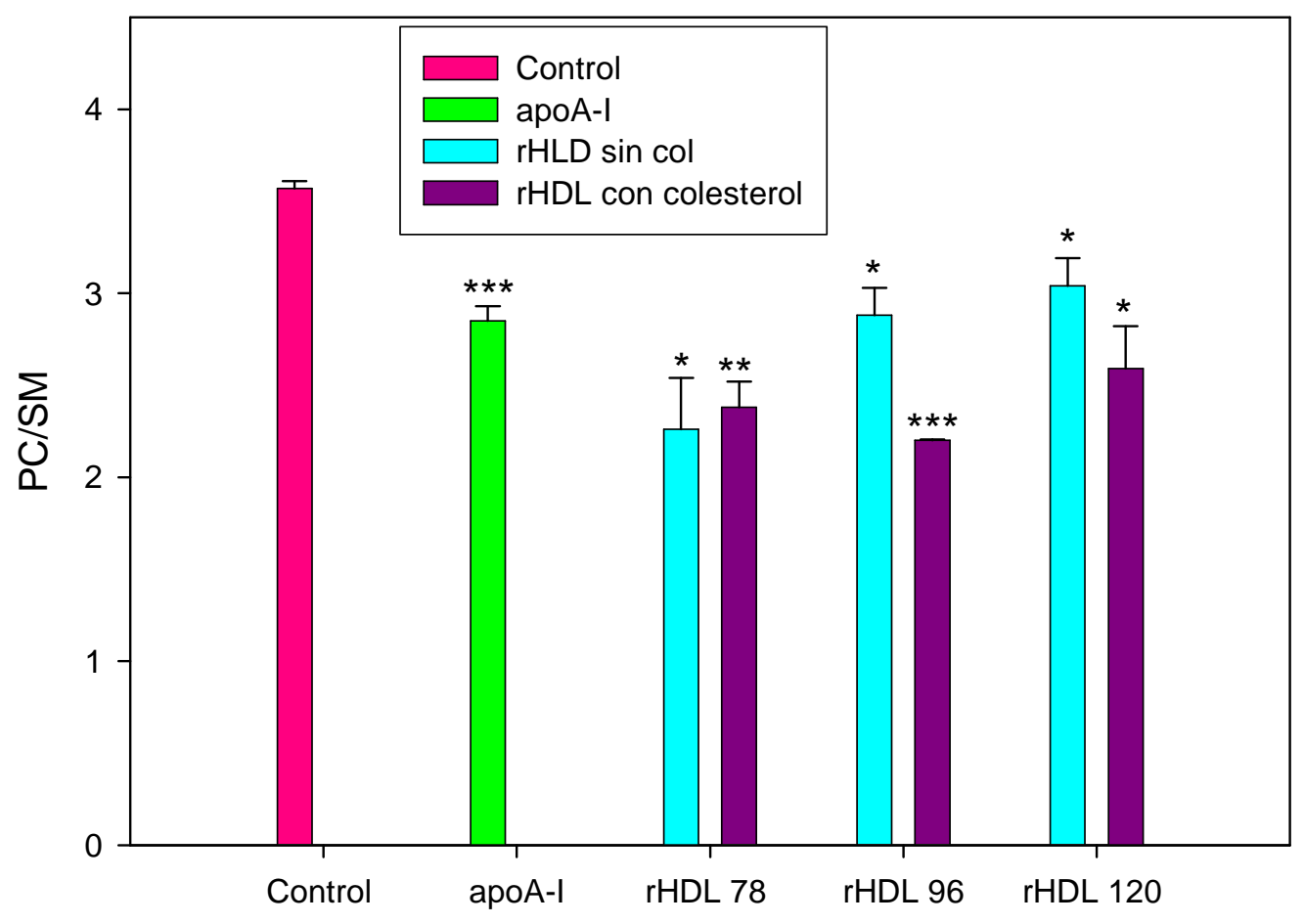

Figura 4-15. Relación de radioactividad entre las fracciones de PC y SM en células RAW 264.7. Las células fueron cargadas durante $24 \mathrm{~h}$ con $50 \mu \mathrm{g} / \mathrm{ml}$ de colesterol y $0,5 \mu \mathrm{Ci}\left[{ }^{14} \mathrm{C}\right.$ ] fosforilcolina en medio DMEM sin SFB complementado con $2 \mathrm{mg} / \mathrm{ml}$ de BSA. Luego se agregó la solución de equilibrado durante 8h. Seguidamente se probaron las diferentes $\mathrm{rHDL}$ y apoA-I a una concentración de $12 \mu \mathrm{g} / \mathrm{ml}$ en medio DMEM sin SFB con 0,5 mM de Br-AMPc I. Los lípidos celulares fueron extraídos mediante la técnica Bligh \& Dyer y se separaron los fosfolípidos de colina mediante TLC. Finalmente se estableció la relación de radioactividad entre las fracciones de PC y SM mediante el Image Quant (Storm). Los datos estadísticos se analizaron mediante test $t$ de Student, con niveles de significancia de las diferencias con respecto al control de: * $P<0,05 ;{ }^{* *} P<0,01 y{ }^{* * *} P<0,001$. 


\subsection{DISCUSIÓN}

\subsubsection{Capacidad de unión a membrana}

Los ensayos de unión a membrana llevados a cabo en células CHO-K1 y RAW 264.7 se realizaron con el fin de relacionar la capacidad de unión con el eflujo de lípidos. Todas las partículas rHDL como así también la apoA-I se unieron significativamente a membranas en ambos tipos celulares. En células $\mathrm{CHO}-\mathrm{K} 1$ estimuladas con $\mathrm{H}$-Col y $\mathrm{AR}$, se observó un comportamiento similar por parte de la apoA-I y rHDL de distinto tamaño y composición. En células RAW 264.7 pretratadas con $\mathrm{H}-\mathrm{Col}$ y $\mathrm{AR}$, se observó un comportamiento diferente por parte de la apoA-I y rHDL, la capacidad de unión se vio incrementada en comparación con CHO-K1.

Los diferentes mecanismos encontrados entre ambas células pueden deberse al metabolismo particular de cada tipo celular y a los distintos niveles de expresión de los transportadores ABCA1 y ABCG1.

En células RAW 264.7 las rHDL de $78 \AA$, independientemente de su contenido de colesterol, se comportaron de manera similar a la apoA-I. La capacidad de unión en estas partículas, no se vio afectada por el colesterol; esto puede ser debido a su interacción con el transportador ABCA1 (Favari y col., 2009), que cumple la función principal de transferir fosfolípidos hacia la apoA-I o dHDL de tamaño pequeño (Oram y Vaughan, 2006), y la presencia de colesterol en las partículas no afectaría la interacción con el transportador. En el caso de las rHDL de 96 y $120 \AA$ la interacción con membranas, fue dependiente de la composición. Las partículas reconstituidas sin colesterol, mostraron una mayor capacidad de unión a membrana, en comparación con sus pares con colesterol, quizás esta diferencia pueda deberse a la interacción con el transportador ABCG1 que cumple como función principal transferir colesterol (Oram y Vaughan, 2006) y los mejores aceptores son partículas dHDL cargadas con fosfolípidos (Wang y col., 2001; Smith y col., 2004). Por otro lado la rHDL de $96 \AA$ sin colesterol, mostró la mayor capacidad de unión a membranas en células RAW 264.7, inducidas con H-Col y AR, la conformación que adopta la apoA-I en estas partículas y la mayor expresión del transportador ABCG1, podrían ser los responsables de tal afinidad. 
Por otro lado las células RAW 264.7 pretratadas con Br-AMPc unieron apoA-I y rHDL con mayor eficacia en comparación con las pretratadas con $\mathrm{H}-\mathrm{Col}$ y $\mathrm{AR}$. Al mismo tiempo el eflujo de colesterol mediado por apoA-I y rHDL fue tres veces mayor que el producido con $\mathrm{H}$-Col y $\mathrm{AR}$. Este incremento en la capacidad de unión y eflujo de colesterol, por parte de la apoA-I, como así también de las partículas, puede ser debido a la activación e inducción de la expresión del transportador ABCA1 (Suzuki y col., 2004; Cavelier y col., 2006) por parte del Br-AMPc, que activa la vía de señalización AMPc-PKA en células RAW 264.7 (See y col., 2002; Oram y col., 2000), además de incrementar la fluidez de la membrana, gracias a su actividad flipasa de fosfolípidos y colesterol (Oram y Vaughan, 2006). El AMPc activa la proteína quinasa $A$ (PKA), que fosforila el transportador ABCA1, aumentando su afinidad por apoAI, además de estimular la sobreexpresión del transportador (Suzuki y col., 2004; Cavelier y col., 2006). Por otro lado la apoA-I estabiliza al ABCA1 evitando su degradación por calpaína (Lund-Katz y col., 2010). Como mencionamos el ABCA1 incrementa la fluidez de la membrana, generando un empaquetamiento más débil, debido a su actividad flipasa de fosfolípidos y colesterol. El aumento de la fluidez posibilita la generación de una curvatura o protrusión en la membrana plasmática que permite la lipidación inicial de la apoA-I con la consiguiente formación de HDL discoidales (Vedhachalam y col., 2007; Lin y col.; 2000). El transportador ABCA1 trabaja sinérgicamente con el transportador ABCG1 (Gelissen y col., 2006; Vaughan y Oram, 2006), siendo que la apoA-I como las $\mathrm{dHDL}$ pequeñas a medida que se cargan principalmente de fosfolípidos, pierden afinidad por el transportador ABCA1 y aumentan su afinidad por el transportador ABCG1, que media el eflujo principalmente de colesterol. El incremento en la fluidez de la membrana activaría al transportador $A B C G 1$ que necesita al igual que el $A B C A 1$ un empaquetamiento de membrana más débil para poder interactuar y transferir principalmente colesterol a las dHDL. Por otro lado la disminución de la temperatura de incubación de 37 a $4^{\circ} \mathrm{C}$ en ambos pretratamientos con $\mathrm{H}-\mathrm{Col}$ y $A R, y$ con Br-AMPc disminuyó la fluidez de la membrana y afectó la interacción de la apoA-I y de las rHDL. El aumento de fluidez de membrana incrementa la afinidad entre el transportador y la apoA-I (Nandi y col., 2009) y es necesario para la microsolubilización de lípidos. 


\subsubsection{Eflujo de colesterol}

A nivel del eflujo de colesterol en células CHO-K1, la apoA-I como las rHDL removieron significativamente colesterol. La apoA-I como la rHDL de $120 \AA$ sin col., mostraron el menor porcentaje de remoción en comparación con el resto de las partículas, esto puede ser debido a la necesidad inicial de la apoA-I, de lipidarse principalmente con fosfolípidos, vía el transportador ABCA1 (Wang y col., 2001).

En el caso de las dHDL a medida que crecen en tamaño por la captación de fosfolípidos y colesterol (Fielding y col., 2000), pierden afinidad por el transportador ABCA1, e incrementan su afinidad por el transportador ABCG1, ambos transportadores trabajan de manera coordinada. Cuando la partícula dHDL alcanza su máximo crecimiento, disminuye la afinidad por el transportador ABCG1 y se disocia de la membrana, volviéndose un buen sustrato de la enzima LCAT (Cavigiolio y col. 2008). La apoA-I adopta diferentes conformaciones en las $\mathrm{dHDL}$, lo que determina su afinidad por transportadores y receptores de membranas, como así también la efectividad en el eflujo de colesterol y fosfolípidos (Cavigiolio y col., 2008). Como se observó en células $\mathrm{CHO}-\mathrm{K} 1$ las rHDL de mayor tamaño (120 Å), mostraron el menor porcentaje de eflujo de colesterol al igual que las $\mathrm{rHDL}$ de $120 \AA$ sin colesterol en células RAW 264.7 estimuladas con Br-AMPc.

Por otro lado en células RAW 264.7 la apoA-I fue efectiva en la remoción de colesterol sólo en pretratamientos con Br-AMPc, dado que con $\mathrm{H}$-Col y AR la remoción de colesterol no fue significativa. Sin embargo la apoA-I como las rHDL, se unieron significativamente a membranas en ambos tratamientos. Probablemente la inducción con $\mathrm{H}-\mathrm{Col}$ y $\mathrm{AR}$, condujo a un aumento en la expresión de los transportadores involucrados en el eflujo de colesterol, pero este incremento solamente no fue suficiente en este tipo celular, para estimular el eflujo vía apoA-I, más allá del eflujo basal. En el pretratamiento con Br-AMPc se observó un incremento significativo en el eflujo de colesterol mediado por la apoA-I, esto puede ser debido a que el Br-AMPc conduce a la activación del 
ABCA1 vía señalización AMPc-PKA en células RAW 264.7, además de sobreexpresarlo (Suzuki y col., 2004; Cavelier y col., 2006).

En células $\mathrm{CHO}-\mathrm{K} 1$ las $\mathrm{rHDL}$ de 78 y $96 \AA$ sin colesterol mostraron la mayor eficacia en la remoción de colesterol, pero en células RAW 264.7 no se ha observado una gran influencia del tamaño y contenido de colesterol en la remoción de colesterol. Sin embargo en el pretratamiento con Br-AMPc se observó un incremento en la remoción de colesterol en los discos de $96 \AA$ sin colesterol en comparación con los discos con colesterol. Estas partículas son las más grandes conteniendo dos apo A-I por disco. Existe cierta controversia en la literatura con respecto a la remoción de colesterol por parte de las partículas rHDL de distinto tamaño. Algunos autores reportan que las partículas más pequeñas ( $78 \AA ̊$ Å) son las más activas (Jonas y col., 1994), otros reportan que las más grandes ( 120 ̊̊) son las más eficientes (Agnani y Marcel, 1993). Esta contradicción puede ser debida a los diferentes tipos de células utilizadas en los distintos estudios, a la diferencia de expresión de los transportadores y también podría reflejar distintas habilidades de las $\mathrm{rHDL}$ de acceder a regiones específicas de la membrana, dónde se encuentran los distintos transportadores que intervienen en el eflujo de colesterol.

\subsubsection{Distribución de radioactividad entre colesterol libre y esterificado}

En células CHO-K1 se observó que la apoA-I disminuyó significativamente la relación $\mathrm{CE} / \mathrm{col}$. y que las $\mathrm{rHDL}$ sin colesterol tendieron a disminuir la relación. Por otro lado en células RAW 264.7 se observó que la apoA-I y las rHDL $78 \AA$, no modificaron el radio $C E / c o l$. y las $\mathrm{rHDL}$ de mayor tamaño (96 y $120 \AA$ ) tendieron a incrementarlo, siendo significativo para las rHDL de $96 \AA$ con colesterol. Un comportamiento diferente se observó en las dos líneas celulares. Mientras que las rHDL sin colesterol incrementaron la esterificación de colesterol en células RAW 264.7, las mismas rHDL diminuyeron el colesterol esterificado en células $\mathrm{CHO}-\mathrm{K} 1$. Este comportamiento puede ser debido al metabolismo particular de cada tipo celular. Los macrófagos esta adaptado a almacenar grandes cantidades de ésteres de colesterol en lipids droplets y transformarse en células espumosas. Por otro lado Kiss y col., (2005) 
observaron que algunas líneas de macrófagos (J774) tienen un elevado radio $\mathrm{CE} / \mathrm{col}$. y este se correlaciona directamente con un elevado eflujo de colesterol.

\subsubsection{Eflujo de Fosfolípidos de colina}

En ambos tipos celulares se encontró que la apoA-I como la rHDL $78 \AA$ fueron buenos aceptores de fosfolípidos de colina, preferentemente de fosfatidilcolina. La efectividad de la apoA-I en este proceso puede deberse a la necesidad inicial de lipidarse con fosfolípidos y en menor medida con colesterol como se mencionó. Por otro lado las rHDL de mayor tamaño (96 y $120 \AA$ Å) sólo fueron eficaces en la remoción de fosfolípidos en células RAW 264.7, observándose un porcentaje de eflujo menor, en comparación con la apoA-l y rHDL de $78 \AA$. Las rHDL de 96 y $120 \AA$ interaccionan con el transportador ABCG1 (Faviari y col., 2009), que como función principal carga las dHDL con colesterol, pero también puede transferir en menor proporción fosfolípidos (Oram y Vaughan, 2006). Además se observó que las rHDL de 78 y $120 \AA$ fueron más eficaces en la remoción de fosfolípidos que la rHDL de $96 \AA$, este hecho puede deberse a que pueden alargar su tamaño admitiendo más fosfolípidos que las de $96 \AA$, que tienen una capacidad limitada de crecimiento debido a la cantidad de apoA-I por disco.

Por otro lado se observó en células RAW 264.7 una tendencia, las rHDL con colesterol removieron un mayor porcentaje de fosfolípidos de colina, en comparación con sus pares sin colesterol, esto puede ser debido, a que la presencia de colesterol en las partículas, facilitaría la microsolubilización de fosfolípidos en este tipo celular.

En ambos tipos celulares el fosfolípido de colina preferido por apoA-I y rHDL fue la fosfatidilcolina. Existe cierta controversia en la literatura en cuanto a la preferencia de fosfolípidos removidos por la apoA-I y rHDL. Según Kobayashi y col. (2006), los transportadores ABCA1 y ABCG1 transfieren una variedad de especies fosfolipídicas, dentro de los fosfolípidos de colina prefieren la fosfatidilcolina y esfingomielina respectivamente, dato que se correlaciona con los obtenidos a nivel de la apoA-I y rHDL de $78 \AA$, pero es contradictorio a nivel de las rHDL de mayor tamaño (96 y $120 \AA$ Å). En cambio Sano y col., (2007) 
demostraron que el transportador ABCG1 no sólo transfiere esfingomielina sino también fosfatidilcolina, dato que sí se correlaciona con los observados a nivel del eflujo de fosfatidilcolina mediado por las rHDL de 96 y $120 \AA$. 


\section{CAPÍTULO 5.}

VARIANTES DE APOA-I, $\triangle \mathrm{K} 107 \mathrm{Y} \triangle \mathrm{K} 226$ IMPLICANCIAS EN LA REMOCIÓN DE LÍPIDOS 


\section{CAPÍTULO 5. VARIANTES DE APOA-I, $\Delta \mathrm{K} 107 \quad \mathrm{Y} \quad \Delta \mathrm{K} 226$ IMPLICANCIAS EN LA REMOCIÓN DE LÍPIDOS}

\subsection{ANTECEDENTES DEL TEMA}

\subsubsection{El dominio central de apoA-I}

Como se mencionó en la Introducción general, la mayoría de las a-hélices anfipáticas de apoA-I presentan una distribución de cargas en su cara polar (tipo A) que es característica en todas las apolipoproteínas intercambiables. Esta distribución de cargas jugaría un rol importante en la interacción con superficies lipídicas (Mishra y col., 1994). Hay otras dos regiones, cada una un par de a-hélices anfipáticas (hélices 3-4 y 9-10) con una distribución de cargas particular (tipo Y) que sólo ocurren en apoA-I estando ausentes en las otras apolipoproteínas. Se postuló en este grupo de trabajo (Prieto y Garda, 2011), que al menos en la región central (par de hélices 3-4) esta distribución de cargas serviría para estabilizar a un ramillete intermolecular con la región homóloga de otra molécula de apoA-I, que se inserta profundamente en membranas fosfolipídicas (Corsico y col., 2001) contrariamente al resto de las hélices que interaccionan superficialmente con membranas. Este par de hélices parece funcionar como un dominio estructural y funcionalmente independiente, como se observó con un péptido sintético (Toledo y col, 2004). Mas aún, se postuló que este dominio estaría involucrado en la movilización de depósitos intracelulares de colesterol, y como lo indicaron experimentos con una mutante de deleción puntual en este dominio $(\Delta \mathrm{K} 107)$ y con una mutante en la que el par de hélices 3-4 fue intercambiado con el 9-10, para esta función se necesitaría un registro correcto de la hélice que es alterado por la deleción, pero no una secuencia específica mientras se mantenga la distribución de cargas tipo Y (Gonzalez y col., 2008). 


\subsubsection{Homeostasis y toxicidad del colesterol}

La célula tiene diferentes maneras de distribuir, almacenar, procesar y liberar el colesterol intracelular, que puede provenir de fuentes endógenas como exógenas. Ha sido demostrado que el exceso de colesterol por encima de las concentraciones fisiológicas induce toxicidad celular (Warner y col., 1995). Entre los diferentes efectos tóxicos que puede producir el colesterol: se encuentran: la activación de vías de señalización apoptóticas, alteración de membranas (Tabas, 1997; Warner y col., 1995) y formación de cristales de colesterol, entre otros. A nivel de la activación de diferentes vías apoptóticas, en macrófagos cargados de colesterol libre, se mostraron evidencias de la liberación del citocromo c de la mitocondria y la activación de la caspasa-9, en adición a la activación de la vía apoptótica Fas (Tabas, 2002). Con respecto a la alteración de membranas, debido al incremento en la concentración de colesterol a nivel de la membrana, se produce un aumento en la rigidez de la misma, impidiendo el correcto funcionamiento de proteínas claves (Tabas,1997). Finalmente en relación a la formación de cristales de colesterol, en macrófagos sobrecargados, se observa la formación de cristales intracelulares, que pueden romper físicamente diferentes estructuras celulares (Kellner-Weibel y col., 1999).

Entre los mecanismos que utiliza la célula para evitar la acumulación de colesterol libre intracelular, se encuentran la activación de diferentes vías de eflujo celular (difusión pasiva, facilitada y transporte activo), el almacenamiento del colesterol como ésteres de colesterol en lipids droplets, por la actividad de la enzima acil-CoA: colesterol aciltransferasa (ACAT), la regulación fina de la síntesis de novo de colesterol, la producción de ácidos biliares y hormonas esteroideas en hepatocitos y células esteroidogénicas respectivamente. Estos son algunos de los mecanismos, mediante los cuales la célula evita la acumulación de colesterol libre citotóxico.

La enzima ACAT se localiza en el RE, es la encargada de esterificar el colesterol libre y almacenarlo en forma de ésteres de colesterol en lipids droplets (fig. 5-1). Esta finamente regulada por el colesterol y los oxiesteroles, los que funcionan como moduladores positivos de su actividad (Chang y col., 
2009). Dos isoformas de ACAT han sido identificadas, ACAT-1 y ACAT-2 cada una con diferentes patrones de expresión y funciones fisiológicas únicas. La ACAT-2 se expresa únicamente en enterocitos y hepatocitos y participa en el ensamblaje de lipoproteínas, mientras que ACAT-1 se expresa en casi todos los tipos celulares y es la forma principal en macrófagos y células esteroidogénicas (Akopian y Medh, 2006).

La ACAT juega un rol importante en la homeostasis del colesterol. ACAT-1 que se expresa en la mayoría de las células, distribuye el colesterol celular entre pooles de colesterol libre y esterificado y a nivel de enterocitos y hepatocitos ACAT-2 regula la producción de ésteres de colesterol para ser incorporados en lipoproteínas plasmáticas (Chang y col.,2009).

Por otro lado la acción de ACAT-1, es opuesta a la enzima colesterol ester hidrolasa (CEH), que mediante hidrólisis de los ésteres de colesterol, genera colesterol libre. El colesterol libre es la fuente preferida para el eflujo de colesterol, en presencia de aceptores extracelulares (Gosh, 2011).

Entre las $\mathrm{CEH}$, la enzima lipasa sensible a hormonas (HSL) es la candidata principal a cumplir esta función en macrófagos RAW 264.7 (Escary y col., 1998; Tazoe y col., 2008). La actividad de esta enzima se encuentra regulada hormonalmente, las hormonas glucagón, catecolaminas y adrenocorticotropa (ACTH) estimulan su actividad. Además se encuentra regulada positivamente por fosforilación, vía AMPc/PKA (Kraemer y Shen, 2002).

La PKA fosforila a HSL (fig. 5-1), de manera tal que se activa e hidroliza los ésteres de colesterol, produciendo colesterol libre, que rápidamente debe ser removido o reesterificado por ACAT-1. 


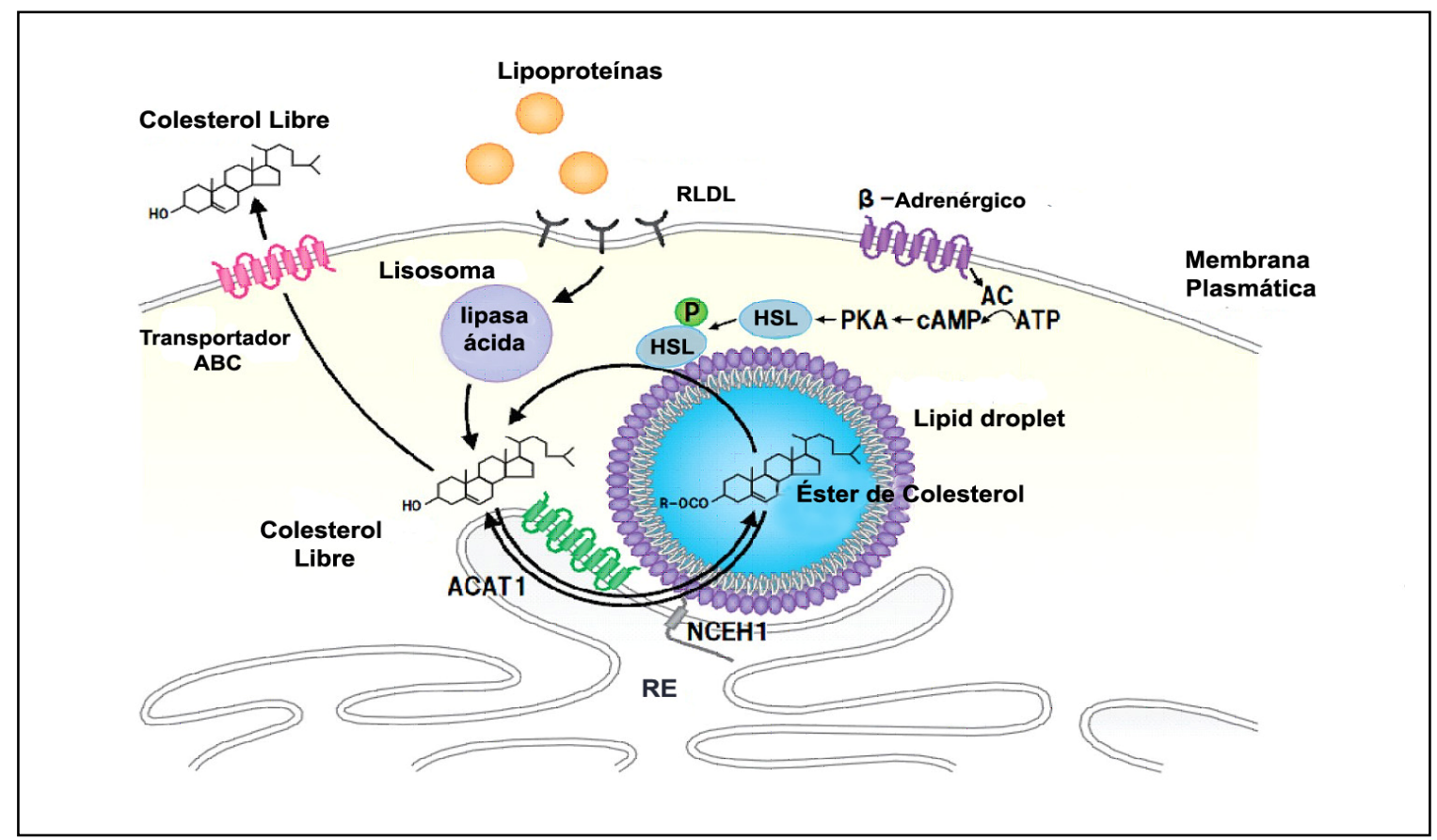

Figura. 5-1. Homeostasis del colesterol esterificado en macrófagos (Sekiya y col., 2010, con modificaciones). Las lipoproteínas son captadas por los receptores y direccionadas hacia los lisosomas, donde los CE son hidrolizados a colesterol libre (FC) y ácidos grasos por la lipasa ácida lisosomal (LAL). El exceso de FC es reesterificado por Acil-CoA: colesterol aciltransferasa 1 (ACAT-1) y almacenado en lipids droplets (LD) en el citoplasma. La acción de ACAT es opuesta a la hidrólisis de CE. Entre las principales lipasas que hidrolizan CE en macrófagos, se encuentran: la lipasa sensible a hormona (HSL) y la colesterol ester hidrolasa 1 (NCEH1). El FC resultante puede ser reesterificado por ACAT-1 o removido por aceptores extracelulares vía transportadores $\mathrm{ABC}$.

\subsubsection{Variantes naturales de la apoA-I}

Existen unas 61 variantes naturales de apoA-I. Aproximadamente la mitad, están asociadas a concentraciones bajas de c-HDL. La apoA-I Helsinky, variante natural de la apoA-I, afecta su región central presentando una deleción de lisina en la posición 107. Los pacientes portadores de esta mutación presentan un metabolismo anormal de HDL (Tilly-Kiesi y col., 1995), elevado catabolismo de apoA-I (Tilly-Kiesi y col., 1997) y baja estabilidad. Además se la relaciona con patologías como la amiloidosis (Amarzguioui y col., 1998) y enfermedad coronaria (Tilly-Kiesi y col., 1997).

Se ha postulado que el dominio central de la apoA-I esta involucrado en la activación de LCAT. En el caso de la apoA-I Helsinky, existen ciertas 
controversias en cuanto a la activación de LCAT. Según Philippe y Marcel, (2000), la $\Delta$ K107 no es efectiva en la activación. Esta como otras mutaciones puede tener efectos en la conformación del dominio central de la apoA-I e indirectamente afectar la habilidad de la apoA-I de activar LCAT. Por otro lado, Huang (2001), demostró que la $\Delta \mathrm{K} 107$ presenta la misma capacidad de la apoA-I salvaje para activar LCAT y remover colesterol de fibroblastos y que presenta baja afinidad de unión a lípidos. Con respecto a la conformación de la $\Delta K 107$, según Ramella y col., (2012) la región $\mathrm{N}$-terminal de la $\Delta \mathrm{K} 107$, presenta diferencias conformacionales sutiles con respecto a la apoA-I salvaje.

A nivel de la homeostasis del colesterol, datos de nuestro laboratorio, han demostrado que la $\Delta \mathrm{K} 107$ es incapaz de movilizar el colesterol sintetizado de novo y aquel disponible a ser esterificado por ACAT, en células CHO-K1 (Gonzalez y col.2008).

\subsection{OBJETIVOS PARTICULARES}

Con el fin de determinar si el domino central de la apoA-I se encuentra involucrado en el eflujo de lípidos, homeostasis del colesterol y efecto citoprotector en células RAW 264.7 se realizaron los siguientes experimentos: 1) construcción, expresión y purificación de mutantes de deleción de lisina en la posición $107(\Delta \mathrm{K} 107)$ y $226(\Delta \mathrm{K} 226)$ de la apoA-I recombinante (apoA-Ir), que se espera tengan cambiado el registro de las hélices, 2) análisis del comportamiento de las variantes a nivel del eflujo de colesterol y fosfolípidos de colina, 3) determinación de la presencia de ACAT-1 4) toxicidad del colesterol y 5) efecto citoprotector de apoA-I y variantes. 


\subsection{RESULTADOS}

\subsubsection{Obtención y expresión de $\Delta \mathrm{K} 107$ y $\Delta \mathrm{K} 226$}

La fig. 5-2 ilustra la posición de las mutaciones $\Delta \mathrm{K} 107$ y $\Delta \mathrm{K} 226$ en las hélices 4 y 10 , respectivamente.

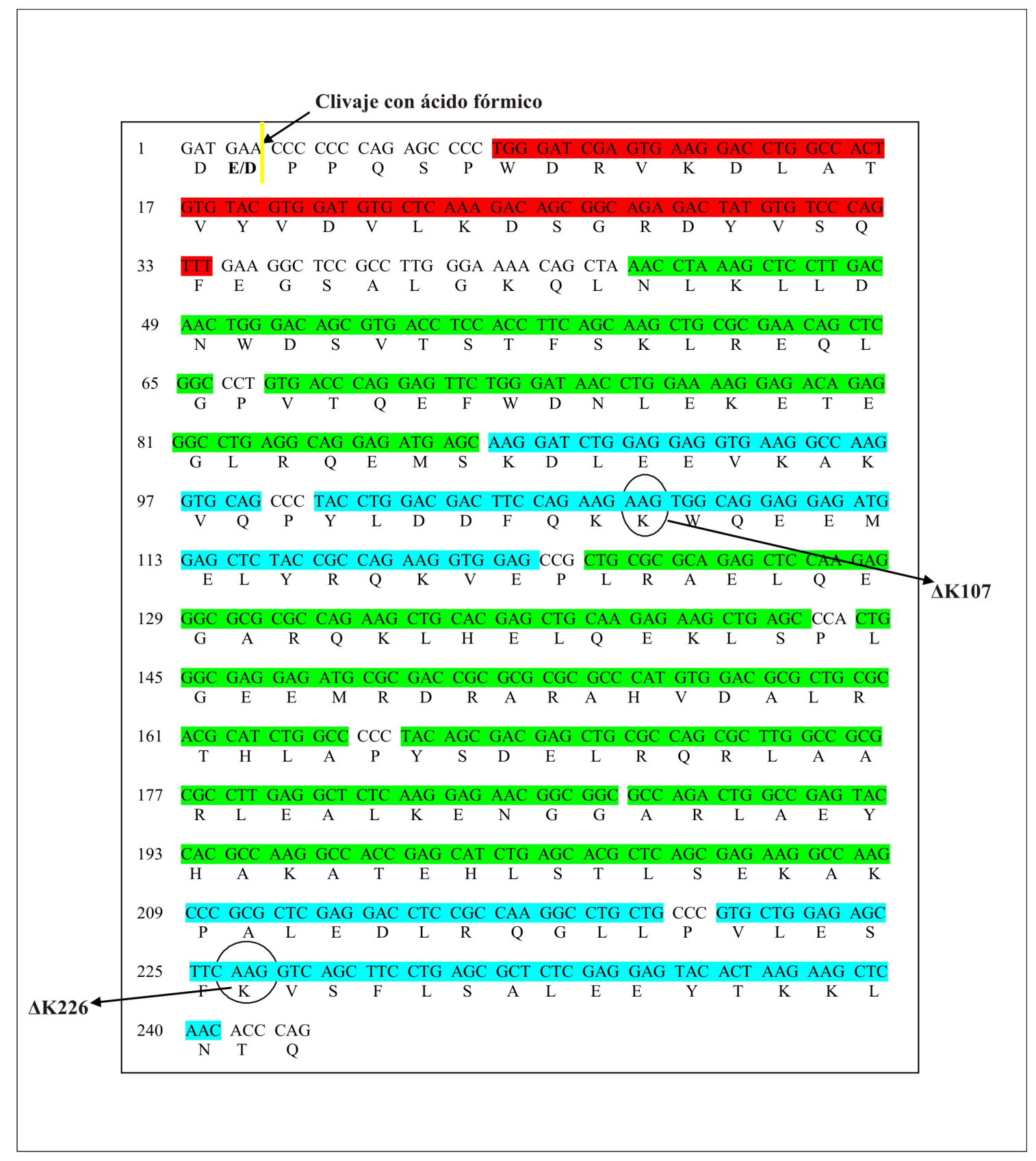

Figura 5-2. Secuencia de apoA-I humana madura. Se muestran en color las hélices predichas (Segrest y col., 1992) en rojo hélices $G^{*}$, en turquesa hélices $Y$ en verde hélice $A$, así como el punto de clivaje con ácido fórmico, en amarillo, generado por el cambio de $E$ por $D$ en el segundo residuo. Así, las secuencias finales de estas proteínas comienzan a partir del tercer residuo. 
Las mutaciones fueron realizadas como se indicó en Materiales y Métodos. Una vez que se obtuvieron las secuencias correctas, con las deleciones de lisina en la posición 107 o 226 de la apoA-Ir, se transformaron bacterias E.coli BL21, cepa especial para la expresión de proteínas recombinantes (sección 3.4.3, materiales y métodos). Luego se realizó un ensayo de expresión a pequeña escala, mediante la inducción de las bacterias con IPTG, a fin de probar la expresión de las proteínas recombinantes $\Delta \mathrm{K} 107$ y $\Delta \mathrm{K} 226$. La colonia que tuvo un mejor nivel de expresión (fig. 5-3) fue seleccionada para hacer un stock de glicerol que se guardó a -80 C.

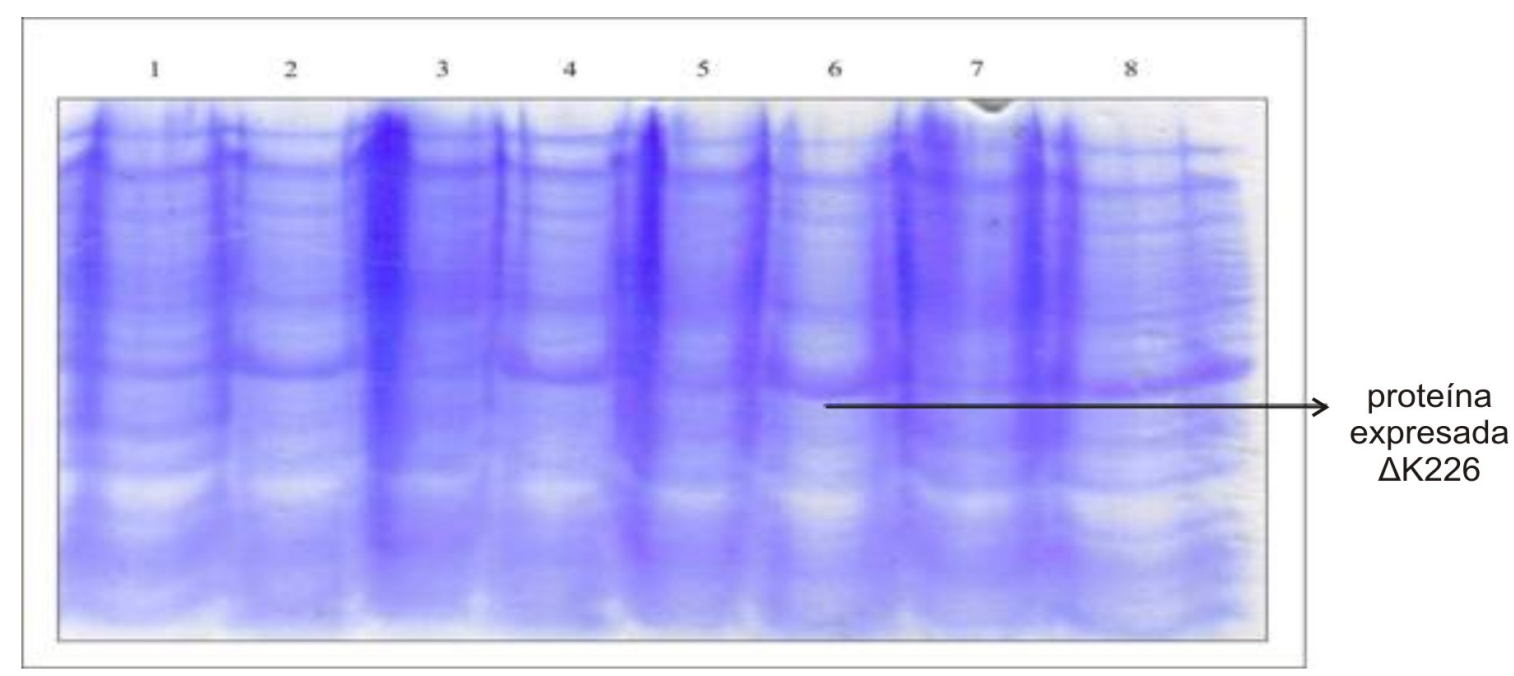

Figura 5-3. Análisis SDS-Page en gel al 16\%. Expresión a pequeña escala, bajo la inducción con IPTG de la proteína recombinante $\Delta$ K226 en bacterias BL21 E.coli. En calles 1, 3,5 y 7 se observa la expresión proteica de bacterias que no fueron inducidas con IPTG. En las calles 2, 4, 6 y 8 las que sí fueron inducidas con IPTG.

\subsubsection{Purificación apoA-Ir, $\Delta \mathrm{K} 107$ y $\Delta \mathrm{K} 226$}

Después de la expresión en bacterias BL21, la apoA-I fusionada a la cola de polihistidina, se purificó por columna de níquel (sección 3.4.4, materiales y métodos) y se clivó con ácido fórmico al $45 \%$ (sección 3.4.5, materiales y métodos). En la figura 5-4 se muestra la última etapa de purificación de la apoA-Ir. Se observa que la preparación final (calle 4), presenta un muy buen grado de pureza. En la fracción eluída con 0,5 M imidazol (calle 5), queda el resto de la proteína no clivada y el péptido polihistidina. 
En la figura 5-5 se muestra el análisis de la etapa final de purificación de las mutantes $\Delta \mathrm{K} 107$ y $\Delta \mathrm{K} 226$, luego de clivar las proteínas fusionadas a la cola de polihistidina. Las fracciones 5 y 9 corresponden a las preparaciones finales que muestran un muy buen grado de pureza.

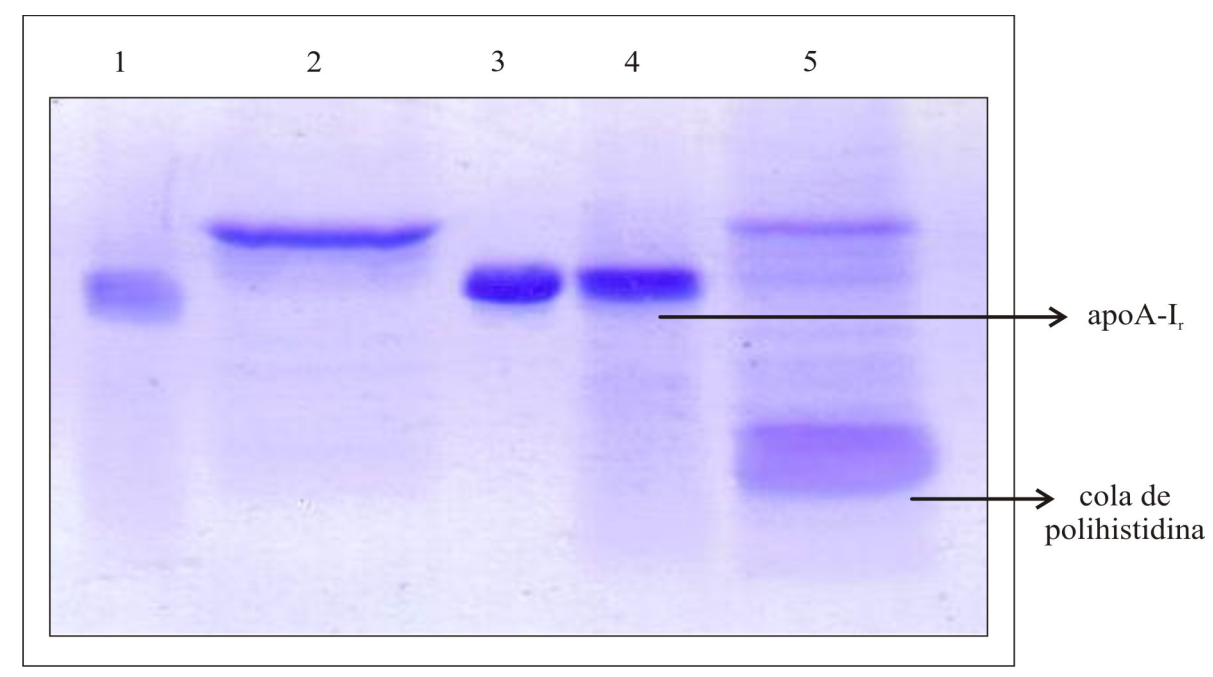

Figura 5-4. Análisis SDS PAGE en gel al 16\% de las fracciones eluídas al cargar una columna de níquel con una preparación de apoA-I recombinante clivada con ácido fórmico 45\%. Las calles 2 y 3 corresponden a estándares de apoA-I con y sin cola de polihistidina respectivamente. La calle 1 es la fracción no retenida. Las calles 4 y 5 son las fracciones eluídas con $10 \mathrm{mM}$ y $0,5 \mathrm{M}$ de imidazol respectivamente.

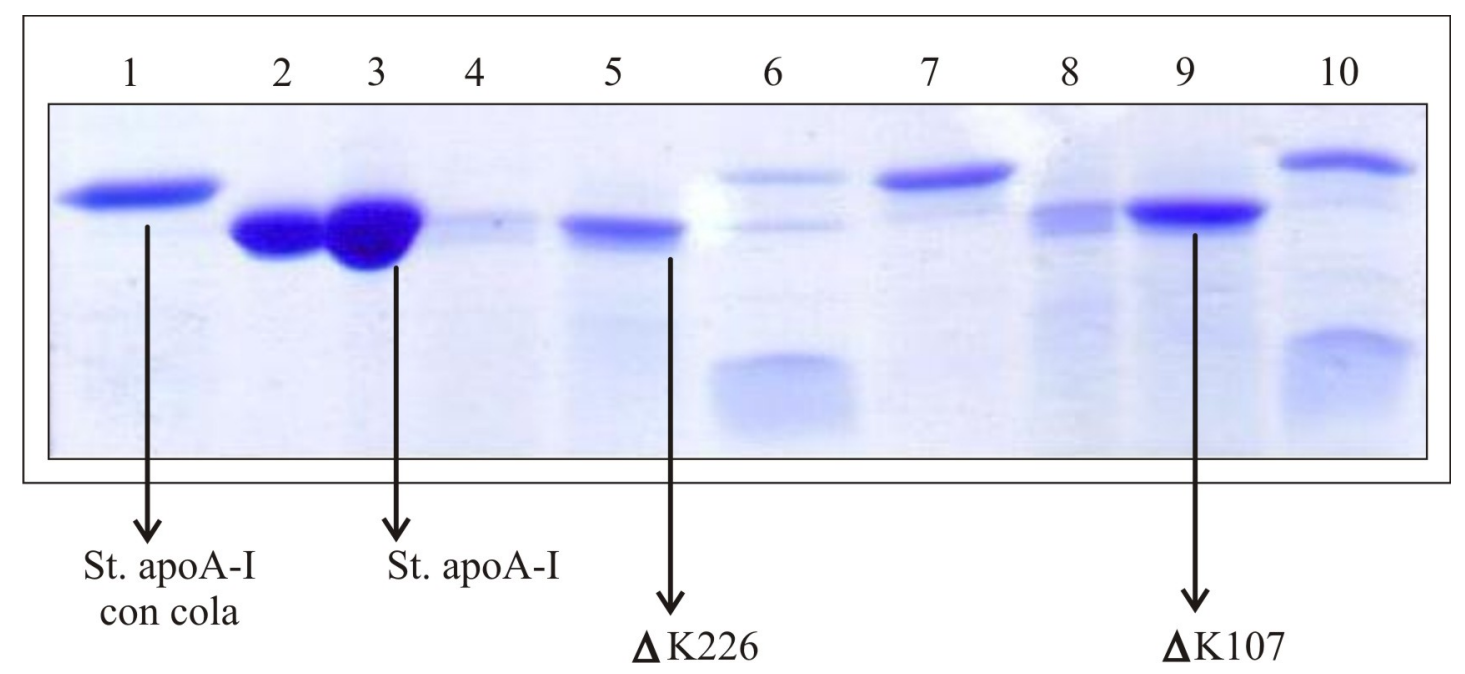

Figura 5-5. Análisis por SDS-PAGE en gel al $16 \%$ de las fracciones eluídas de una columna con níquel inmovilizado de las preparaciones de $\Delta \mathrm{K} 226$ (calles 4 a 6) y de $\Delta \mathrm{K} 107$ (calles 8 a 10), luego del clivaje con ácido fórmico $45 \%$. Las calles 1 y 7 corresponden a estándares de apoA-I con cola de polihistidina y las calles 2 y 3 a apoA-I sin cola de polihistidina. Las calles 4 y 8 corresponden a las fracciones no retenidas por la columna. Las calles 5 y 9 son las fracciones eluídas con $10 \mathrm{mM}$ imidazol, y las calles 6 y 10 las fracciones eluídas con 0,5 M imidazol. 


\subsubsection{Eflujo de lípidos en células RAW 264.7}

\subsubsection{Eflujo de colesterol mediado por apoA-Ir, $\Delta \mathrm{K} 107$ y $\Delta \mathrm{K} 226$}

La apoA-Ir como así también las mutantes de deleción de lisina, $\Delta \mathrm{K} 107$ y $\Delta K 226$, a la concentración testeadas de $30 \mu \mathrm{g} / \mathrm{ml}$, remocionaron activamente colesterol con respecto al control. Las mutantes de deleción de lisina como la apoA-Ir se comportaron de manera similar a nivel del eflujo de colesterol.

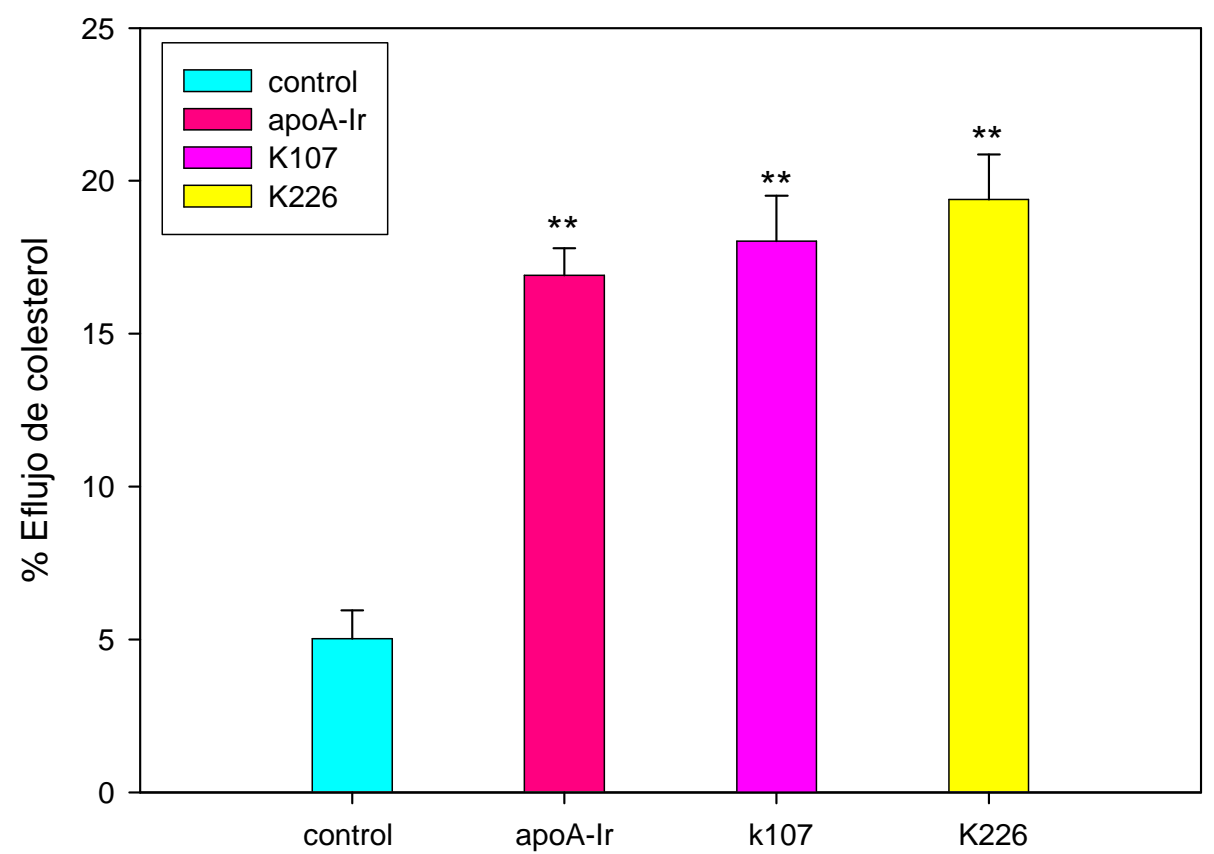

Figura 5-6. Eflujo de colesterol en células RAW 264.7 mediado por apoA-Ir y variantes: $\Delta \mathrm{K} 107$ y $\Delta \mathrm{K} 226$. Las células fueron cargadas con colesterol $50 \mu \mathrm{g} / \mathrm{ml}$ y $0,05 \mu \mathrm{Ci}\left[{ }^{14} \mathrm{C}\right]$ colesterol en medio DMEM sin SFB, complementado con $2 \mathrm{mg} / \mathrm{ml}$ de BSA, durante 24 h. Luego se agregó una solución de equilibrado, con 1 $\mathrm{mg} / \mathrm{ml}$ de BSA y $0,5 \mathrm{mM} \mathrm{Br}-\mathrm{AMPc}$ y se incubó $8 \mathrm{~h}$. Finalizada la incubación se agregaron las proteínas a una concentración de $30 \mu \mathrm{g} / \mathrm{ml}$ en medio DMEM sin SFB, con 0,5 mM Br-AMPc durante $12 \mathrm{~h}$. Los datos estadísticos se analizaron mediante test t de Student, con niveles de significancia en comparación con el control de: * $\mathrm{P}<0,05 ;{ }^{* *} \mathrm{P}<0,01 \mathrm{y}{ }^{* * *} \mathrm{P}<0,001$. 


\subsubsection{Eflujo de fosfolípidos mediado por apoA-Ir, $\Delta \mathrm{K} 107$ y $\Delta \mathrm{K} 226$}

La apoA-Ir como así también la $\Delta K 226$, removieron activamente fosfolípidos de colina. La $\Delta K 226$, fue más efectiva que la apoA-Ir en el eflujo de fosfolípidos. Por otro lado la mutante $\Delta \mathrm{K} 107$, no se mostró efectiva en este proceso en tratamientos de $12 \mathrm{~h}$.

El eflujo de fosfolípidos de colina parecería ser dependiente de la correcta distribución de cargas a nivel de la región central, siendo que la deleción en la posición 107 afectó este proceso. Por otro lado la $\Delta$ K226 mostró la mayor eficacia a nivel del eflujo de fosfolípidos de colina, la deleción incrementó la función de la apoA-I a nivel de este proceso.

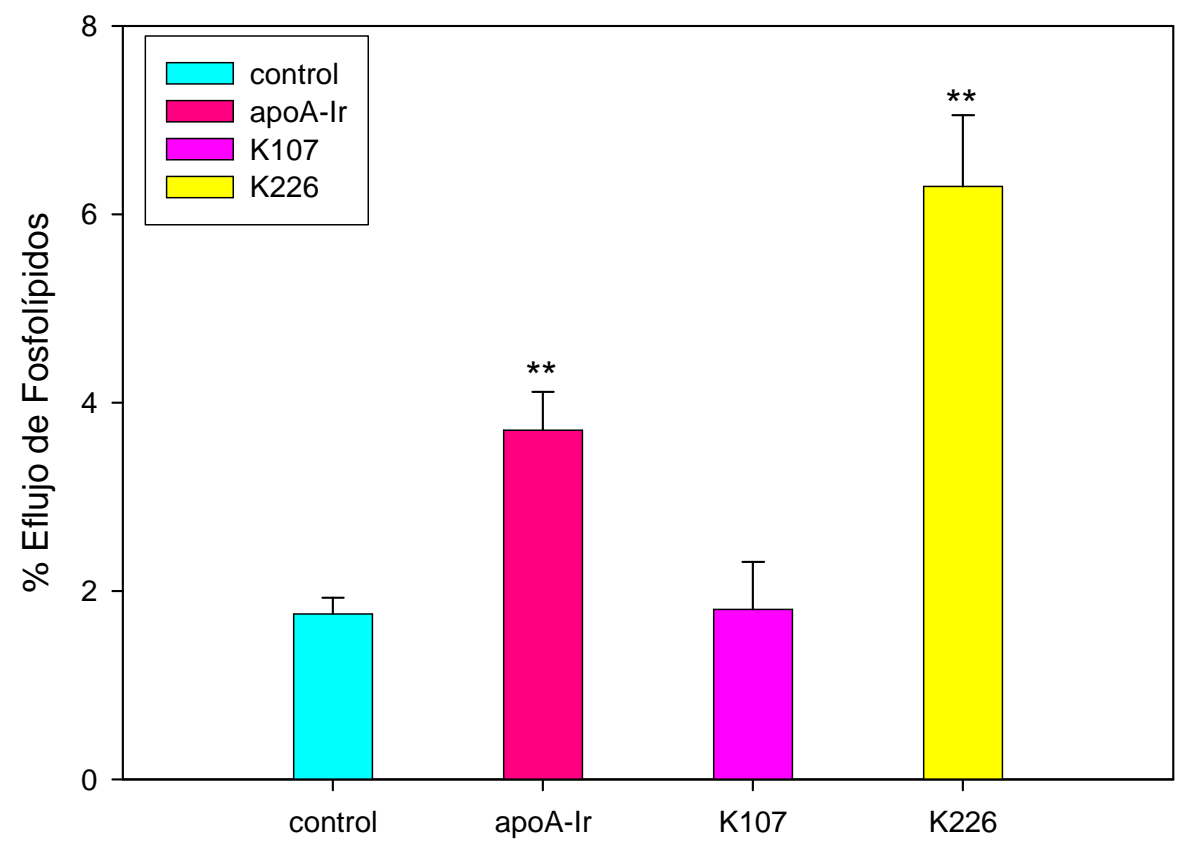

Figura 5-7. Eflujo de fosfolípidos de colina en células RAW 264.7 mediado por apoA-Ir y mutantes $\triangle \mathrm{K} 107$ y $\triangle K 226$. Las células fueron cargadas con $50 \mathrm{ug} / \mathrm{ml}$ y $0,5 \mu \mathrm{Ci}$ de $\left[{ }^{14} \mathrm{C}\right]$ colina en medio DMEM sin SFB suplementado con $2 \mathrm{mg} / \mathrm{ml}$ de BSA durante $24 \mathrm{~h}$. Luego se agregó una solución de equilibrado, con 1 $\mathrm{mg} / \mathrm{ml}$ de BSA y 0,5 mM Br-AMPc, y se incubó $8 \mathrm{~h}$. Finaliza la incubación se agregó apoA-lr, $\triangle \mathrm{K} 107$ y $\triangle \mathrm{K} 226$ a una concentración de $30 \mathrm{ug} / \mathrm{ml}$ en medio DMEM sin suero con 0,5 mM Br-AMPc y se incubó durante $12 \mathrm{~h}$. Los análisis estadísticos se realizaron mediante el test $\mathrm{t}$ de Student, con niveles de significancia con respecto del control de: ${ }^{*} P<0,05 ;{ }^{* *} P<0,01 y^{* \star *} P<0,001$. 


\subsubsection{Nivel celular de ACAT-1}

Con el fin de determinar si la apoA-I y las variantes $\triangle \mathrm{K} 107$ y $\triangle \mathrm{K} 226$ eran capaces de modificar los niveles de ACAT-1 en células RAW 264.7, estas fueron incubadas con las proteínas como se indicó en Materiales y Métodos, determinando los niveles de ACAT-1 por western blotting.

Como se observa en la fig. $5-8$, sólo la mutante $\Delta \mathrm{K} 107$ incrementó la concentración de ACTA-1 en macrófagos RAW 264.7, activados con Br-AMPc.

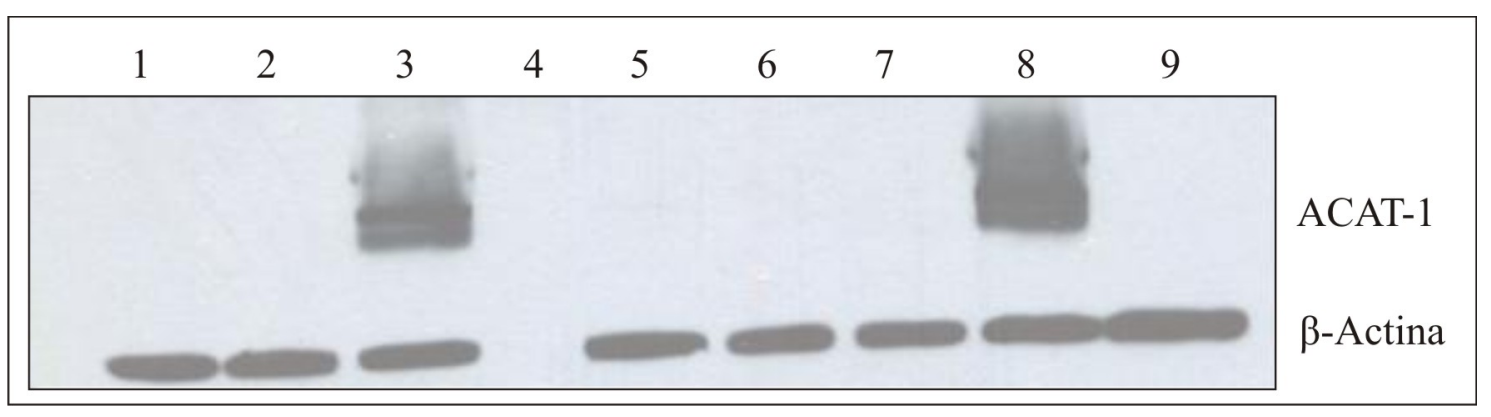

Figura 5-8. Determinación de la presencia de ACAT-1 por western blot. Las células RAW 264.7 fueron cargadas con $50 \mu \mathrm{g} / \mathrm{ml}$ de colesterol y activadas con Br-AMPc. Luego se incubó con apoA-Ir, $\Delta \mathrm{K} 107$ y $\triangle$ K226. Los niveles celulares de ACAT-1 y $\beta$-actina se estimaron por western blotting con anticuerpos específicos revelando por ECL. Las Calles 1 y 5 se corresponden con el control sin proteínas, las calles 2 y 6 se corresponden a apoA-Ir, las calles 3 y 8 a $\Delta K 107$, la calle 4 al St. Rainbow, 5 y 9 a $\Delta K 226$.

Por otro lado, se analizó la distribución de radioactividad entre las fracciones de colesterol y ésteres de colesterol luego de administrar colesterol radiomarcado con $\left[{ }^{14} \mathrm{C}\right]$. Para ello se extrajeron los lípidos de las monocapas celulares mediante la técnica de Bligh \& Dyer (Bligh, 1959), se separaron por TLC y se cuantificó mediante el Image Quant del Storm. Se observó que la distribución de radioactividad entre las fracciones de colesterol libre y ésteres de colesterol, no se modificó con respecto al control por el tratamiento con apoA-Ir o las mutantes $\Delta \mathrm{K} 107$ y $\Delta \mathrm{K} 226$. Así, a pesar de que el nivel celular de la proteína ACAT-1 es incrementado por el tratamiento con $\Delta \mathrm{K} 107$, esto no resulta en una mayor esterificación del colesterol agregado exógenamente. 


\subsubsection{Cuantificación ARNm ACAT-1}

A partir de los resultados obtenidos se decidió cuantificar la cantidad de ARNm ACAT-1, mediante qRT-PCR, con el objetivo de determinar si el aumento en la concentración proteica de ACAT-1 se debe al aumento de su ARNm.

Se observó que el gen de ACAT-1 no se sobreexpresaba en ninguna de las condiciones testeadas, en relación al control de $\beta$-actina (fig. 5-9). Por lo tanto el tratamiento con $\triangle \mathrm{K} 107$ incrementó la concentración proteica de ACAT-1, pero no estimuló la sobreexpresión del gen y tampoco se observó un aumento en la concentración intracelular de ésteres de colesterol.

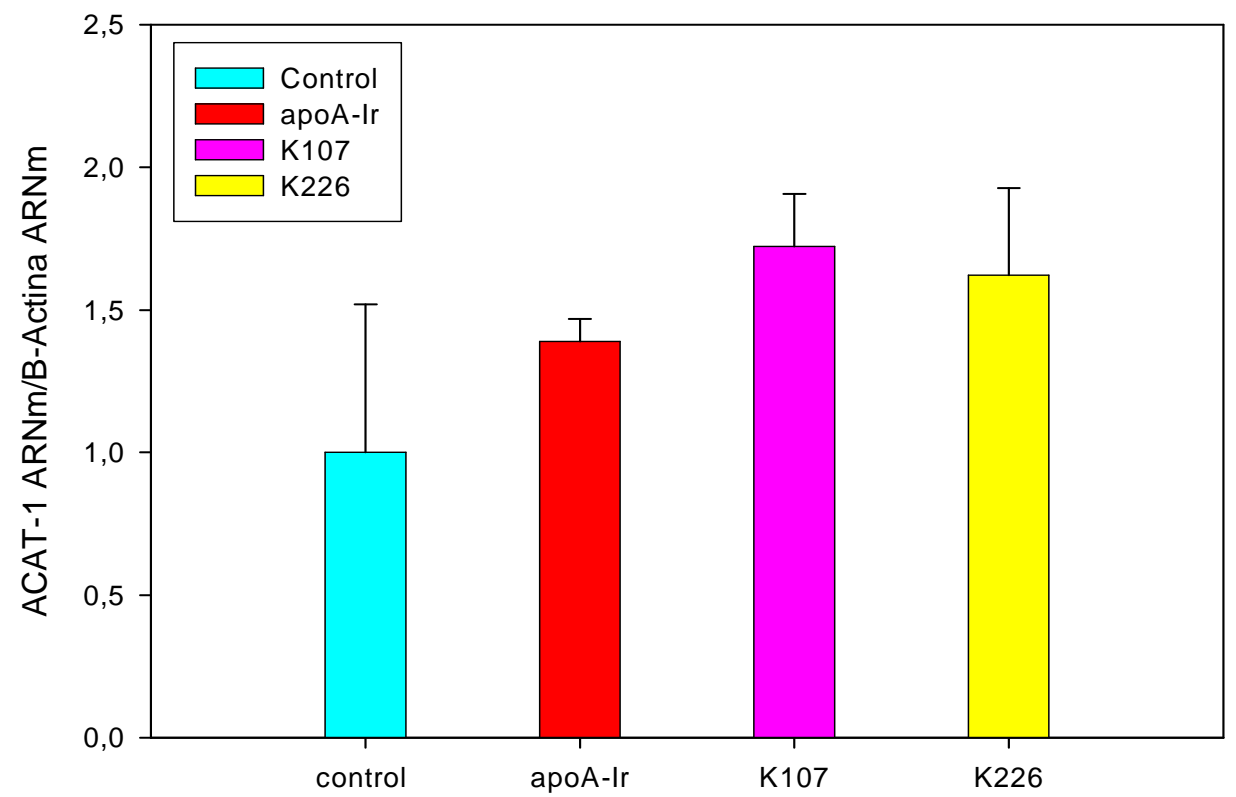

Figura 5-9 Expresión relativa de ACAT-1 en células RAW 264.7. Se utilizó el método de $\triangle \mathrm{CT}$ para determinar los cambios en los niveles de expresión y se normalizó en relación a la expresión de $\beta$-Actina. Las células fueron cargadas con $50 \mu \mathrm{g} / \mathrm{ml}$ de colesterol y tratadas con apoA-Ir, $\Delta \mathrm{K} 107$ y $\Delta \mathrm{K} 226$.

\subsubsection{Citotoxicidad del colesterol}

Para determinar el efecto de la carga de colesterol en células RAW 264.7, se realizó un ensayo de viabilidad celular por medio del test del MTT. Este ensayo mide la funcionalidad mitocondrial, dado que la enzima succinato deshidrogenada reduce el MTT a formazán (insoluble y de color púrpura). 
Como se observa en la fig. 5-10 se vio una tendencia de disminuir la funcionalidad mitocondrial a concentraciones crecientes de colesterol, siendo significativa a $60 \mu \mathrm{g} / \mathrm{ml}$ en células RAW 264.7 .

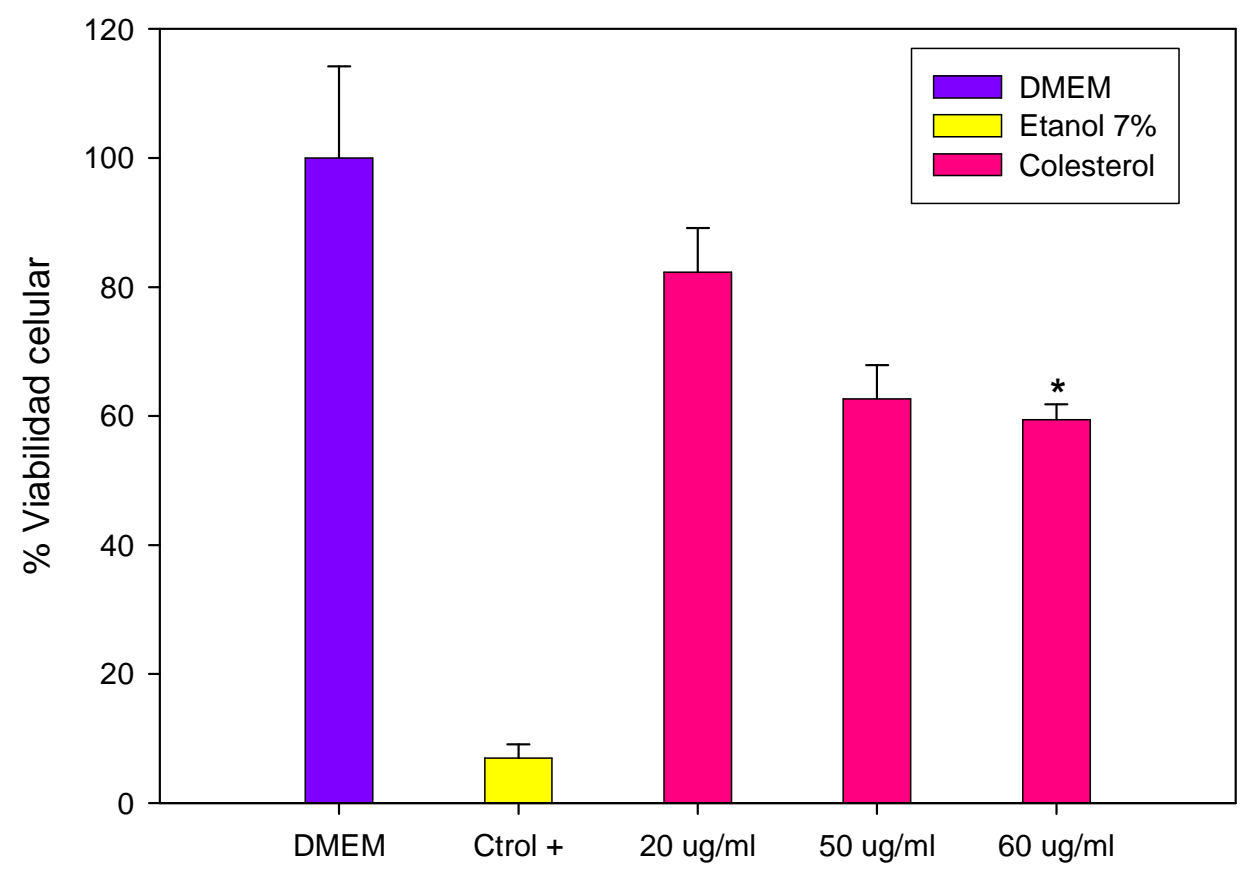

Figura 5-10. Ensayo de citotoxicidad del colesterol en células RAW 264.7, mediante el test de MTT. Las células fueron incubadas con 20,50 y $60 \mu \mathrm{g} / \mathrm{ml}$ de colesterol en DMEM durante $24 \mathrm{~h}$. Se utilizó como control positivo de muerte celular: etanol al $7 \%$ y control negativo células en DMEM solamente. Los análisis estadísticos se realizaron mediante el test $t$ de Student con niveles de significancia con respecto al control de: ${ }^{*} \mathrm{P}<0,05 ;{ }^{* *} \mathrm{P}<0,01 \mathrm{y}{ }^{* * *} \mathrm{P}<0,001$.

\subsubsection{Efecto citoprotector apoA-I y variantes}

Para determinar si la apoA-I y sus variantes, $\Delta \mathrm{K} 107$ y $\Delta \mathrm{K} 226$, tienen algún efecto protector a nivel celular, se realizó el ensayo del MTT, con diferentes concentraciones de colesterol, en ausencia y presencia de las proteínas. Las concentraciones de colesterol utilizadas fueron: $0,50,70,90,110,130,200$, 300 y $500 \mu \mathrm{g} / \mathrm{ml}$ en medio DMEM, combinadas con $30 \mu \mathrm{g} / \mathrm{ml}$ de apoA-I o variantes $\Delta$ K107 y $\Delta$ K226. Por comparación, también se ensayó la apoA-I purificada de suero humano (apoA-Is). 


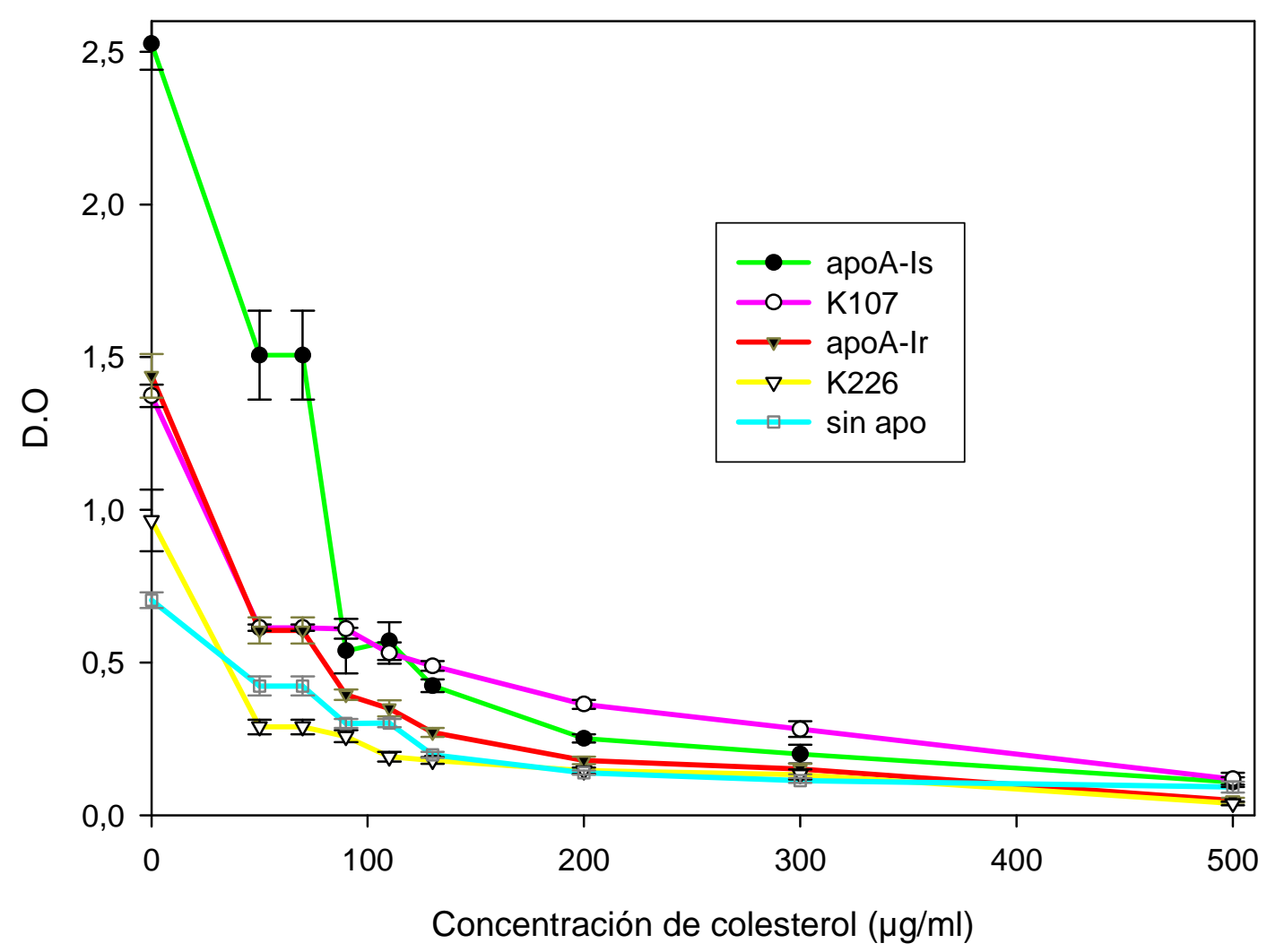

Figura 5-11. Efecto citoprotector apoA-I y variantes en células RAW 264.7. Mediante el test del MTT con diferentes concentraciones de colesterol en presencia o ausencia de las proteínas se determinó el efecto citoprotector de apoA-I y variantes $\Delta \mathrm{K} 107$ y $\Delta \mathrm{K} 226$ en DMEM. Los análisis estadísticos se realizaron mediante ANOVA. Los niveles de significancia respecto del control sin apoA-I ni variantes fueron los siguientes:

\begin{tabular}{|l|c|c|c|c|c|c|c|c|}
\hline \multirow{2}{*}{ Proteína } & \multicolumn{7}{|c|}{ Concentración de colesterol $(\mu \mathrm{g} / \mathrm{ml})$} \\
\cline { 2 - 9 } & 0 & 50 & 70 & 90 & 110 & 130 & 200 & 300 \\
\hline apoA-Is & $\mathrm{P}<0,001$ & $\mathrm{P}<0,001$ & $\mathrm{P}<0,001$ & $\mathrm{P}<0,001$ & $\mathrm{P}<0,001$ & $\mathrm{P}<0,001$ & $\mathrm{P}<0,001$ & $\mathrm{P}<0,05$ \\
\hline apoA-Ir & $\mathrm{P}<0,001$ & n.s & n.s & n.s & n.s & $\mathrm{P}<0,01$ & $\mathrm{n} . \mathrm{s}$ & n.s \\
\hline$\Delta \mathrm{K} 107$ & $\mathrm{P}<0,001$ & n.s & n.s & $\mathrm{P}<0,001$ & $\mathrm{P}<0,001$ & $\mathrm{P}<0,001$ & $\mathrm{P}<0,001$ & $\mathrm{P}<0,001$ \\
\hline$\Delta \mathrm{K} 226$ & n.s & n.s & n.s & n.s & n.s & n.s & n.s & n.s \\
\hline
\end{tabular}

n.s = no significativo

Se observó que la apoA-Is como la apoA-Ir y $\Delta \mathrm{K} 107$ mostraron un poder protector mitocondrial, sin una carga externa de colesterol. Siendo la apoA-Is la más efectiva en este proceso, seguido por $\Delta \mathrm{K} 107$ y apoA-Ir que se comportaron de manera parecida. Contrariamente, la variante $\Delta K 226$, no mostró este efecto y se comportó como sí en el medio no hubiera apoA-I ni variantes. 
Cuando las células fueron sometidas a una carga externa de colesterol se observó que a concentraciones bajas de colesterol (50 y $70 \mu \mathrm{g} / \mathrm{ml}$ ), sólo la apoA-ls mostró eficaz capacidad protectora mitocondrial y se comportó de manera diferente al resto de las proteínas. A concentraciones medias (90 y 110 $\mu \mathrm{g} / \mathrm{ml}$ ) la $\Delta \mathrm{K} 107$ mostró capacidad protectora mitocondrial y se comportó de la misma manera que la apoA-ls. A altas concentraciones de colesterol (130, 200 y $300 \mu \mathrm{g} / \mathrm{ml}$ ), la $\Delta \mathrm{K} 107 \mathrm{como}$ la apoA-ls se mostraron eficaces en este proceso. Siendo la $\Delta$ K107 la que presentó mayor eficacia a 130 y $200 \mu \mathrm{g} / \mathrm{ml}$ de colesterol, a $300 \mu \mathrm{g} / \mathrm{ml}$ de colesterol se comportaron de la misma manera. Por otro lado la apoA-Ir mostró capacidad protectora a $130 \mu \mathrm{g} / \mathrm{ml}$ de colesterol. Con respecto a la $\Delta \mathrm{K} 226$ no presentó capacidad protectora mitocondrial frente a una carga externa de colesterol en las condiciones ensayadas.

Finalmente a una concentración muy alta de colesterol $(500 \mu \mathrm{g} / \mathrm{ml})$, ninguna de las proteínas testeadas, fueron eficaces en promover la protección mitocondrial en células RAW 264.7.

\subsection{DISCUSIÓN}

\subsubsection{Eflujo de lípidos en células RAW 264.7}

\subsubsection{Eflujo de colesterol}

La apoA-Ir como las mutantes de deleción de lisina, $\Delta \mathrm{K} 107$ y $\Delta \mathrm{K} 226$, se comportaron de manera similar a nivel del eflujo de colesterol de células RAW 264.7. Para el caso de $\Delta \mathrm{K} 107$, esto concuerda con lo previamente observado en células CHO-K1 (Gonzalez y col., 2008).

Es de prever que una deleción en una hélice anfipática genere un cambio en su registro de manera que a ambos lados de la deleción se produzca una rotación de unos $100^{\circ}$ en su orientación (Garda, 2007). Este cambio en la orientación de las caras hidrofílica e hidrofóbica puede alterar las propiedades de interactuar con superficies lipídicas o con otras proteínas como diferentes receptores celulares. 
Así, la modificación del registro de la hélice 4 en la región central como la hélice 10 en el extremo $C$, no alteran el comportamiento de la apoA-I a nivel del eflujo de colesterol de células RAW 264.7 o CHO-K1.

\subsubsection{Eflujo de fosfolípidos de colina}

La apoA-Ir como la $\Delta \mathrm{K} 226$, mutante de deleción de lisina de la región Cterminal, fueron eficaces en el eflujo de fosfolípidos de colina, además la $\Delta$ K226 mostró la mayor eficacia en este proceso (en tratamientos a $12 \mathrm{~h}$ ). Un cambio en el registro de la hélice a nivel de la región C-terminal de la apoA-I, incrementó el eflujo de fosfolípidos, podría considerarse a la $\Delta K 226$ como una mutación con ganancia de función a nivel de la remoción de fosfolípidos de colina.

Contrariamente la $\Delta \mathrm{K} 107$ se mostró inefectiva en el eflujo de fosfolípidos de colina, en tratamientos a $12 \mathrm{~h}$, indicando que el cambio en el registro de la hélice $Y$ central afectó la funcionalidad de la apoA-I. Sin embargo, en experimentos más reciente de este laboratorio en los que las células fueron radiomarcadas con $\left[{ }^{14} \mathrm{C}\right]$ fosforilcolina y el eflujo de fosfolípidos de colina se midió a $18 \mathrm{~h}$, se observó que en estas condiciones la mutante $\Delta \mathrm{K} 107$ fue tan activa como apoA-Ir (Toledo y col., 2013).

\subsubsection{Nivel celular de ACAT-1}

El tratamiento de células RAW 264.7 con la mutante $\Delta \mathrm{K} 107$ resultó en un dramático incremento en el nivel celular de ACAT-1. Esto fue observado para diferentes niveles de carga de colesterol vehiculizado con albúmina o con LDL, y parece ser independiente del tipo celular ya que también fue detectado con macrófagos THP1 y células CHO-K1 (Toledo y col, 2013).

Ya que la activación de ACAT-1 es un evento clave en la transformación de macrófagos en células espumosas, es posible que este aumento en el nivel de ACAT-1 pueda estar relacionado con el incrementado riesgo aterogénico de los pacientes portadores de $\Delta \mathrm{K} 107$. Sin embargo, a pesar del dramático 
incremento en el nivel de la proteína ACAT-1, no se detectó una acumulación de ésteres de colesterol ni una redistribución del colesterol radiomarcado entre las fracciones de colesterol libre y esterificado. Sólo un pequeño incremento en la relación de radioactividad entre las fracciones de ésteres de colesterol y colesterol fue detectado en células RAW 264.7 cargadas con colesterol vía LDL (Toledo y col, 2013), pero estos pequeños cambios no se correlacionaron con el dramático incremento en el nivel celular de ACAT-1 detectado por western blotting. Así, es probable que ACAT-1 se acumule en la célula en un estado inactivo o en un compartimiento celular inaccesible al colesterol agregado exógenamente. Otra posibilidad es la activación paralela de una enzima que hidrolice los ésteres de colesterol como la lipasa sensible a hormonas (HSL). Mediciones en ausencia de análogos de AMPc, que activan a HSL, sólo resultaron en un leve incremento en la esterificación de colesterol radiomarcado exógeno, mientras que el nivel de ACAT fue incrementado más de 10 veces (Toledo y col, 2013).

También se demostró aquí que el nivel del ARNm de ACAT-1 no es modificado por $\triangle$ K107. Así, la acumulación de la proteína ACAT-1 sólo puede ser explicada por un aumento en la velocidad de la traducción (con niveles constantes de ARNm) o por una disminución en la velocidad de degradación de la proteína.

Al respecto, se reportó que la fracción $\mathrm{HDL}_{2}$ inhibe la actividad de ACAT en macrófagos como consecuencia de su traslocación a un compartimiento inactivo. $\mathrm{HDL}_{2}$ incrementa la velocidad de síntesis y recambio de ACAT sin modificar el nivel total de la enzima (Li y Pownall, 2000). Los autores proponen que $\mathrm{HDL}_{2}$ se comporta como un iniciador de una vía de transducción de señales que conduce a la traslocación e inhibición de ACAT. Es probable que esta acción de $\mathrm{HDL}_{2}$ se deba a su apolipoproteína mayoritaria apoA-I. En ese caso, la deleción de la lisina 107 podría resultar en una señalización alterada que conduce a la acumulación de ACAT observada en este trabajo. 


\subsubsection{Efecto protector apoA-I y variantes $\Delta \mathrm{K} 107$ y $\Delta \mathrm{K} 226$}

La apoA-Is como la apoA-Ir y la variante $\Delta \mathrm{K} 107$ mostraron capacidad protectora mitocondrial frente a concentraciones tóxicas de colesterol. Curiosamente cuando las células no fueron cargadas con colesterol se observó que la apoA-Is como la apoA-Ir y $\Delta \mathrm{K} 107$ mostraron un poder protector celular. Ramella y col. (2012), demostraron que tanto la apoA-Ir como la $\Delta \mathrm{K} 107$ en células RAW 264.7 no inducían la producción de especies reactivas de oxígeno (ROS), no así otras variantes de la apoA-I, como la apoA-I lowa (Gly26Arg). Quizás debido a este efecto, se observa un nivel de protección incluso sin una carga de colesterol externa.

Por otro lado a nivel de la apoA-ls se observó una mayor capacidad protectora a concentraciones bajas de colesterol (50 y $70 \mu \mathrm{g} / \mathrm{ml}$ ), siendo que a concentraciones medianas (90 y $110 \mu \mathrm{g} / \mathrm{ml}$ ) y altas $(130$ y $200 \mu \mathrm{g} / \mathrm{ml}$ ) la $\Delta \mathrm{K} 107$ fue la de mayor eficacia. Esto podría ser debido a un cambio conformacional en la $\Delta$ K107 que favorezca alguna de las vías de distribución y almacenamiento de colesterol. Podría ser que el incremento en la concentración de ACAT-1, observado con la $\Delta \mathrm{K} 107$, favorezca este efecto y se acentué aún más con cargas importantes de colesterol. De modo tal que la presencia de ACAT-1 entre otros factores podría favorecer el efecto citoprotector de $\Delta \mathrm{K} 107$.

Finalmente la $\Delta \mathrm{K} 226$ no mostró un efecto citoprotector. Podría suponerse que la región C-terminal de la apoA-I estaría relacionada con el efecto protector de la apoA-I, dado que tanto la apoA-Isérica como la recombinante fueron eficaces en este proceso. 


\section{CAPÍTULO 6.}

\section{CONCLUSIONES}




\section{CAPÍTULO.6 CONCLUSIONES GENERALES}

\subsection{COMPORTAMIENTO DE LAS dHDL DE DIFERENTE TAMAÑO Y COMPOSICIÓN}

- En células $\mathrm{CHO}-\mathrm{K} 1$ pre-tratadas con $\mathrm{H}-\mathrm{Col}+\mathrm{AR}$, apoA-I y las $\mathrm{rHDL}$ se unen con similar eficiencia a la membrana celular, con relativa independencia del tamaño y contenido de colesterol de las partículas lipoproteicas.

- En el caso de las células RAW 264.7, la eficiencia de unión a la membrana celular es dependiente de la temperatura y del pre-tratamiento de las células ( $\mathrm{H}-\mathrm{Col}+\mathrm{AR}$ o $\mathrm{Br}-\mathrm{AMPC})$. La eficiencia de unión es mayor a $37^{\circ} \mathrm{C}$ que a $4^{\circ} \mathrm{C}$; y el pre-tratamiento con $\mathrm{Br}-\mathrm{AMPc}$ resultó en una mayor unión de apoA-I y las $\mathrm{rHDL}$ a la membrana celular en comparación con el pre-tratamiento con $\mathrm{H}-\mathrm{Col}+\mathrm{AR}$.

- El pre-tratamiento de células RAW 264.7 con Br-AMPc también resultó en un mayor eflujo de colesterol celular mediado por apoA-I y rHDL en comparación con el pre-tratamiento con $\mathrm{H}-\mathrm{Col}+\mathrm{AR}$.

- Salvo en los casos del pre-tratamiento de células RAW 264.7 con Br-AMPc que incrementó tanto la unión a la membrana como el eflujo de colesterol, y la presencia de colesterol en las rHDL que en la mayoría de los casos produjo una disminución en ambos fenómenos, no existe una absoluta correlación entre la unión a la membrana celular con el eflujo de colesterol.

- En células $\mathrm{CHO}-\mathrm{K} 1$, el tratamiento con apoA-I y algunas $\mathrm{rHDL}$ como las de $120 \AA$ A sin colesterol resultó en una disminución de la relación de radioactividad en la fracción de ésteres de colesterol respecto a colesterol, indicando una menor esterificación del colesterol. En el caso de las células RAW 264.7, en cambio, esta relación no fue modificada por apoA-I y la mayoría de las rHDL, e incluso fue incrementada para el caso de las de $96 \AA$ con colesterol. 
- Sólo apoA-I y las rHDL de menor tamaño (78 Å) sin colesterol promovieron eflujo de fosfatidilcolina de células CHO-K1. Salvo las rHDL de $96 \AA \sin$ colesterol, las otras rHDL promovieron el eflujo de estos fosfolípidos de células RAW 264.7 pre-tratadas con Br-AMPc, aunque con menos eficiencia que la apoA-I no lipidada. La presencia de colesterol en las rHDL tendió a incrementar el eflujo de fosfatidilcolina. El eflujo de estos fosfolípidos tendió a disminuir la relación de radioactividad en $\mathrm{PC} / \mathrm{SM}$.

\subsection{VARIANTES DE APOA-I, $\triangle K 107$ y $\triangle$ K226. IMPLICANCIAS EN LA REMOCIÓN DE LÍPIDOS}

- Las variantes $\Delta \mathrm{K} 107$ y $\Delta \mathrm{K} 226$ fueron tan activas como la apoA-lr para promover eflujo de colesterol de macrófagos RAW 264.7 pre-tratados con $\mathrm{Br}$ AMPc.

- La variante $\Delta \mathrm{K} 226$ presentó una mayor eficiencia que apoA-Ir para promover el eflujo de fosfolípidos de colina de estos macrófagos. En cambio, la deleción en $\Delta$ K107 produjo una disminución en la eficiencia de remoción de fosfolípidos de colina en las condiciones probadas.

- El tratamiento de las células RAW 264.7 con la mutante $\Delta K 107$ resultó en un dramático incremento en el contenido celular de la proteína ACAT-1. Esto no fue acompañado por un incremento del correspondiente ARNm, indicando que podría deberse a una incrementada velocidad de traducción o a una deficiente degradación de la proteína.

- El dramático incremento en el contenido celular de ACAT-1 producido por $\Delta$ K107 tampoco fue acompañado por una mayor esterificación de colesterol radiomarcado agregado exógenamente.

- Esto sugiere que ACAT-1 podría acumularse en una forma inactiva, o en un compartimento que es inaccesible al colesterol agregado exógenamente. 
- Futuros estudios son necesarios para determinar si este efecto de $\Delta \mathrm{K} 107$ es o nó relevante para el incrementado riesgo aterogénico que presentan los pacientes portadores de esta mutación.

- La mutante $\Delta \mathrm{K} 226$ contrariamente a la $\Delta \mathrm{K} 107$ y apoA-I salvaje, no mostró un efecto citoprotector frente a concentraciones citotóxicas de colesterol en las condiciones ensayadas. 


\section{CAPÍTULO 7. \\ BIBLIOGRAFÍA}




\section{CAPÍTULO.7 BIBLIOGRAFÍA}

Adorni, M. P., F. Zimetti, J. T. Billheimer, N. Wang, D. J. Rader, M. C. Phillips and G. H. Rothblat (2007). "The roles of different pathways in the release of cholesterol from macrophages." J Lipid Res 48(11): 2453-62.

Akopian, D. and J. D. Medh (2006). "Genetics and molecular biology: macrophage ACAT depletion - mechanisms of atherogenesis." Curr Opin Lipidol 17(1): 85-8.

Amarzguioui, M., G. Mucchiano, B. Haggqvist, P. Westermark, A. Kavlie, K. Sletten and $H$. Prydz (1998). "Extensive intimal apolipoprotein A1-derived amyloid deposits in a patient with an apolipoprotein A1 mutation." Biochem Biophys Res Commun 242(3): 534-9.

Barter, P., A. M. Gotto, J. C. LaRosa, J. Maroni, M. Szarek, S. M. Grundy, J. J. Kastelein, V. Bittner and J. C. Fruchart (2007). "HDL cholesterol, very low levels of LDL cholesterol, and cardiovascular events." N Engl J Med 357(13): 1301-10.

Barter, P., J. Kastelein, A. Nunn and R. Hobbs (2003). "High density lipoproteins (HDLs) and atherosclerosis; the unanswered questions." Atherosclerosis 168(2): 195-211.

Bligh, E. G. and W. J. Dyer (1959). "A rapid method of total lipid extraction and purification." Can J Biochem Physiol 37(8): 911-7.

Bojanovski, D., R. E. Gregg, G. Ghiselli, E. J. Schaefer, J. A. Light and H. B. Brewer, Jr. (1985). "Human apolipoprotein A-I isoprotein metabolism: proapoA-I conversion to mature apoA-I." J Lipid Res 26(2): 185-93.

Brown, M. S., Y. K. Ho and J. L. Goldstein (1980). "The cholesteryl ester cycle in macrophage foam cells. Continual hydrolysis and re-esterification of cytoplasmic cholesteryl esters." J Biol Chem 255(19): 9344-52. 
Cavelier, C., I. Lorenzi, L. Rohrer and A. von Eckardstein (2006). "Lipid efflux by the ATP-binding cassette transporters ABCA1 and ABCG1." Biochim Biophys Acta 1761(7): 655-66.

Cavigiolio, G., B. Shao, E. G. Geier, G. Ren, J. W. Heinecke and M. N. Oda (2008). "The interplay between size, morphology, stability, and functionality of high-density lipoprotein subclasses." Biochemistry 47(16): 4770-9.

Chang, T. Y., B. L. Li, C. C. Chang and Y. Urano (2009). "Acyl-coenzyme A:cholesterol acyltransferases." Am J Physiol Endocrinol Metab 297(1): E1-9.

Chang, T. Y., C. C. Chang and D. Cheng (1997). "Acyl-coenzyme A:cholesterol acyltransferase." Annu Rev Biochem 66: 613-38.

Chawla, A., W. A. Boisvert, C. H. Lee, B. A. Laffitte, Y. Barak, S. B. Joseph, D. Liao, L. Nagy, P. A. Edwards, L. K. Curtiss, R. M. Evans and P. Tontonoz (2001). "A PPAR gamma-LXR-ABCA1 pathway in macrophages is involved in cholesterol efflux and atherogenesis." Mol Cell 7(1): 161-71.

Chidlow, J. H., Jr. and W. C. Sessa (2010). "Caveolae, caveolins, and cavins: complex control of cellular signalling and inflammation." Cardiovasc Res 86(2): 219-25.

Chomczynski, P. and N. Sacchi (1987). "Single-step method of RNA isolation by acid guanidinium thiocyanate-phenol-chloroform extraction." Anal Biochem 162(1): 156-9.

Clunn, G. F., P. S. Sever and A. D. Hughes (2010). "Calcium channel regulation in vascular smooth muscle cells: synergistic effects of statins and calcium channel blockers." Int J Cardiol 139(1): 2-6.

Connelly, M. A. and D. L. Williams (2003). "SR-BI and cholesterol uptake into steroidogenic cells." Trends Endocrinol Metab 14(10): 467-72. 
Corsico, B., J. D. Toledo and H. A. Garda (2001). "Evidence for a central apolipoprotein A-I domain loosely bound to lipids in discoidal lipoproteins that is capable of penetrating the bilayer of phospholipid vesicles." J Biol Chem 276(20): 16978-85.

Crowther, J. R. (2009). "The ELISA guidebook." Methods in Molecular Biology 516.

de Beer, M. C., D. M. Durbin, L. Cai, A. Jonas, F. C. de Beer and D. R. van der Westhuyzen (2001). "Apolipoprotein A-I conformation markedly influences HDL interaction with scavenger receptor BI." J Lipid Res 42(2): 309-13.

Dean, M., Y. Hamon and G. Chimini (2001). "The human ATP-binding cassette (ABC) transporter superfamily." J Lipid Res 42(7): 1007-17.

Drobnik, W., H. Borsukova, A. Bottcher, A. Pfeiffer, G. Liebisch, G. J. Schutz, H. Schindler and G. Schmitz (2002). "Apo Al/ABCA1-dependent and HDL3mediated lipid efflux from compositionally distinct cholesterol-based microdomains." Traffic 3(4): 268-78.

Durbin, D. M. and A. Jonas (1997). "The effect of apolipoprotein A-II on the structure and function of apolipoprotein A-I in a homogeneous reconstituted high density lipoprotein particle." J Biol Chem 272(50): 31333-9.

Edidin, M. (1993). "Patches and fences: probing for plasma membrane domains." J Cell Sci Suppl 17: 165-9.

Escary, J. L., H. A. Choy, K. Reue and M. C. Schotz (1998). "Hormonesensitive lipase overexpression increases cholesteryl ester hydrolysis in macrophage foam cells." Arterioscler Thromb Vasc Biol 18(6): 991-8.

Favari, E., L. Calabresi, M. P. Adorni, W. Jessup, S. Simonelli, G. Franceschini and F. Bernini (2009). "Small discoidal pre-beta1 HDL particles are efficient 
acceptors of cell cholesterol via ABCA1 and ABCG1." Biochemistry 48(46): 11067-74.

Fielding, C. J. and P. E. Fielding (2003). "Relationship between cholesterol trafficking and signaling in rafts and caveolae." Biochim Biophys Acta 1610(2): 219-28.

Fielding, P. E., K. Nagao, H. Hakamata, G. Chimini and C. J. Fielding (2000). "A two-step mechanism for free cholesterol and phospholipid efflux from human vascular cells to apolipoprotein A-1." Biochemistry 39(46): 14113-20.

Fielding, P. E. and C. J. Fielding (1996). "Intracellular transport of low density lipoprotein derived free cholesterol begins at clathrin-coated pits and terminates at cell surface caveolae." Biochemistry 35(47): 14932-8.

Garda, H. A. (2007). "Structure-function relationships in human apolipoprotein A-I: role of a central heliz pair." Future Lipidol. 2(1), 95-104.

Gelissen, I. C., M. Harris, K. A. Rye, C. Quinn, A. J. Brown, M. Kockx, S. Cartland, M. Packianathan, L. Kritharides and W. Jessup (2006). "ABCA1 and ABCG1 synergize to mediate cholesterol export to apoA-I." Arterioscler Thromb Vasc Biol 26(3): 534-40.

Ghosh, S. (2011). "Macrophage cholesterol homeostasis and metabolic diseases: critical role of cholesteryl ester mobilization." Expert Rev Cardiovasc Ther 9(3): 329-40.

Gillotte, K. L., M. Zaiou, S. Lund-Katz, G. M. Anantharamaiah, P. Holvoet, A. Dhoest, M. N. Palgunachari, J. P. Segrest, K. H. Weisgraber, G. H. Rothblat and M. C. Phillips (1999). "Apolipoprotein-mediated plasma membrane microsolubilization. Role of lipid affinity and membrane penetration in the efflux of cellular cholesterol and phospholipid." J Biol Chem 274(4): 2021-8. 
Gonzalez, M. C., J. D. Toledo, M. A. Tricerri and H. A. Garda (2008). "The central type $\mathrm{Y}$ amphipathic alpha-helices of apolipoprotein $\mathrm{Al}$ are involved in the mobilization of intracellular cholesterol depots." Arch Biochem Biophys 473(1): 34-41.

Gordon, J. I., H. F. Sims, S. R. Lentz, C. Edelstein, A. M. Scanu and A. W. Strauss (1983). "Proteolytic processing of human preproapolipoprotein A-I. A proposed defect in the conversion of pro A-I to A-I in Tangier's disease." J Biol Chem 258(6): 4037-44.

Gordon, T., W. P. Castelli, M. C. Hjortland, W. B. Kannel and T. R. Dawber (1977). "High density lipoprotein as a protective factor against coronary heart disease. The Framingham Study." Am J Med 62(5): 707-14.

Gu, X., B. Trigatti, S. Xu, S. Acton, J. Babitt and M. Krieger (1998). "The efficient cellular uptake of high density lipoprotein lipids via scavenger receptor class $B$ type I requires not only receptor-mediated surface binding but also receptor-specific lipid transfer mediated by its extracellular domain." J Biol Chem 273(41): 26338-48.

Haidar, B., M. Denis, M. Marcil, L. Krimbou and J. Genest, Jr. (2004). "Apolipoprotein A-I activates cellular cAMP signaling through the ABCA1 transporter." J Biol Chem 279(11): 9963-9.

Hanahan, D. (1983). "Studies on transformation of Escherichia coli with plasmids." J Mol Biol 166(4): 557-80.

Hao, M., S. X. Lin, O. J. Karylowski, D. Wustner, T. E. McGraw and F. R. Maxfield (2002). "Vesicular and non-vesicular sterol transport in living cells. The endocytic recycling compartment is a major sterol storage organelle." J Biol Chem 277(1): 609-17.

Helgason, C. D. y. c. (2005). "Basic Cell Culture Protocols." Methods In Molecular Biology." Volume 290. 
Hua, X., C. Yokoyama, J. Wu, M. R. Briggs, M. S. Brown, J. L. Goldstein and X. Wang (1993). "SREBP-2, a second basic-helix-loop-helix-leucine zipper protein that stimulates transcription by binding to a sterol regulatory element." Proc Natl Acad Sci U S A 90(24): 11603-7.

Huang, W., A. Matsunaga, W. Li, H. Han, A. Hoang, M. Kugi, T. Koga, D. Sviridov, N. Fidge and J. Sasaki (2001). "Recombinant proapoA-I(Lys107del) shows impaired lipid binding associated with reduced binding to plasma high density lipoprotein." Atherosclerosis 159(1): 85-91.

Ikonen, E. (2008). "Cellular cholesterol trafficking and compartmentalization." Nat Rev Mol Cell Biol 9(2): 125-38.

Ikonen, E. (2001). "Roles of lipid rafts in membrane transport." Curr Opin Cell Biol 13(4): 470-7.

Ji, A., J. M. Meyer, L. Cai, A. Akinmusire, M. C. de Beer, N. R. Webb and D. R. van der Westhuyzen (2011). "Scavenger receptor SR-BI in macrophage lipid metabolism." Atherosclerosis 217(1): 106-12.

Jonas, A. (1986). "Reconstitution of high-density lipoproteins." Methods Enzymol 128: 553-82.

Kellner-Weibel, G., P. G. Yancey, W. G. Jerome, T. Walser, R. P. Mason, M. C. Phillips and G. H. Rothblat (1999). "Crystallization of free cholesterol in model macrophage foam cells." Arterioscler Thromb Vasc Biol 19(8): 1891-8.

Khera, A. V. and D. J. Rader (2010). "Future therapeutic directions in reverse cholesterol transport." Curr Atheroscler Rep 12(1): 73-81.

Kiss, R. S., J. Maric and Y. L. Marcel (2005). "Lipid efflux in human and mouse macrophagic cells: evidence for differential regulation of phospholipid and cholesterol efflux." J Lipid Res 46(9): 1877-87. 
Kobayashi, A., Y. Takanezawa, T. Hirata, Y. Shimizu, K. Misasa, N. Kioka, H. Arai, K. Ueda and M. Matsuo (2006). "Efflux of sphingomyelin, cholesterol, and phosphatidylcholine by ABCG1." J Lipid Res 47(8): 1791-802.

Kontush, A. and M. J. Chapman (2006). "Antiatherogenic small, dense HDL-guardian angel of the arterial wall?" Nat Clin Pract Cardiovasc Med 3(3): 14453.

Kraemer, F. B. and W. J. Shen (2002). "Hormone-sensitive lipase: control of intracellular tri-(di-)acylglycerol and cholesteryl ester hydrolysis." J Lipid Res 43(10): 1585-94.

Laemmli, U. K. (1970). "Cleavage of structural proteins during the assembly of the head of bacteriophage T4." Nature 227(5259): 680-5.

Landry, Y. D., M. Denis, S. Nandi, S. Bell, A. M. Vaughan and X. Zha (2006). "ATP-binding cassette transporter A1 expression disrupts raft membrane microdomains through its ATPase-related functions." J Biol Chem 281(47): 36091-101.

Lange, Y., J. Ye, M. Rigney and T. L. Steck (1999). "Regulation of endoplasmic reticulum cholesterol by plasma membrane cholesterol." J Lipid Res 40(12): 2264-70.

Li, L. and H. J. Pownall (2000). "Regulation of acyl-coenzyme A:cholesterol acyltransferase (ACAT) synthesis, degradation, and translocation by highdensity lipoprotein(2) at a low concentration." Arterioscler Thromb Vasc Biol 20(12): 2636-42.

Lin, G. and J. F. Oram (2000). "Apolipoprotein binding to protruding membrane domains during removal of excess cellular cholesterol." Atherosclerosis 149(2): 359-70. 
Liscum, L. and N. J. Munn (1999). "Intracellular cholesterol transport." Biochim Biophys Acta 1438(1): 19-37.

Lorenzi, I., A. von Eckardstein, C. Cavelier, S. Radosavljevic and L. Rohrer (2008). "Apolipoprotein A-I but not high-density lipoproteins are internalised by RAW macrophages: roles of ATP-binding cassette transporter A1 and scavenger receptor BI." J Mol Med (Berl) 86(2): 171-83.

Lowry, O. H., N. J. Rosebrough, A. L. Farr and R. J. Randall (1951). "Protein measurement with the Folin phenol reagent." J Biol Chem 193(1): 265-75.

Lund-Katz, S. and M. C. Phillips (2010). "High density lipoprotein structurefunction and role in reverse cholesterol transport." Subcell Biochem 51: 183227.

Lusa, S., S. Heino and E. Ikonen (2003). "Differential mobilization of newly synthesized cholesterol and biosynthetic sterol precursors from cells." J Biol Chem 278(22): 19844-51.

Marcel, P. G. F. a. Y. L. (2000). "Apolipoprotein A-I: structure-function relationships." J Lipid Res 41: 853-872.

Matz, C. E. and A. Jonas (1982). "Micellar complexes of human apolipoprotein A-I with phosphatidylcholines and cholesterol prepared from cholate-lipid dispersions." J Biol Chem 257(8): 4535-40.

Maxfield, F. R. and I. Tabas (2005). "Role of cholesterol and lipid organization in disease." Nature 438(7068): 612-21.

Maxfield, F. R. and D. Wustner (2002). "Intracellular cholesterol transport." J Clin Invest 110(7): 891-8.

Mendez, A. J., G. Lin, D. P. Wade, R. M. Lawn and J. F. Oram (2001). "Membrane lipid domains distinct from cholesterol/sphingomyelin-rich rafts are 
involved in the ABCA1-mediated lipid secretory pathway." J Biol Chem 276(5): 3158-66.

Mishra, V. K., M. N. Palgunachari, J. P. Segrest and G. M. Anantharamaiah (1994). "Interactions of synthetic peptide analogs of the class A amphipathic helix with lipids. Evidence for the snorkel hypothesis." J Biol Chem 269(10): 7185-91.

Mobius, W., E. van Donselaar, Y. Ohno-Iwashita, Y. Shimada, H. F. Heijnen, J. W. Slot and H. J. Geuze (2003). "Recycling compartments and the internal vesicles of multivesicular bodies harbor most of the cholesterol found in the endocytic pathway." Traffic 4(4): 222-31.

Mukherjee, S. and F. R. Maxfield (2004). "Lipid and cholesterol trafficking in NPC." Biochim Biophys Acta 1685(1-3): 28-37.

Mukherjee, S., X. Zha, I. Tabas and F. R. Maxfield (1998). "Cholesterol distribution in living cells: fluorescence imaging using dehydroergosterol as a fluorescent cholesterol analog." Biophys J 75(4): 1915-25.

Nandi, S., L. Ma, M. Denis, J. Karwatsky, Z. Li, X. C. Jiang and X. Zha (2009). "ABCA1-mediated cholesterol efflux generates microparticles in addition to HDL through processes governed by membrane rigidity." J Lipid Res 50(3): 456-66.

Oram, J. F. and A. M. Vaughan (2006). "ATP-Binding cassette cholesterol transporters and cardiovascular disease." Circ Res 99(10): 1031-43.

Oram, J. F., R. M. Lawn, M. R. Garvin and D. P. Wade (2000). "ABCA1 is the cAMP-inducible apolipoprotein receptor that mediates cholesterol secretion from macrophages." J Biol Chem 275(44): 34508-11.

Palmer, I. and P. T. Wingfield (2004). "Preparation and extraction of insoluble (inclusion-body) proteins from Escherichia coli." Curr Protoc Protein Sci Chapter 6: Unit 63. 
Panagotopulos, S. E., S. R. Witting, E. M. Horace, D. Y. Hui, J. N. Maiorano and W. S. Davidson (2002). "The role of apolipoprotein A-I helix 10 in apolipoprotein-mediated cholesterol efflux via the ATP-binding cassette transporter ABCA1." J Biol Chem 277(42): 39477-84.

Phillips, J. C., W. Wriggers, Z. Li, A. Jonas and K. Schulten (1997). "Predicting the structure of apolipoprotein A-I in reconstituted high-density lipoprotein disks." Biophys J 73(5): 2337-46.

Phillips, M. C., W. J. Johnson and G. H. Rothblat (1987). "Mechanisms and consequences of cellular cholesterol exchange and transfer." Biochim Biophys Acta 906(2): 223-76.

Price, M. R., F. Hudecz, C. O'Sullivan, R. W. Baldwin, P. M. Edwards and S. J. Tendler (1990). "Immunological and structural features of the protein core of human polymorphic epithelial mucin." Mol Immunol 27(8): 795-802.

Prieto, E. D., N. Ramella, L. A. Cuellar, M. A. Tricerri and H. A. Garda (2012). "Characterization of a human apolipoprotein a-I construct expressed in a bacterial system." Protein J 31(8): 681-8.

Prieto, E. D. and H. A. Garda (2011). "Membrane insertion topology of the central apolipoprotein A-I region. Fluorescence studies using single tryptophan mutants." Biochemistry 50(4): 466-79.

Prinz, W. A. (2007). "Non-vesicular sterol transport in cells." Prog Lipid Res 46(6): 297-314.

Puck, T. T., S. J. Cieciura and H. W. Fisher (1957). "Clonal growth in vitro of human cells with fibroblastic morphology; comparison of growth and genetic characteristics of single epithelioid and fibroblast-like cells from a variety of human organs." J Exp Med 106(1): 145-58. 
Rader, D. J. (2006). "Molecular regulation of HDL metabolism and function: implications for novel therapies." J Clin Invest 116(12): 3090-100.

Ramella, N. A., G. R. Schinella, S. T. Ferreira, E. D. Prieto, M. E. Vela, J. L. Rios, M. A. Tricerri and O. J. Rimoldi (2012). "Human apolipoprotein A-I natural variants: molecular mechanisms underlying amyloidogenic propensity." PLoS One 7(8): e43755.

Rodrigueza, W. V., S. T. Thuahnai, R. E. Temel, S. Lund-Katz, M. C. Phillips and D. L. Williams (1999). "Mechanism of scavenger receptor class B type Imediated selective uptake of cholesteryl esters from high density lipoprotein to adrenal cells." J Biol Chem 274(29): 20344-50.

Rone, M. B., J. Fan and V. Papadopoulos (2009). "Cholesterol transport in steroid biosynthesis: role of protein-protein interactions and implications in disease states." Biochim Biophys Acta 1791(7): 646-58.

Rothblat, G. H., M. de la Llera-Moya, V. Atger, G. Kellner-Weibel, D. L. Williams and M. C. Phillips (1999). "Cell cholesterol efflux: integration of old and new observations provides new insights." J Lipid Res 40(5): 781-96.

Rye, K. A., C. A. Bursill, G. Lambert, F. Tabet and P. J. Barter (2009). "The metabolism and anti-atherogenic properties of HDL." J Lipid Res 50 Suppl: S195-200.

Sambrook J, F. E., Maniatis T. (1989). "Molecular cloning: a laboratory manual."

Sano, O., A. Kobayashi, K. Nagao, K. Kumagai, N. Kioka, K. Hanada, K. Ueda and M. Matsuo (2007). "Sphingomyelin-dependence of cholesterol efflux mediated by ABCG1." J Lipid Res 48(11): 2377-84.

Saraste, J. and B. Goud (2007). "Functional symmetry of endomembranes." Mol Biol Cell 18(4): 1430-6. 
See, R. H., R. A. Caday-Malcolm, R. R. Singaraja, S. Zhou, A. Silverston, M. T. Huber, J. Moran, E. R. James, R. Janoo, J. M. Savill, V. Rigot, L. H. Zhang, M. Wang, G. Chimini, C. L. Wellington, S. R. Tafuri and M. R. Hayden (2002). "Protein kinase A site-specific phosphorylation regulates ATP-binding cassette A1 (ABCA1)-mediated phospholipid efflux." J Biol Chem 277(44): 41835-42.

Segrest, J. P., M. K. Jones, A. E. Klon, C. J. Sheldahl, M. Hellinger, H. De Loof and S. C. Harvey (1999). "A detailed molecular belt model for apolipoprotein A-I in discoidal high density lipoprotein." J Biol Chem 274(45): 31755-8.

Segrest, J. P., M. K. Jones, H. De Loof, C. G. Brouillette, Y. V. Venkatachalapathi and G. M. Anantharamaiah (1992). "The amphipathic helix in the exchangeable apolipoproteins: a review of secondary structure and function." J Lipid Res 33(2): 141-66.

Shibata, N. and C. K. Glass (2010). "Macrophages, oxysterols and atherosclerosis." Circ J 74(10): 2045-51.

Silva, R. A., G. M. Hilliard, L. Li, J. P. Segrest and W. S. Davidson (2005). "A mass spectrometric determination of the conformation of dimeric apolipoprotein A-I in discoidal high density lipoproteins." Biochemistry 44(24): 8600-7.

Simons, K. and D. Toomre (2000). "Lipid rafts and signal transduction." Nat Rev Mol Cell Biol 1(1): 31-9.

Simons, K. and E. Ikonen (1997). "Functional rafts in cell membranes." Nature 387(6633): 569-72.

Singh, R. B., S. A. Mengi, Y. J. Xu, A. S. Arneja and N. S. Dhalla (2002). "Pathogenesis of atherosclerosis: A multifactorial process." Exp Clin Cardiol 7(1): 40-53. 
Smith, J. D., W. Le Goff, M. Settle, G. Brubaker, C. Waelde, A. Horwitz and M. N. Oda (2004). "ABCA1 mediates concurrent cholesterol and phospholipid efflux to apolipoprotein A-I." J Lipid Res 45(4): 635-44.

Suzuki, S., T. Nishimaki-Mogami, N. Tamehiro, K. Inoue, R. Arakawa, S. AbeDohmae, A. R. Tanaka, K. Ueda and S. Yokoyama (2004). "Verapamil increases the apolipoprotein-mediated release of cellular cholesterol by induction of ABCA1 expression via Liver $\mathrm{X}$ receptor-independent mechanism." Arterioscler Thromb Vasc Biol 24(3): 519-25.

Tabas, I. (2002). "Consequences of cellular cholesterol accumulation: basic concepts and physiological implications." J Clin Invest 110(7): 905-11.

Tabas, I. (1997). "Free cholesterol-induced cytotoxicity a possible contributing factor to macrophage foam cell necrosis in advanced atherosclerotic lesions." Trends Cardiovasc Med 7(7): 256-63.

Tazoe, F., H. Yagyu, H. Okazaki, M. Igarashi, K. Eto, S. Nagashima, T. Inaba, H. Shimano, J. Osuga and S. Ishibashi (2008). "Induction of ABCA1 by overexpression of hormone-sensitive lipase in macrophages." Biochem Biophys Res Commun 376(1): 111-5.

Thomas, J. G. and F. Baneyx (1996). "Protein misfolding and inclusion body formation in recombinant Escherichia coli cells overexpressing Heat-shock proteins." J Biol Chem 271(19): 11141-7.

Thuahnai, S. T., S. Lund-Katz, D. L. Williams and M. C. Phillips (2001). "Scavenger receptor class B, type I-mediated uptake of various lipids into cells. Influence of the nature of the donor particle interaction with the receptor." $\mathrm{J}$ Biol Chem 276(47): 43801-8.

Tilly-Kiesi, M., C. J. Packard, J. Kahri, C. Ehnholm, J. Shepherd and M. R. Taskinen (1997). "In vivo metabolism of apo A-I and apo A-II in subjects with 
apo A-I(Lys107-->0) associated with reduced HDL cholesterol and Lp(AI w All) deficiency." Atherosclerosis 128(2): 213-22.

Tilly-Kiesi, M., Q. Zhang, S. Ehnholm, J. Kahri, S. Lahdenpera, C. Ehnholm and M. R. Taskinen (1995). "ApoA-IHelsinki (Lys107-->0) associated with reduced HDL cholesterol and LpA-I:A-II deficiency." Arterioscler Thromb Vasc Biol 15(9): 1294-306.

Toledo, J. D., H. A. Garda, L. V. Cabaleiro, A. Cuellar, M. Pellon-Maison, M. R. Gonzalez-Baro and M. C. Gonzalez (2013). "Apolipoprotein A-I Helsinki promotes intracellular acyl-CoA cholesterol acyltransferase (ACAT) protein accumulation." Mol Cell Biochem 377(1-2): 197-205.

Toledo, J. D., L. V. Cabaleiro, H. A. Garda and M. C. Gonzalez (2012). "Effect of reconstituted discoidal high-density lipoproteins on lipid mobilization in RAW 264.7 and CHOK1 cells." J Cell Biochem 113(4): 1208-16.

Toledo, J. D., E. D. Prieto, M. C. Gonzalez, J. L. Soulages and H. A. Garda (2004). "Functional independence of a peptide with the sequence of human apolipoprotein A-I central region." Arch Biochem Biophys 428(2): 188-97.

Toledo, J. D., M. A. Tricerri, B. Corsico and H. A. Garda (2000). "Cholesterol flux between lipid vesicles and apolipoprotein Al discs of variable size and composition." Arch Biochem Biophys 380(1): 63-70.

Tricerri, M. A., S. A. Sanchez, C. Arnulphi, D. M. Durbin, E. Gratton and A. Jonas (2002). "Interaction of apolipoprotein A-I in three different conformations with palmitoyl oleoyl phosphatidylcholine vesicles." J Lipid Res 43(2): 187-97.

Tricerri, M. A., A. K. Behling Agree, S. A. Sanchez, J. Bronski and A. Jonas (2001). "Arrangement of apolipoprotein A-I in reconstituted high-density lipoprotein disks: an alternative model based on fluorescence resonance energy transfer experiments." Biochemistry 40(16): 5065-74. 
Tricerri, A., B. Corsico, J. D. Toledo, H. A. Garda and R. R. Brenner (1998). "Conformation of apolipoprotein $\mathrm{Al}$ in reconstituted lipoprotein particles and particle-membrane interaction: effect of cholesterol." Biochim Biophys Acta 1391(1): 67-78.

Uittenbogaard, A., Y. Ying and E. J. Smart (1998). "Characterization of a cytosolic heat-shock protein-caveolin chaperone complex. Involvement in cholesterol trafficking." J Biol Chem 273(11): 6525-32.

Ungewickell, E. J. and L. Hinrichsen (2007). "Endocytosis: clathrin-mediated membrane budding." Curr Opin Cell Biol 19(4): 417-25.

Urbani, L. and R. D. Simoni (1990). "Cholesterol and vesicular stomatitis virus $G$ protein take separate routes from the endoplasmic reticulum to the plasma membrane." J Biol Chem 265(4): 1919-23.

Vaughan, A. M. and J. F. Oram (2006). "ABCA1 and ABCG1 or ABCG4 act sequentially to remove cellular cholesterol and generate cholesterol-rich HDL." J Lipid Res 47(11): 2433-43.

Vaughan, A. M. and J. F. Oram (2005). "ABCG1 redistributes cell cholesterol to domains removable by high density lipoprotein but not by lipid-depleted apolipoproteins." J Biol Chem 280(34): 30150-7.

Vedhachalam, C., P. T. Duong, M. Nickel, D. Nguyen, P. Dhanasekaran, H. Saito, G. H. Rothblat, S. Lund-Katz and M. C. Phillips (2007). "Mechanism of ATP-binding cassette transporter A1-mediated cellular lipid efflux to apolipoprotein A-I and formation of high density lipoprotein particles." J Biol Chem 282(34): 25123-30.

Vedhachalam, C., L. Liu, M. Nickel, P. Dhanasekaran, G. M. Anantharamaiah, S. Lund-Katz, G. H. Rothblat and M. C. Phillips (2004). "Influence of ApoA-I structure on the ABCA1-mediated efflux of cellular lipids." J Biol Chem 279(48): 49931-9. 
Wang, X., H. L. Collins, M. Ranalletta, I. V. Fuki, J. T. Billheimer, G. H. Rothblat, A. R. Tall and D. J. Rader (2007). "Macrophage ABCA1 and ABCG1, but not SR-BI, promote macrophage reverse cholesterol transport in vivo." J Clin Invest 117(8): 2216-24.

Wang, N., D. L. Silver, C. Thiele and A. R. Tall (2001). "ATP-binding cassette transporter A1 (ABCA1) functions as a cholesterol efflux regulatory protein." J Biol Chem 276(26): 23742-7.

Warner, G. J., G. Stoudt, M. Bamberger, W. J. Johnson and G. H. Rothblat (1995). "Cell toxicity induced by inhibition of acyl coenzyme A:cholesterol acyltransferase and accumulation of unesterified cholesterol." J Biol Chem 270(11): 5772-8.

Yancey, P. G., A. E. Bortnick, G. Kellner-Weibel, M. de la Llera-Moya, M. C. Phillips and G. H. Rothblat (2003). "Importance of different pathways of cellular cholesterol efflux." Arterioscler Thromb Vasc Biol 23(5): 712-9.

Yu, L., G. Cao, J. Repa and H. Stangl (2004). "Sterol regulation of scavenger receptor class B type I in macrophages." J Lipid Res 45(5): 889-99. 